
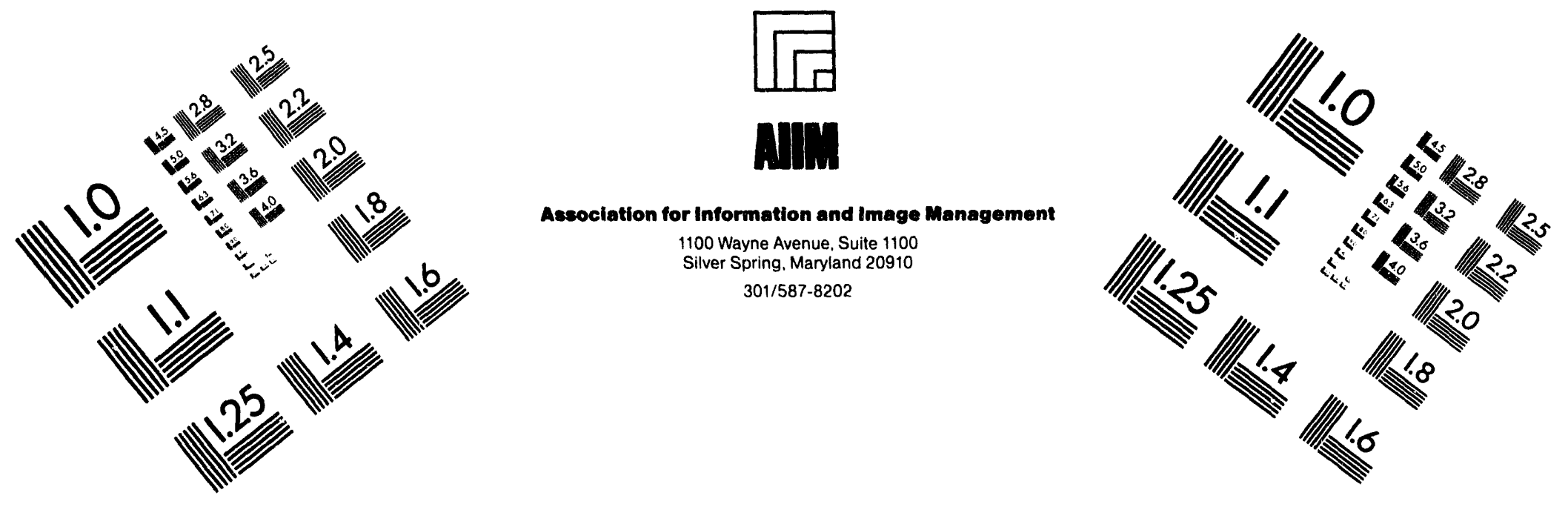

\title{
Centimeter
}

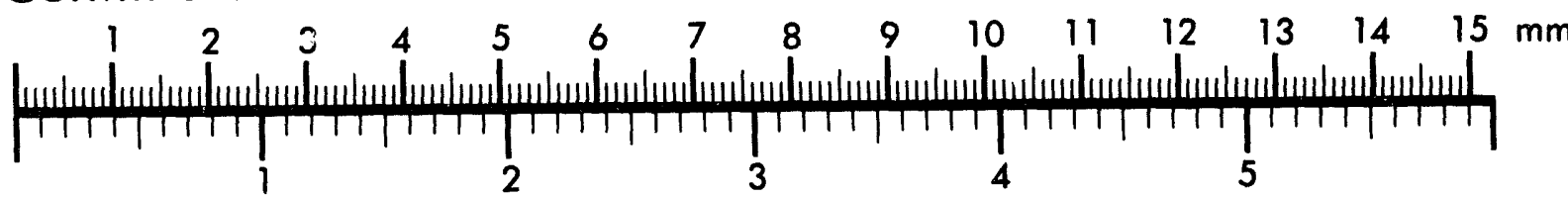
Inches
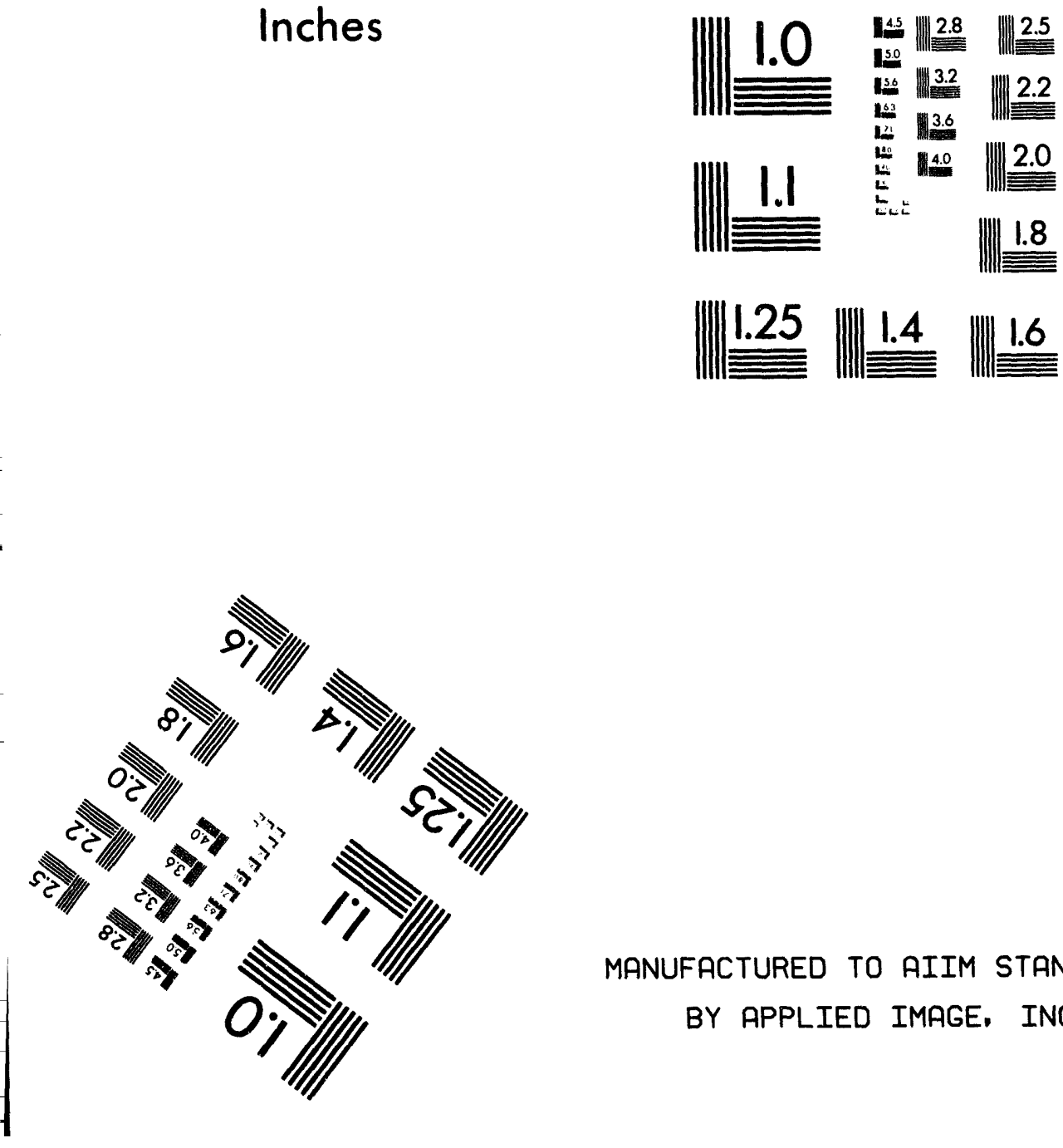

MANUFACTURED TO AIIM STANDARDS

BY APPLIED IMAGE. INC.

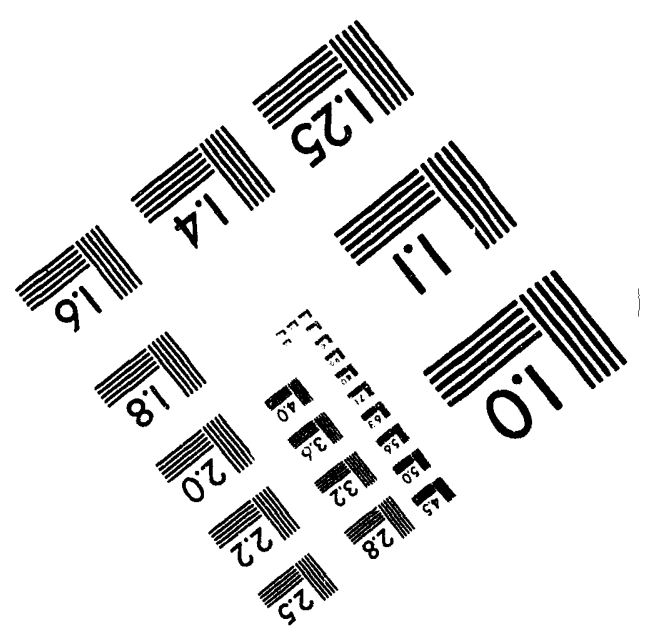



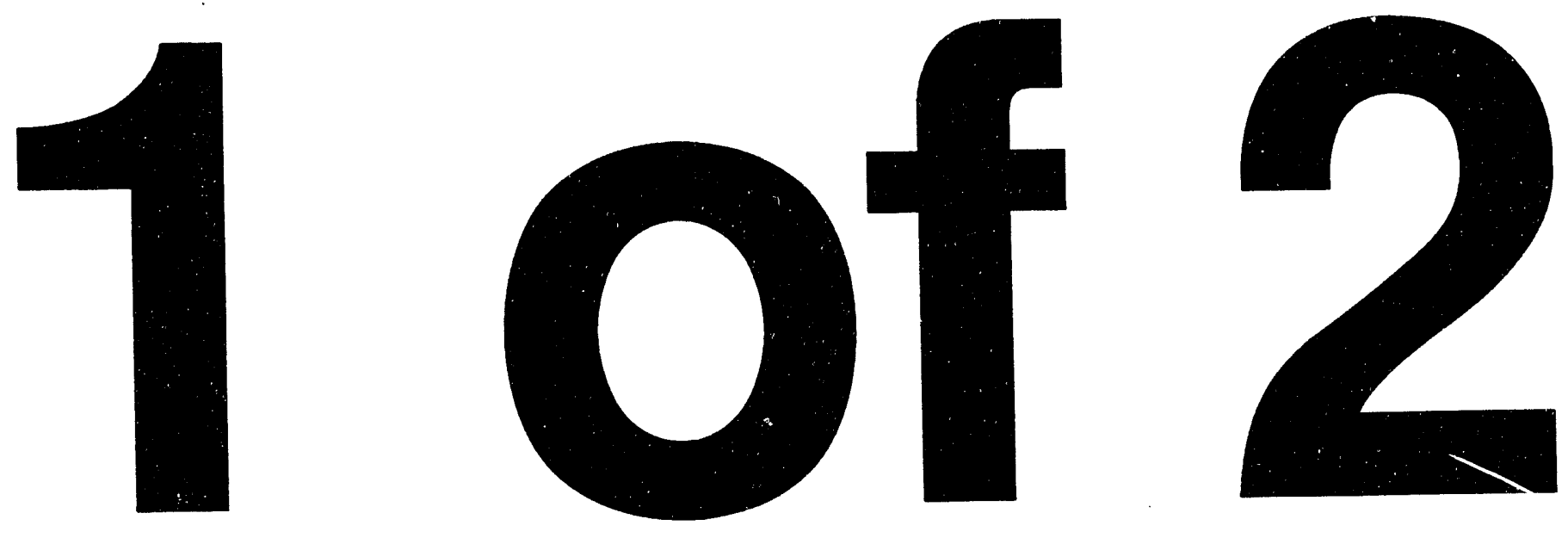
REV. 3

\section{LONG-term SuRVeillance PLAN For the Collins Ranch Disposal Site, LAKEVIEW, OREgon}

August 1994

RECEIVED

SEP 121994

OSTI 


\title{
LONG-TERM SURVEILLANCE PLAN \\ FOR THE COLLINS RANCH DISPOSAL SITE, LAKEVIEW, OREGON
}

August 1994

This document supersedes document number UMTRA-DOE/AL-350213.0000

\author{
Prepared for \\ U.S. Department of Energy \\ UMTRA Project Office \\ Albuquerque, New Mexico \\ Prepared by \\ Jacobs Engineering Group Inc. \\ Albuquerque, New Mexico
}

\section{DISCLAIMER}

\begin{abstract}
This report was prepared as an account of work sponsored by an agency of the United States Government. Neither the United States Government nor any agency thereof, nor any of their employees, makes any warranty, express or implied, or assumes any legal liability or responsibility for the accuracy, completeness, or usefulness of any information, apparatus, product, or process disclosed, or represer ; that its use would not infringe privately owned rights. Reference herein to any specific commercial product, process, or service by trade name, trademark, manufacturer, or otherwise does not necessarily constitute or imply its endorsement, recommendation, or favoring by the United States Government or any agency thereof. The views and opinions of authors expressed herein do not necessarily state or reflect those of the United States Government or any agency thereof.
\end{abstract}


TABLE OF CONTENTS

Section

1.0 INTRODUCTION .............................

1.1 Background $\ldots \ldots \ldots \ldots \ldots \ldots \ldots \ldots \ldots \ldots \ldots \ldots \ldots \ldots \ldots \ldots, 1-1$

1.2 Licensing process $\ldots \ldots \ldots \ldots \ldots \ldots \ldots \ldots \ldots \ldots \ldots \ldots, 1-3$

1.3 Long-term surveillance plan $\ldots \ldots \ldots \ldots \ldots \ldots \ldots \ldots \ldots \ldots, 1-3$

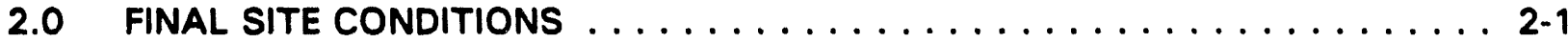

2.1 Site history $\ldots \ldots \ldots \ldots \ldots \ldots \ldots \ldots \ldots \ldots \ldots \ldots \ldots \ldots, 2-1$

2.2 Final site conditions $\ldots \ldots \ldots \ldots \ldots \ldots \ldots \ldots \ldots \ldots \ldots \ldots \ldots \ldots \ldots \ldots \ldots, 2-2$

2.2.1 Description and location of the disposal site area $\ldots \ldots \ldots \ldots .2-2$

2.2.2 Disposal site access and security $\ldots \ldots \ldots \ldots \ldots \ldots \ldots .2-4$

2.2.3 Disposal cell design ..................... 2-5

3.0 SITE DRAWINGS AND PHOTOGRAPHS $\ldots \ldots \ldots \ldots \ldots \ldots \ldots \ldots \ldots$ 3-1

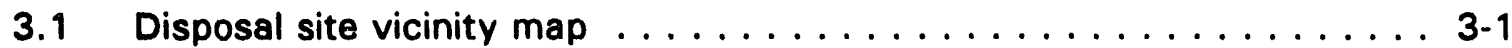

3.2 Disposal site topographic $\operatorname{map} \ldots \ldots \ldots \ldots \ldots \ldots \ldots \ldots \ldots, 3-1$

3.3 Disposal site as-built drawings $\ldots \ldots \ldots \ldots \ldots \ldots \ldots \ldots \ldots, 3-2$

3.4 Site baseline photographs $\ldots \ldots \ldots \ldots \ldots \ldots \ldots \ldots \ldots \ldots, 3_{3-2}$

3.5 Site aerial photographs $\ldots \ldots \ldots \ldots \ldots \ldots \ldots \ldots \ldots \ldots \ldots \ldots, \ldots \ldots$

3.6 Site inspection photographs $\ldots \ldots \ldots \ldots \ldots \ldots \ldots \ldots \ldots, 3$

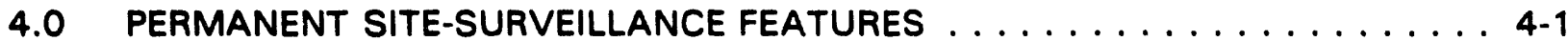

4.1 Survey monuments $\ldots \ldots \ldots \ldots \ldots \ldots \ldots \ldots \ldots \ldots \ldots, \ldots \ldots \ldots$

4.2 Boundary monuments $\ldots \ldots \ldots \ldots \ldots \ldots \ldots \ldots \ldots \ldots \ldots, \ldots \ldots \ldots$

4.3 Site markers $\ldots \ldots \ldots \ldots \ldots \ldots \ldots \ldots \ldots \ldots \ldots \ldots \ldots, 4,1$

4.4 Entrance and perimeter signs $\ldots \ldots \ldots \ldots \ldots \ldots \ldots \ldots \ldots, 4.7$

4.5 Settlement plates $\ldots \ldots \ldots \ldots \ldots \ldots \ldots \ldots \ldots \ldots \ldots \ldots$ 4.7

5.0 GROUND WATER MONITORING $\ldots \ldots \ldots \ldots \ldots \ldots \ldots \ldots \ldots \ldots$ 5-1

5.1 Ground water characterization $\ldots \ldots \ldots \ldots \ldots \ldots \ldots \ldots \ldots \ldots, 5,1$

5.1.1 Hydrostratigraphy $\ldots \ldots \ldots \ldots \ldots \ldots \ldots \ldots \ldots \ldots, 5,3$

5.1 .2 Background ground water quality ............. 5-4

5.1.3 Monitored constituents and concentration limits . . . . . . . . . 5-4

5.2 Ground water monitoring network $\ldots \ldots \ldots \ldots \ldots \ldots \ldots \ldots, 5.8$

5.2.1 Direct monitoring network .................. 5-8

5.2.2 Monitor well installation and development . . . . . . . . 5-10

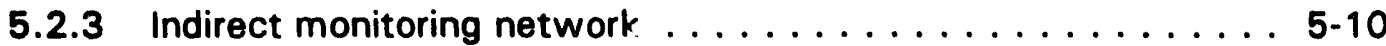

5.3 Ground water monitoring program $\ldots \ldots \ldots \ldots \ldots \ldots \ldots \ldots, 5-10$

5.3.1 Sampling frequency $\ldots \ldots \ldots \ldots \ldots \ldots \ldots \ldots \ldots . . \ldots$ 5-11

5.3.2 Screening monitoring and exceedance validation $\ldots \ldots \ldots .5-13$

5.3.3 Evaluative monitoring $\ldots \ldots \ldots \ldots \ldots \ldots \ldots \ldots \ldots .5 .14$

5.3.4 Indirect monitoring $\ldots \ldots \ldots \ldots \ldots \ldots \ldots \ldots \ldots \ldots, 5-14$

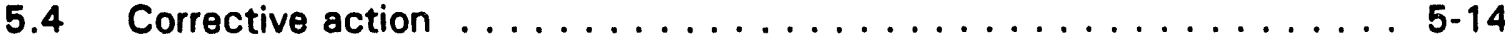

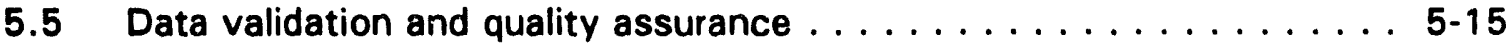

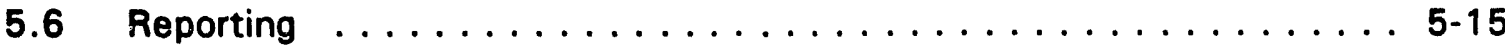




\section{TABLE OF CONTENTS (Continued)}

Section

Page

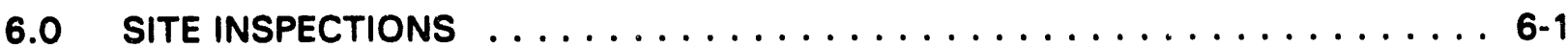

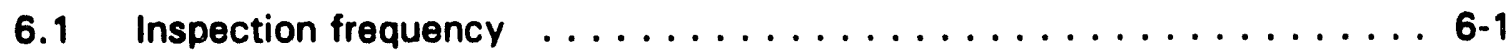

6.2 Inspection team ......................... $6 . \ldots$

6.3 Preparation for inspection .................... 6-2

6.4 Site inspection and inspection checklist $\ldots \ldots \ldots \ldots \ldots \ldots \ldots \ldots \ldots$

6.4.1 Off-site areas . . . . . . . . . . . . . . . . . . 6. 6-3

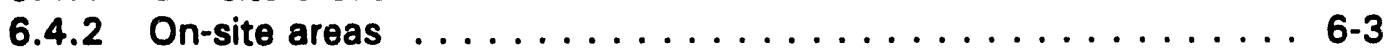

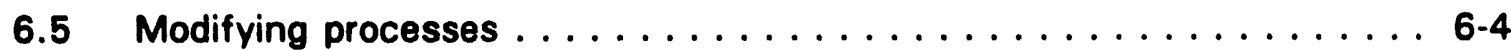

6.6 Vegetation .......................... 6.5

6.6.1 Planned vegetation ................... 6-5

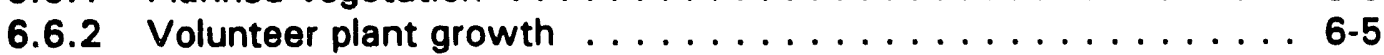

6.7 Site inspection map ...................... 6.5

6.8 Reporting requirements . . . . . . . . . . . . . . . 6-6

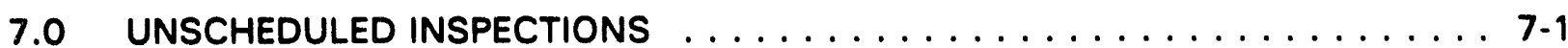

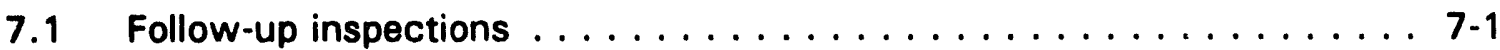

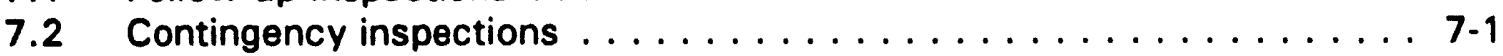

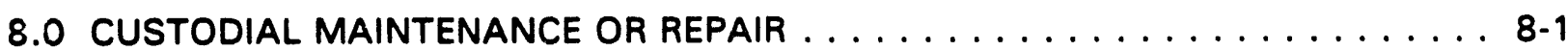

8.1 Planned maintenance $\ldots \ldots \ldots \ldots \ldots \ldots \ldots \ldots \ldots \ldots$ 8.1

8.2 Unscheduled maintenance or repair $\ldots \ldots \ldots \ldots \ldots \ldots \ldots \ldots$ 8-1

8.3 Certification and reporting requirements $\ldots \ldots \ldots \ldots \ldots \ldots$

9.0 CORRECTIVE ACTION $\ldots \ldots \ldots \ldots \ldots \ldots \ldots \ldots \ldots \ldots \ldots \ldots \ldots$

9.1 Problem identification . . . . . . . . . . . . . . . . . 9-4

9.2 Certification and reporting procedures $\ldots \ldots \ldots \ldots \ldots \ldots$

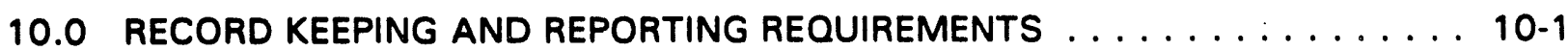

10.1 Records ............................. 10-1

10.2 Reports ............................ 10-3

11.0 EMERGENCY NOTIFICATION AND REPORTING $\ldots \ldots \ldots \ldots \ldots \ldots \ldots \ldots$

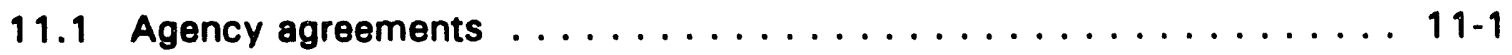

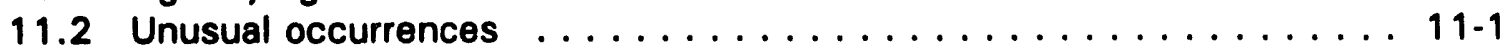

11.3 Earthquakes .......................... 11-1

11.4 Meteorological events ...................... 11-2

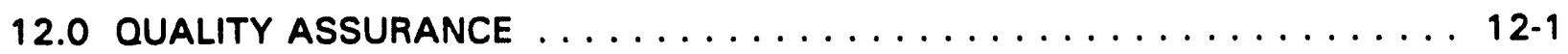

13.0 PERSONNEL HEALTH AND SAFETY $\ldots \ldots \ldots \ldots \ldots \ldots \ldots \ldots \ldots \ldots \ldots \ldots \ldots$

13.1 Health and safety ...................... 13-1

13.2 Reportable incidents ........................ 13-2 
TABLE OF CONTENTS (Continued)

Section

Page

14.0 LIST OF CONTRIBUTORS $\ldots \ldots \ldots \ldots \ldots \ldots \ldots \ldots \ldots \ldots \ldots \ldots$

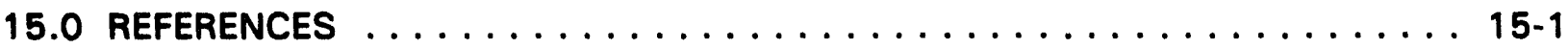

ATTACHMENT 1 SITE OWNERSHIP/CUSTODY DOCUMENTATION

ATTACHMENT 2 NRC CONCURRENCE AND LICENSING DOCUMENTATION

ATTACHMENT 3 LAKEVIEW PERMANENT SITE FILE INDEX

ATTACHMENT 4 SITE INSPECTION PHOTO LOG

ATTACHMENT 5 SUPPORTING DOCUMENTATION

ATTACHMENT 6 SITE INSPECTION CHECKLIST

ATTACHMENT 7 AGENCY NOTIFICATION AGREEMENTS 


\section{LIST OF FIGURES}

Fiqure

Page

1.1 Location of Collins Ranch disposal site, Lakeview, Oregon . . . . . . . . . . . 1-2

2.1 Location of the Collins Ranch disposal site $\ldots \ldots \ldots \ldots \ldots \ldots \ldots \ldots$

2.2 Final condition - Collins Ranch disposal site . . . . . . . . . . . . . 2-6

2.3 Typical cross section - Collins Ranch disposal site . . . . . . . . . . 2-7

2.4 Topslopes cover system - Collins Ranch disposal site . . . . . . . . . . 2-8

4.1 UMTRA Project survey monument - Collins Ranch disposal site . . . . . . . . 4-2

4.2 UMTRA Project boundary monument - Collins Ranch disposal site . . . . . . 4 4-3

4.3 UMTRA Project entrance site marker - Collins Ranch disposal site . . . . . . . 4-4

4.4 UMTRA Project site marker at crest of disposal cell - Collins Ranch disposal site . . . . . . . . . . . . . . . . . . . . . . . 4-5

4.5 UMTRA Project site marker incised message - Collins Ranch disposal site . . 4-6

4.6 UMTRA Project entrance sign and message - Collins Ranch disposal site . . . 4-8

4.7 UMTRA Project perimeter sign and message - Collins Ranch disposal site . . 4-9

4.8 UMTRA Project settlement plates - Collins Ranch disposal site . . . . . . . 4-10

5.1 September 1992 water table contour map of the Collins Ranch disposal site . . 5-2

5.2 Location of excavation wall seeps during construction - Collins Ranch

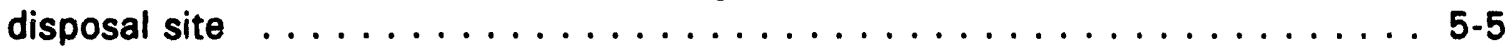

5.3 Monitor well locations - Collins Ranch disposal site . . . . . . . . . . . 5 5-9

5.4 UMTRA Project ground water monitoring program . . . . . . . . . . 5-12

9.1 Corrective action-UMTRA Project long-term surveillance program . . . . . . 9-2

9.2 Key elements in the corrective action process $\ldots \ldots \ldots \ldots \ldots \ldots \ldots$

\section{LIST OF PLATES}

$1 \quad$ Collins Ranch disposal vicinity site map

2 Collins Ranch final disposal site final topographic map 


\section{LIST OF TABLES}

Table

Page

2.1 Collins Ranch disposal site key holders . . . . . . . . . . . . . . . . 2-4

3.1 Aerial photography specifications for the Collins Ranch

disposal site ............................ 3-4

5.1 Maximum concentration limits for ground water protection . . . . . . . . 5-6

5.2 Summary of hazardous constituents identified in the Lakeview tailings pore fluid, maximum background, POC wells, and proposed EPA MCLs . . . . . 5-6

5.3 List of constituents recommended for long-term monitoring at the Collins Ranch disposal site 


\section{LIST OF ACRONYMS AND ABBREVIATIONS}

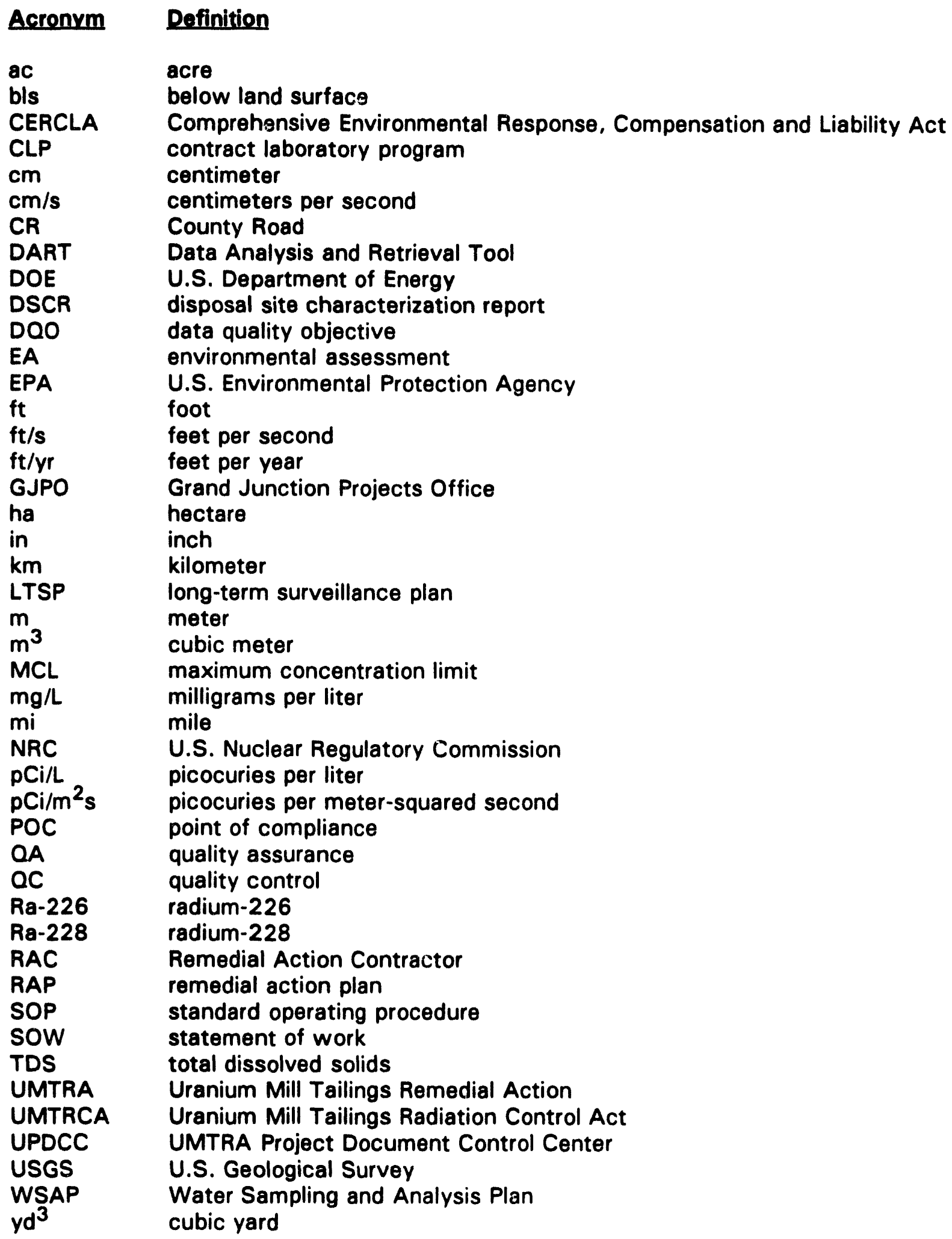




\subsection{INTRODUCTION}

This long-term surveillance plan (LTSP) for the Uranium Mill Tailings Remedial Action (UMTRA) Project Collins Ranch disposal site, Lakeview, Oregon, describes the surveillance activities for the disposal cell. The U.S. Department of Energy (DOE) will carry out these activities to ensure that the disposal cell continues to function as designed. This final LTSP was prepared as a requirement for acceptance under the U.S. Nuclear Regulatory Commission (NRC) general license for custody and long-term care of residual radioactive materials. This LTSP documents whether the land and interests are owned by the United States and details how long-term care of the disposal site will be carried out. It is based on the DOE's Guidance for Implementing the UMTRA Project Long-term Surveillance Program (DOE, 1992a).

\subsection{BACKGROUND}

Title I of the Uranium Mill Tailings Radiation Control Act (UMTRCA) of 1978 (42 USC \$7901) authorized the DOE to perform remedial action at 24 inactive uranium mill tailings processing sites to reduce the potential effect on public health from the unstabilized residual radioactive materials in and around the uranium mill tailings. The Lakeview, Oregon, uranium mill tailings processing site in Lake County was one of the 24 sites identified for remediation in the UMTRCA. The DOE, NRC, and the state of Oregon entered into a cooperative agreement under the UMTRCA, establishing terms and conditions of the remedial action (DOE Cooperative Agreement No. DE-FC04-84AL20534), November 26, 1984. A remedial action that satisfied UMTRCA program requirements was proposed for the processing site and was completed in October 1989. During remedial action, $736,00 \mathrm{r}$ tons $(667,700$ tonnes) of dry mill tailings were relocated to a permanent disposal site located approximately 7 miles (mi) (11 kilometers [ $\mathrm{km}$ ]) north of the processing site and the town of Lakeview, Oregon, in Township 38 South, Range 19 East (T38S, R19E), in Section 12, Willamette Meridian (DOE, 1992b; 1985a). Figure 1.1 shows the general location of the Collins Ranch disposal site, Lakeview, Oregon. The NRC and the state of Oregon concurred with the DOE's remedial action plan (RAP) (DOE, 1992b) to comply with the requirements of the U.S. Environmental Protection Agency's (EPA) standards in 40 CFR 192 and proposed standards in 52 FR 36000 . The Subpart $A$ and $C$ remedial action was described and evaluated in an environmental assessment (EA) (DOE, 1985a) prepared by the DOE. Ground Water Compliance Program activities at the processing site will be implemented at a later date. No ground water compliance activities will apply to the disposal site because the uranium mill tailings were relocated away from the processing site. However, ground water monitoring activities to monitor disposal cell performance are part of this LTSP and are required to license the disposal site. 


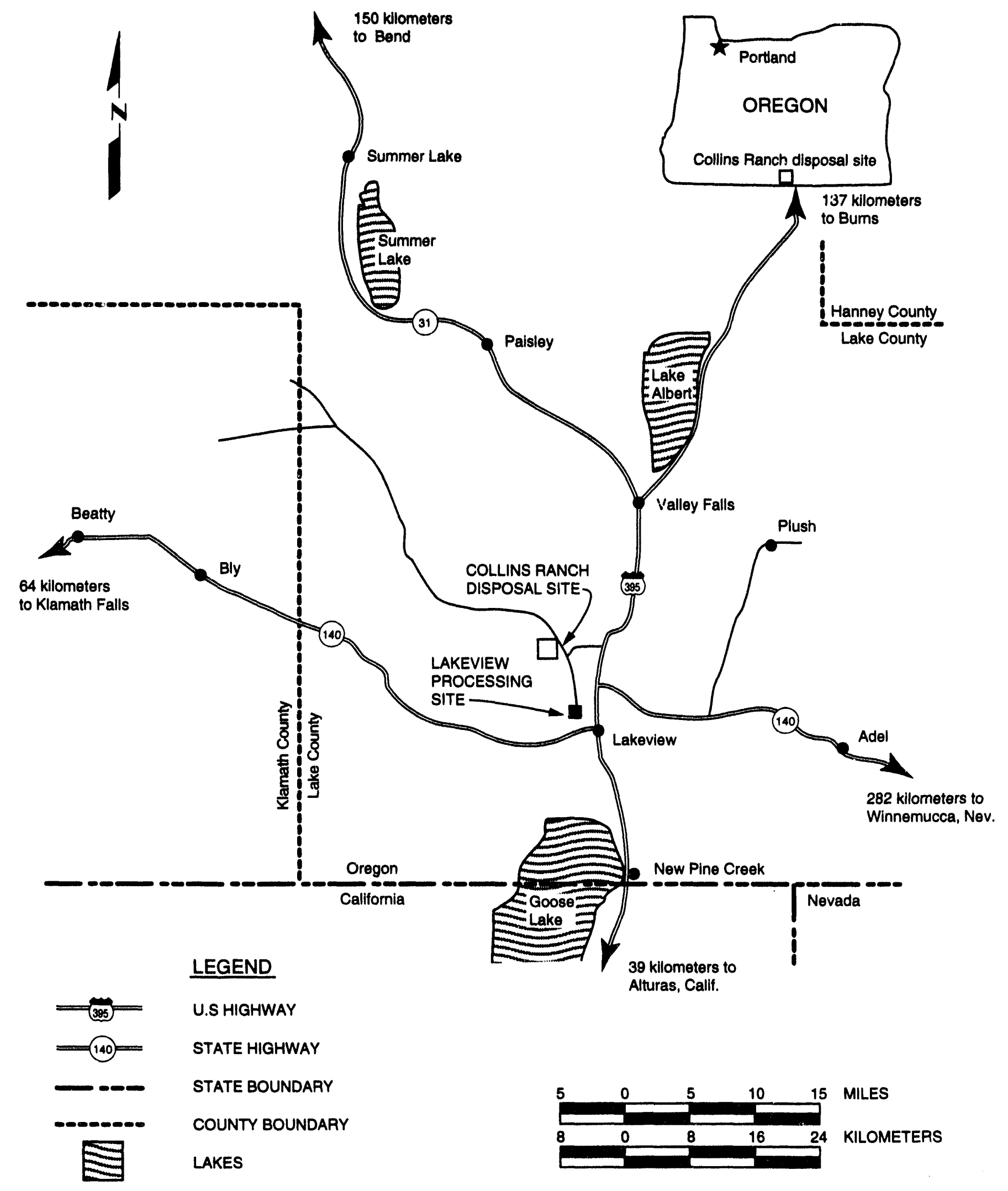

FIGURE 1.1

LOCATION OF COLLINS RANCH DISPOSAL SITE, LAKEVIEW, OREGON 


\subsection{LICENSING PROCESS}

The NRC has developed regulations 10 CFR 40.27 (effective November 29, 1990 [55 FR 45591]) for the issuance of a general license for the long-term care of DOE UMTRA (Title I) disposal sites, including tha Collins Ranch disposal site. The license is available only to the DOE (or any successor federal agency designated by the President) and has no termination date. The purpose of this general license is to ensure that the UMTRA disposal sites will be cared for in a manner that protects the public health and safety and the environment after the NRC, State, and DOE concur that the remedial action is complete at that site (i.e., acceptance of the site-specific completion report and certification summary) and formally accepts the site-specific L TSP that meets the requirements of 10 CFR 40.27. The site-specific completion report documents the site as-built conditions. The DOE prepares a certification summary memorandum certifying satisfaction of approved RAP provisions and compliance with EPA standards. The DOE compiles the final completion report, final audit report, and certification summary into the certification report and submits it to the NRC and state for concurrence (DOE, 1993).

\section{Acquisition}

The Collins Ranch disposal site was acquired by the state of Oregon through a civil action suit (Lake County Circuit Case No. L-86-060-CV, File No. 330-050-TL001-86, state of Oregon, by and through the Energy Facility Siting Counsel $v$ John Collins, et al.). Final disposition of the case provided a 40-acre (ac) (16-hectare (ha]) disposal site in fee with perpetual access leading west from County Road (CR) 2-16B across the Collins Ranch to the disposal area. For additional information see Attachment 1 , which provides a legal description of the Collins Ranch disposal site and documents the transfer of title of the disposal cell area to the DOE for long-term care and ownership.

\subsection{LONG-TERM SURVEILLANCE PLAN}

This document describes the long-term surveillance program to be implemented at the Collins Ranch disposal site to ensure that the disposal cell continues to perform as designed. This plan is based on the DOE's Guidance for Implementing the UMTRA Project Long-term Surveillance Program (DOE, 1992a).

This LTSP meots the requirements under 10 CFR 40.27 by addressing the following:

- Site description and ownership.

- Description of final site conditions.

- Site inspection procedures and personnel.

- Custodial maintenance and corrective actions programs. 
LONG.TERM SUAVEILLANCE PLAN FOA THE COLLLNS

RANCH DISPOSAL SITE. LAKEVIEW. OREOON

- Record keeping and reporting.

- Quality assurance (QA).

- Emergency response. 


\subsection{FINAL SITE CONDITIONS}

\section{1}

\section{SITE HISTORY}

The Lakeview uranium processing mill was constructed by the Lakeview Mining Company in 1958 and began operating the same year. The owners of this firm also owned the Gunnison Mining Company, which operated the mill at Gunnison, Colorado. Both companies were acquired in 1961 by Kerr-McGee Oil Industries through its subsidiary, Kermac Nuclear Fuels Corporation. Between 1960 and 1968, the property had five owners (DOE, 1992b).

During the 1958 to 1961 period of operation, 130,000 tons (120,000 tonnes) of ore were treated at the mill site. The mill operated at a rated capacity of 210 tons (190 tonnes) of ore per day and used a sodium chlorate and sulfuric acid leach process. Ore for processing came from the White King and Lucky Lass mines, approximately 16 road $\mathrm{mi}(26 \mathrm{~km})$ northwest of Lakeview (DOE, 1992b).

In 1968, the Lakeview site was acquired by Atlantic Richfield Company. In 1974, Atlantic Richfield initiated and subsequently performed a cleanup operation on the site under a plan approved by the Oregon State Health Division. By 1977, the mill buildings and immediate surroundings had been decontaminated to meet the then-existing requirements of the Oregon regulations for the control of radiation. The property was sold on March 8, 1978, to Precision Pine Lumber Company, which used the site and structures as a lumber mill and stockpile for sawdust and scrap waste. The property containing the mill buildings, office area, and acreage for timber storage was sold to Goose Lake Lumber Company in 1987. Precision Pine Lumber Company still retains title to the former tailings pile area (DOE, 1992b).

The Lakeview site was designated for remedial action by the UMTRCA in November 1978. On September 8, 1986, remedial action began at the Lakeview processing mill. During the next three years, 926,000 cubic yards $\left(\mathrm{yd}^{3}\right)\left(708,000\right.$ cubic meters $\left.\left[\mathrm{m}^{3}\right]\right)$ of contaminated materials from the tailings pile, evaporation ponds, windblown and waterborne deposit areas, and windblown contaminated areas dispersed around the processing site were relocated to a permanent disposal site, the Collins Ranch disposal site approximately $7 \mathrm{mi}(11 \mathrm{~km})$ north of Lakeview, Oregon. Approximately 736,000 tons (667,700 tonnes) of these contaminated materials are classified as tailings. Remedial action at the processing site was completed in October 1989. The relocated contaminated materials were stabilized in a disposal cell covering an area of approximately 16 ac (6.5 ha) within a 40-ac (16-ha) disposal site (DOE, 1992C). NRC concurrence on the RAP was received on June 12, 1992 (Attachment 2). The NRC concurred on the DOE's completion report and certification summary in September 1993 (Attachment 2). 
When the general license becomes effective, following acceptance of the LTSP, responsibility for the long-term surveillance program will be transferred to the DOE Grand Junction Projects Office (GJPO), Grand Junction, Colorado. The programmatic transfer will occur within 30 days of NRC notification that the license is in effect. The DOE remains the responsible federal agency uriess a successor agency is designated by the President of the United States.

\subsection{FINAL SITE CONDITIONS}

\subsubsection{Description and location of the disposal site area}

The Collins Ranch disposal site is located in Lake County, Oregon, T38S, R19E, Section 12, Willamette Meridian, approximately $7 \mathrm{mi}(11 \mathrm{~km})$ north of Lakeview, Oregon (Figure 2.1) (DOE, 1985a; 1992b).

The disposal site area is situated near the northern end of Goose Lake Valley, a large flat mountain valley at an elevation of 4750 feet (ft) (1450 meters [m]) above sea level. Mountain peaks in surrounding ranges to the east and west are in the Fremont National Forest and reach elevations of more than $8000 \mathrm{ft}$ $(2400 \mathrm{~m})$ above sea level. Many lakes are in the general area; the largest is Goose Lake, located about $17 \mathrm{mi}(27 \mathrm{~km})$ south of the disposal site. Vegetation consists of pine cover in the higher mountain areas with trees, sage, and scrub brush in the foothills. The valleys are grassy meadows and are used primarily as grazing land (FBD, 1977; DOE, 1985a).

The Collins Ranch disposal site is located in part of Oregon's semiarid or high desert country. The area is characterized by cool temperatures and moderate southerly winds. The average annual precipitation in the area is 16 inches (in) (410 millimeters [mm]) and is spread fairly evenly throughout 9 months of the year. Less than 6 percent of the annual precipitation occurs during the summer months (FBD, 1977).

No plant species listed as endangered or threatened are found on or near the Collins Ranch disposal site. No buildings or structures in the immediate vicinity of the disposal site are listed on, or are eligible for listing on, the National Register of Historic Places. No significant cultural finds were identified on the Collins Ranch disposal site, although adjacent to the site obsidian flakes and obsidian projectile points were reported as isolated finds. Figure 1.1 provides a map of the Lakeview area.

The Lakeview site can be accessed by following these directions:

Starting in the center of the Lakeview commercial district, at the junction of State Route 140 and U.S. Route 395

- Proceed north on U.S. 395 for $6.4 \mathrm{mi}(10.3 \mathrm{~km})$.

- Turn west on County Road (CR) 2-16.

- Proceed west on CR 2-16 for $3.3 \mathrm{mi}(5.3 \mathrm{~km})$. 


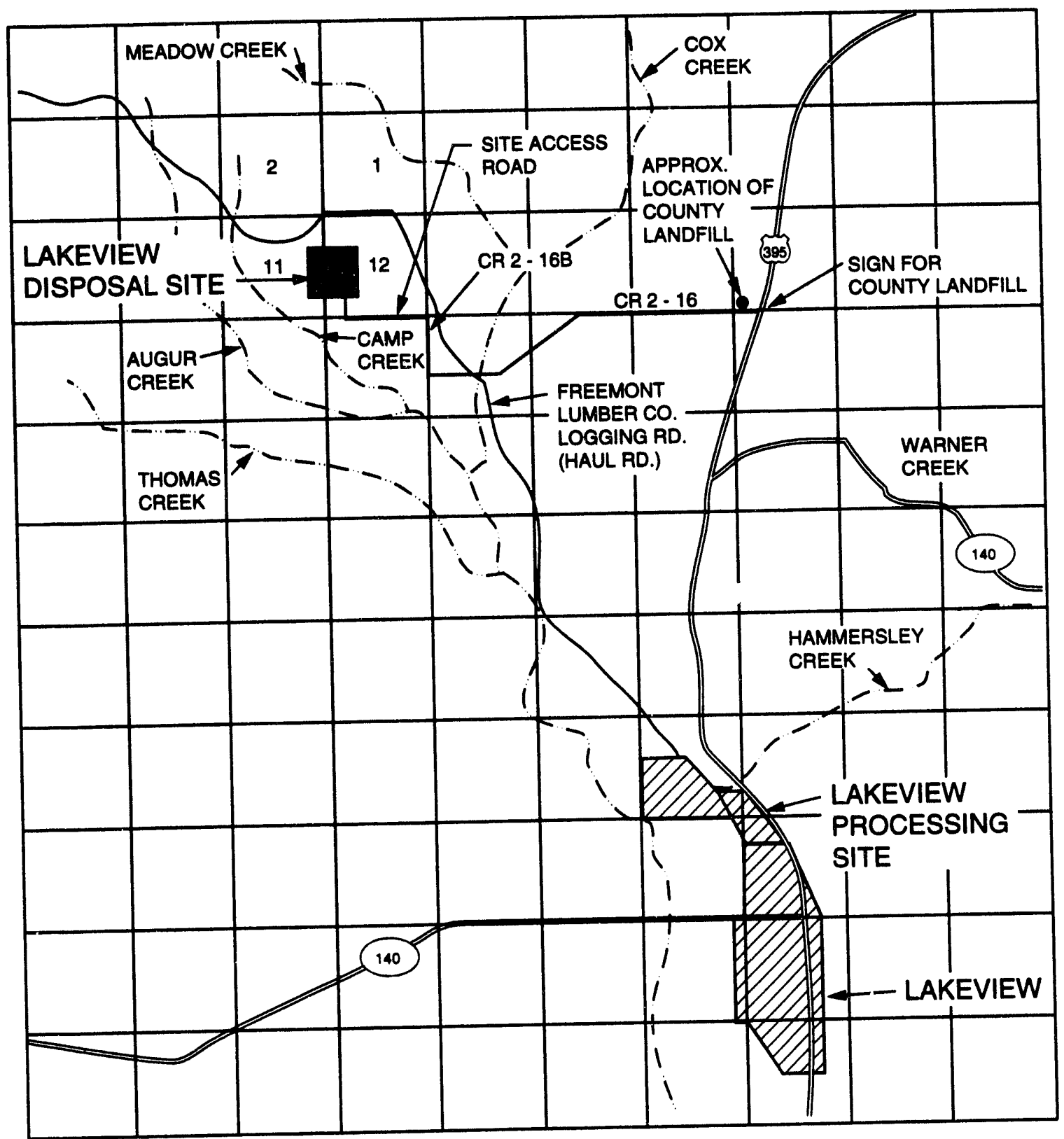

REF: DOE, 1992b

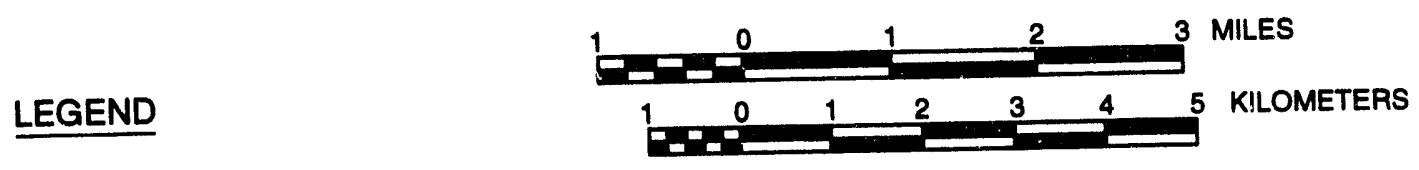

COLLINS RANCH DISPOSAL SITE

LAKEVIEW PROCESSING SITE

(140) STATE HIGHWAY

(395) U.S. HIGHWAY

LOGGING ROAD

-..- ePHEMERAL STREAM

FIGURE 2.1

LOCATION OF THE COLLINS RANCH DISPOSAL SITE 
- Turn north on CR 2-16B.

- Proceed north on CR 2-16B for $0.5 \mathrm{mi}(0.8 \mathrm{~km})$.

- Turn west onto the site access road.

- Proceed $1.4 \mathrm{mi}(2.2 \mathrm{~km})$, then bear right to the site entrance.

The land surrounding the Collins Ranch disposal site is privately owned. The current owners are John and Bridget Collins. The land is zoned A-2 (agricultural use) and is used for livestock grazing. The nearest inhabited structure is approximately $1 \mathrm{mi}(1.6 \mathrm{~km})$ from the site.

\subsubsection{Disposal site access and security}

No prior notification or permission is necessary for the DOE to access the Collins Ranch disposal site or any of the on-site or off-site ground water monitoring wells. Civil action suit, Lake County Circuit Court Case No. L-86-060-CV, File No. 330-050-TL001-86, provided a 40-ac (16-ha) disposal site in fee with perpetual access leading west from CR 2-16B across the Collins Ranch to the disposal area, as well as unlimited access to all off-site ground water monitoring wells.

Keys to the Collins Ranch disposal site are maintained by the DOE UMTRA Project Manager, the Technical Assistance Contractor (TAC) UMTRA Project Manager, and the supervisory general engineer, GJPO (Table 2.1).

Table 2.1 Collins Ranch disposal site key holders

\begin{tabular}{|c|c|c|}
\hline Title and current contact & Telephone & Address \\
\hline DOE UMTRA Project Manager & (505) 845-4022 & $\begin{array}{l}\text { U.S. Department of Energy } \\
\text { UMTRA Project Office } \\
2155 \text { Louisiana NE, Suite } 4000 \\
\text { Albuquerque, NM } 87110\end{array}$ \\
\hline TAC UMTRA Project Manager & $(505) 888-1300$ & $\begin{array}{l}\text { Jacobs Engineering Group Inc. } \\
2155 \text { Louisiana NE, Suite } 10,000 \\
\text { Albuquerque, NM } 87110\end{array}$ \\
\hline GJPO supervisory general engineer & (303) 248-6006 & $\begin{array}{l}2597 \text { B } 3 / 4 \text { Road } \\
\text { Grand Junction, CO } 81503\end{array}$ \\
\hline
\end{tabular}

The Collins Ranch disposal site is located approximately $7 \mathrm{mi}(11 \mathrm{~km})$ north of the town of Lakeview, Oregon, in an undeveloped and remote area. The site is not visible from the main highway. A barbed-wire stock fence with one locked entrance gate surrounds the adjacent ranch land and the disposal cell. Warning signs are posted at locations around the site $(1$ at the entrance and 11 around the perimeter) to inform the public of the site's function and ownership (Section 4.4). 
Because of the remote location of the disposal site, purposeful intrusion is not expected to be a problem. However, if intrusion, vandalism, or other factors (e.g.. grazing) become a problem, site security will be reevaluated.

The effectiveness of these security measures wil! be monitored through scheduled site inspections (Section 6.4). A DOE 24-hour telephone number on the entrance sign (Section 4.4) and agreements with local agencies to notify the DOE in the event of an emergency or breach of site integrity (Section 11.0) provide additional security measures.

\subsubsection{Disposal cell desion}

The tailings embankment at the Collins Ranch disposal site is constructed partially belowgrade, against the southwest slope of Augur Hill. The embankment contains $926,000 \mathrm{yd}^{3}\left(708,000 \mathrm{~m}^{3}\right)$ of contaminated material and covers approximately 16 ac $(6.5 \mathrm{hal}$; maximum dimensions are $1050 \times 800 \mathrm{ft}$ $(320 \times 240 \mathrm{~m})$. A drainage ditch at the northern edge of the disposal cell directs runoff water away from the site (Figure 2.2). Plan and cross-section views of the Collins Ranch disposal cell are presented in Figures 2.2 and 2.3 (DOE, 1992b).

The radon emanation rate from the disposal cell was reduced to less than the EPA standard of 20 picocuries per meter-squared second $\left(\mathrm{pCi} / \mathrm{m}^{2} \mathrm{~s}\right.$ ) ( 0.74 becquerels per meter-squared second) by encapsulating the tailings with a compacted $1.5-\mathrm{ft}(0.5-\mathrm{m})$-thick radon barrier layer of uncontaminated silt and clay. The radon barrier thickness is based on information obtained during construction to provide the optimum design. The radon barrier is protected by a 1-ft $(310-\mathrm{mm})$-thick layer of rock and a 6 in $(150 \mathrm{~mm})$, highly conductive filter layer on all sides, and a rock-soil matrix on the topslope. The highly conductive filter layer protects the fine-grained soils of the radon barrier from piping and erosion and at the same time quickly sheds water from the pile surface. Both the rock layer (sideslopes) and rock-soil layer (topslopes) were designed to protect the radon barrier from erosion for 1000 years and thus prevent exposure of contaminated materials. The rock and rock-soil cover also prevents erosion caused by water flowing on or adjacent to the pile, protects the embankment from wind erosion, and discourages burrowing animals. In addition to the rocksoil layer, the disposal cell topslope is covered with a native grass. The cover system for the embankment topslope is illustrated in Figure 2.4.

The drainage features of the embankment and general site grading ensure long-term embankment stability. The embankment sideslopes blend into the natural slopes south of Augur Hill. Runoff from the embankment flows to the apron and then to the adjacent natural ground (modified by grading to inhibit gully formation) and then to the natural drainage patterns southwest of the site. Runoff from Augur Hill is intercepted by a drainage ditch located adjacent to the embankment and directed to the natural drainage patterns southeast of the site. The ditch has sufficient depth to carry the runoff from a probable maximum precipitation storm event. Rock erosion protection in the ditch prevents erosion 


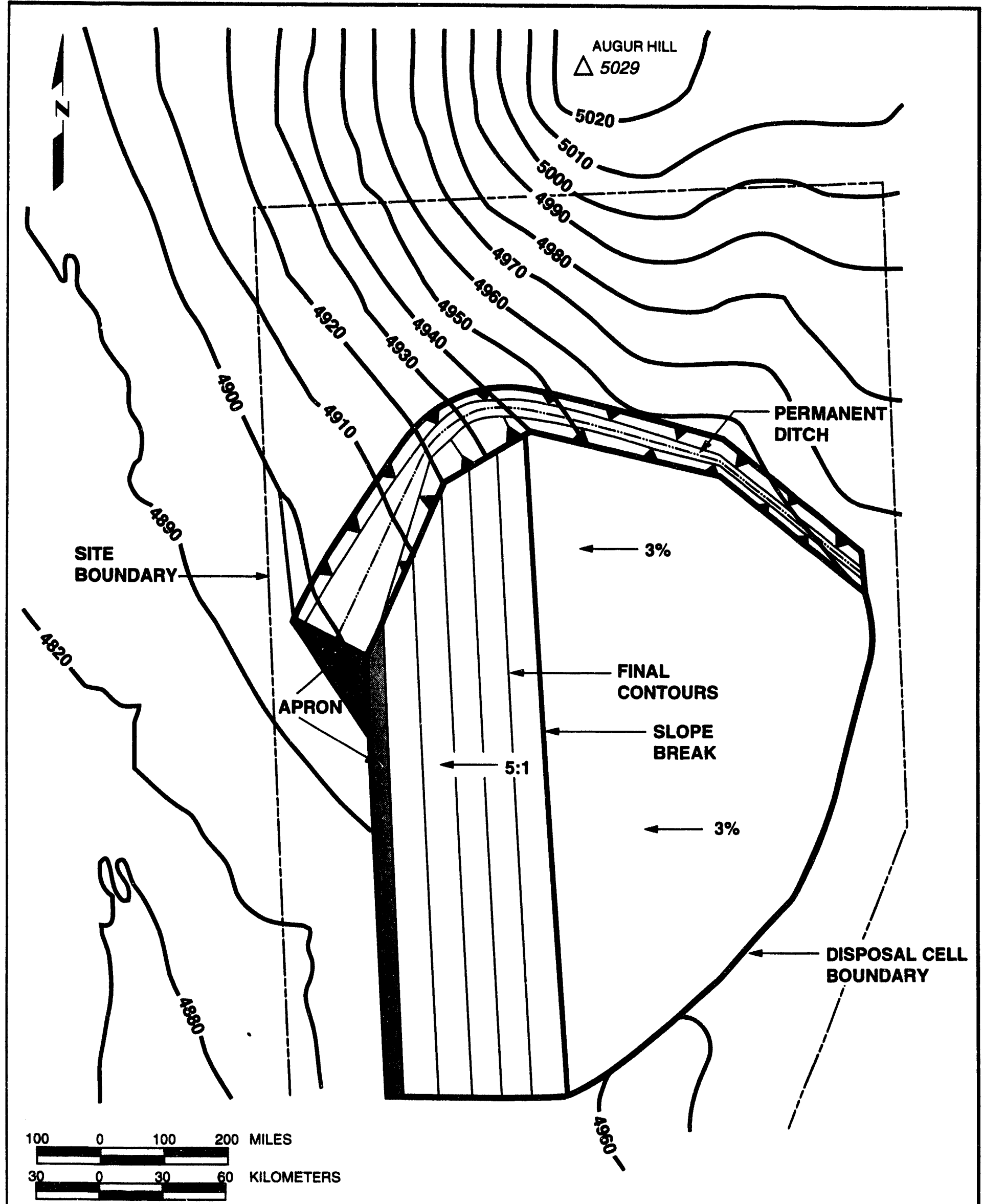

FIGURE 2.2

FINAL CONDITION - COLLINS RANCH DISPOSAL SITE 


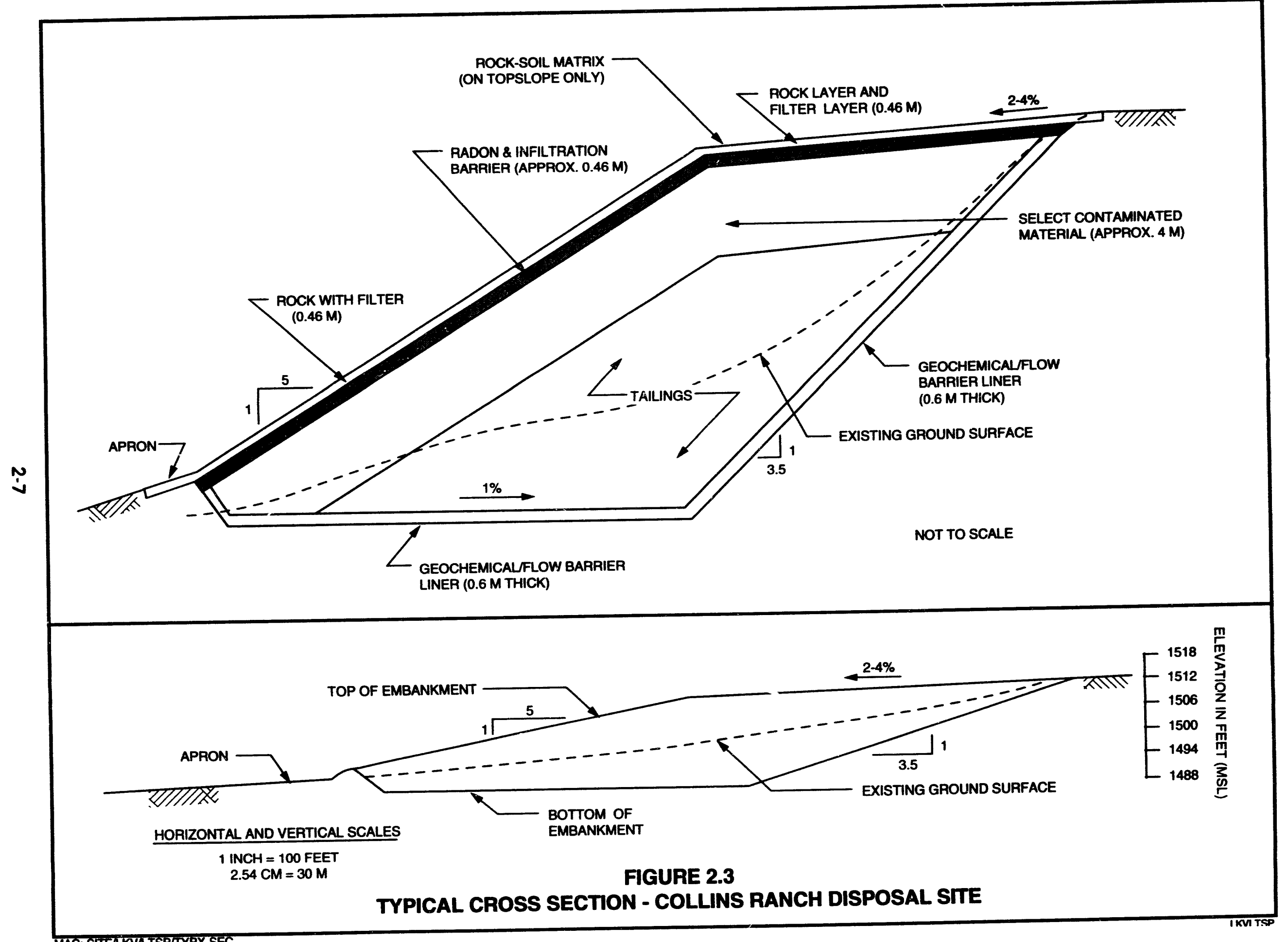




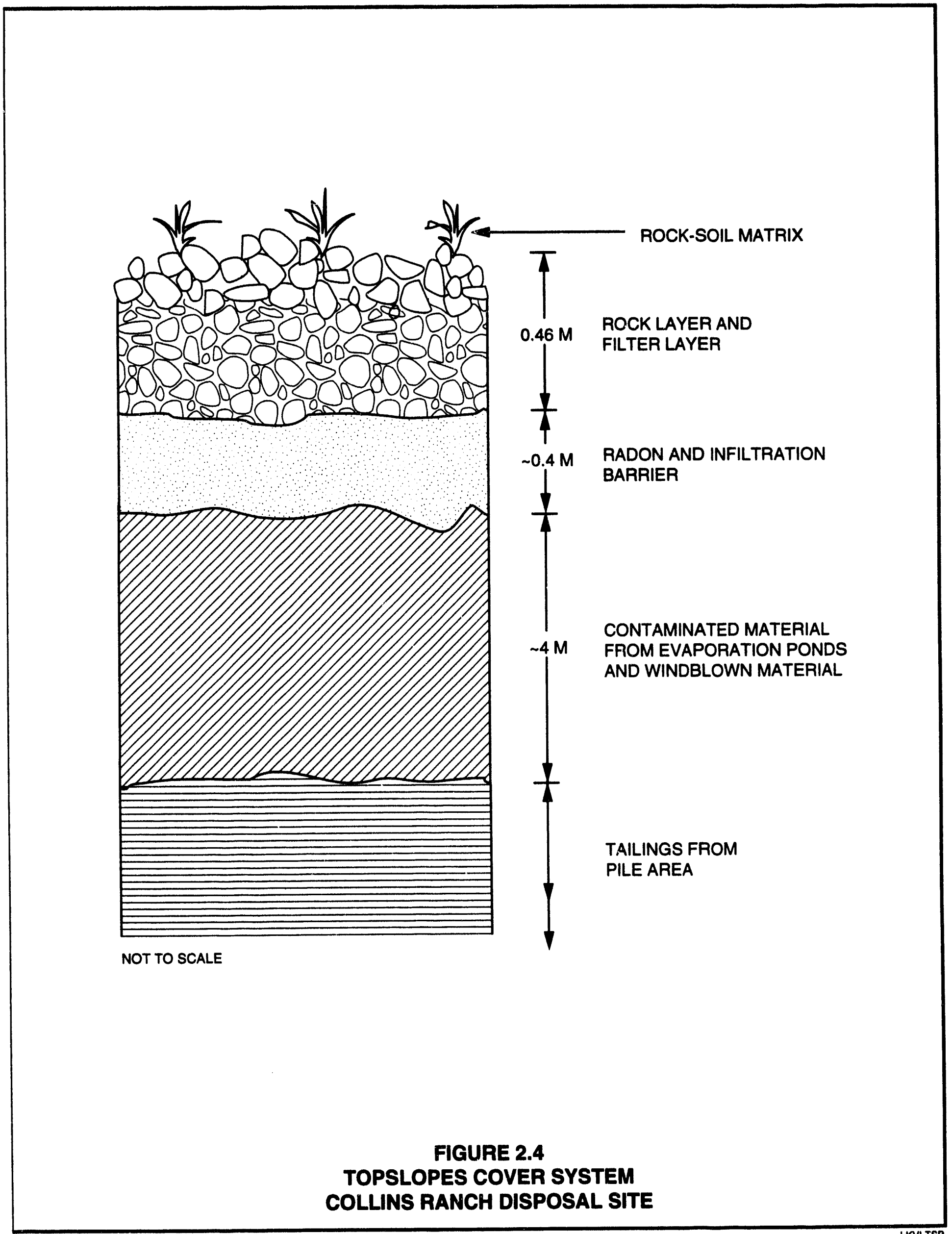


of the adjacent embankment cover. Significant precipitation events can create velocities capable of moving sediment buildup in the ditch. Flooding from the drainage area northwest of the site is not expected to reach the toe of the embankment.

Three major design features will mitigate potential ground water contamination at the Collins Ranch disposal site: 1) a geochemical/flow barrier liner on the sides and below the tailings, 2) a compacted radon/infiltration barrier above the tailings, and 3) a high-conductivity sand filter/drainage layer placed on top of the radon barrier.

The liner placed underneath the tailings and the radon barrier is composed of natural recompacted silt and clay soils. These types of soils have high neutralization, adsorption, and ion exchange potential and thus provide a high attenuative capacity to restrict downward contaminant migration through the liner.

The radon barrier is constructed of fine-grained soil that has a saturated hydraulic conductivity of less than $3 \times 10^{-9} \mathrm{ft} / \mathrm{s}\left(1 \times 10^{-7} \mathrm{~cm} / \mathrm{s}\right)$. The low permeability layer reduces surface water infiltration through contaminated material.

The high-conductivity sand filter/dreiriage layer is composed of clean sand and gravel with a hydraulic conductivity of 0.03 feet per second $(\mathrm{ft} / \mathrm{s})(1.0$ centimeters per second [cm/s]) or greater. The high hydraulic conductivity of this layer allows rapid water shed from the tailings pile.

The surface conditions of the disposal cell will be monitored during annual inspections to determine if the disposal cell and erosion protection measures are performing as designed. The following guidelines and criteria for corrective action or repairs should be used when inspecting the disposal cell:

- Crest/topslope - The disposal cell will be observed for evidence of uneven settling and cracking. Cracks in the clay infiltration/radon barrier, and any evidence of wind erosion and water erosion, such as gully formation, will be noted. If bare or thin spots or diseased or burned vegetation is found on the topslope cover, cover stability will be assessed. If established engineering methods determine the vegetated cover is unstable, corrective action to affected areas may be necessary. Temple's method for determining the stability of grass-lined channels (and siopes) would be used to assess the stability of a vegetated topslope area that was damaged or destroyed by disease or fire (Temple et al., 1987).

- Slopes-Modifications to the disposal site are most likely to occur on the lower portions of the slopes. Therefore, careful examination of the slope toe is a key part of this inspection. Settlement or sliding, although highly unlikely, will be apparent by the presence of bulges, depressions, cracks, or scarps. Any localized change in color (e.g., "stained" vegetation) or 
concentration of vegetation will be described and examined for evidence of seepage. The slopes will ve examined for evidence of animal intrusion, burrowing, changes in vegetation, and human activity. During the prelicensing phase, the TAC biologist monitors these conditions. In addition, the GJPO conducts an annual prelicensing inspection (Burt and Cox, 1993).

- Drainape ditch and drainage channels - The inspectors will walk along the entire length of each channel to determine whether the channels are functioning and can be expected to continue to function as designed. The channels and sideslopes will be examined for evidence of erosion or sedimentation, slides, incipient erosion channels, debris, or growing vegetation. The sideslopes will also be examined for evidence of piping or burrowing by animals, which could lead to material sloughing into the channel.

- Periphery (within site boundaries) - The boundaries will be examined for gully or rill formation, mounding caused by sediment transport by wind and water, and vegetation changes. The area will also be examined for evidence of water seepage, such as wet spots, and surface ponding.

The ground water protection design strategy will minimize the migration of contaminants from the disposal cell. Seepage from the disposal cell will be minimal because of the vegetated topslope cover and the low permeability radon barrier, and because the contaminated materials were placed at their optimum moisture content. Vegetation on the topslope evapotranspirates surface water and water held in storage in the rock/soil matrix layer. Thus, the total volume of water from precipitation and snowfall that could potentially infiltrate the topslope cover is greatly reduced. The average saturated hydraulic conductivity of compacted samples of the silty-clay radon barrier material is less than $3 \times 10^{-9} \mathrm{ft} / \mathrm{s}\left(1 \times 10^{-7} \mathrm{~cm} / \mathrm{s}\right)$; therefore, water movement through the radon barrier is extremely slow. After pressure equilibration within the disposal cell (generally a few months), all contaminated materials will be near their optimum moisture content, further protecting the ground water near the disposal site. This protection is two-fold. First, the hydraulic conductivity of materials placed at optimum moisture content is very low (typically 80 to 85 percent saturated). The unsaturated hydraulic conductivity at optimum moisture content is often 2 orders of magnitude less than the value of saturated hydraulic conductivity. Second, the volume of moisture stored in the contaminated material that can potentially seep from the material matrix is greatly reduced.

The compliance strategy includes the attenuating properties of the $2-\mathrm{ft}$ $(0.61-\mathrm{m})$-thick geochemical barrier and the more than $40 \mathrm{ft}(12 \mathrm{~m})$ (to the water table) of fine-grained sediments beneath the tailings. The movement of any contaminants that may leach from the disposal cell will be retarded by the materials in the geochemical barrier and in the unsaturated zone. 


\subsection{SITE DRAWINGS AND PHOTOGRAPHS}

At the completion of remedial action, disposal site as-built conditions were documented with as-built drawings and photographs (MKF, 1991). This information illustrates baseline conditions for comparison to future disposal site conditions.

A site atlas was prepared that includes vicinity maps, a topographic map, and a disposal site map. This atles will become part of the Lakeview permanent site file. The site atlas will be updated, as necessary, after each site inspection. All drawings, maps, and photographs will be archived by the UMTRA Project Document Control Center (UPDCC). These maps, drawings, and photographs may be further modified by G.IFO, as necessary, and GJPO will be responsible for maintaining and archiving these maps, drawings, and photographs after the Lakeview permanent site file is transferred to the GJPO. An index of the Lakeview permanent site file is provided in Attachment 3.

\subsection{DISPOSAL SITE VICINITY MAP}

The Collins Ranch disposal site vicinity map (Plate 1 ) encompasses an area with a radius of approximately $1.5 \mathrm{mi}(2.4 \mathrm{~km})$ from the center of the disposal site. A larger radius was not necessary because the disposal site is located in a remote area with uniform land use; the nearest town is located $7 \mathrm{mi}(11 \mathrm{~km})$ to the south.

The vicinity map documents the disposal site boundary, the disposal cell, land ownership around the disposal site (private and U.S. Forest Service land), longitude and latitude, section, township, range, principal meridian, primary drainage systems, and roads.

The map can be found in the site atlas, which will be maintained in the Lakeview permanent site file at GJPO after site licensing.

The vicinity map will be updated, as necessary, after each scheduled site inspection. If changes to the map are required, a new map will be prepared which will include the revision number and the year of revision.

\subsection{DISPOSAL SITE TOPOGRAPHIC MAP}

The Collins Ranch disposal site topographic map (Plate 2), prepared immediately after the completion of remedial action, was compiled from a final topographic survey of the disposal site area. The final topographic survey was conducted in accordance with the standards of the Manual of Photogrammetry (ASP, 1980). The following specifications were used in developing the map: a scale of 1 in = $200 \mathrm{ft}(1 \mathrm{~mm} \equiv 250 \mathrm{~m})$, a contour interval of $2 \mathrm{ft}(0.6 \mathrm{~m})$, and coverage of the disposal site and an area of $0.25 \mathrm{mi}(0.4 \mathrm{~km})$ around the site perimeter. 
In addition to topography, the map defines the following:

- Disposal site property boundaries, fences, gates, and access roads.

- Outline of the toe base and crest of the disposal cell.

- Location and extent of rock cover.

- Ground water monitor wells and access roads.

- Survey control stations.

- Permanent site surveillance features (e.g., monuments, markers, and signs).

- Other surveillance features (e.g., settlement plates).

- Site coordinate system.

When the Collins Ranch disposal site topographic map is updated, the revised map will include the year of revision and the revision number.

The Collins Ranch disposal site topographic map will serve as the base map for site inspections (Section 6.7). A new, separate inspection map will be prepared after each inspection. Each site inspection map will indicate the year of the inspection and the type of inspection.

All Collins Ranch disposal site base maps and periodic disposal site inspection maps will become part of the Lakeview permanent site file (Attachment 3).

\subsection{DISPOSAL SITE AS-BUILT DRAWINGS}

A set of as-built drawings provided by Morrison Knudsen-Ferguson, the Remedial Action Contractor (RAC), illustrates final disposal cell construction and final disposal site conditions. These drawings were used to prepare the Collins Ranch disposal site topographic map. They may be used to document changes in physical site conditions or the disposal cell over time and to develop corrective action plans, if required.

At licensing, the RAC will transfer one original set of as-built drawings to the GJPO. These drawings will be filed in the site atlas, which will be maintained in the Lakeview permanent site file (Attachment 3) at the GJPO.

\subsection{SITE BASELINE PHOTOGRAPHS}

A photographic record of the final site conditions at the Collins Ranch disposal site will be included and maintained in the Lakeview permanent site file (Attachment 3). This record consists of a series of aerial and ground photographs that provide a baseline visual record of final site construction activities and final site conditions to complement the as-built drawings. In addition, the final completion report for the disposal site contains a complete set of photographs that documents each phase of construction (MKF, 1991). The postconstruction photographs provide an orientation tool prior to site inspections and a baseline record of surveillance features. 
Two sets of aerial photographs were taken of the Collins Ranch disposal site after surface remedial action was completed. The first set was taken in October 1989, immediately after remedial action was completed, to support immediate preparation of the disposal site topographic map. The second set was taken in June 1990, at the end of the first growing season, to document the established cover vegetation. This second set of photographs provides a permanent record of site conditions, enabling inspectors to monitor changes in site conditions (e.g., erosion patterns, vegetation changes, land use) over time. The photographs are a useful orientation tool before disposal site inspections. The need for new aerial photographs will be evaluated at 5-year intervals, beginning the year the site license becomes effective. Table 3.1 summarizes the specifications for aerial photographs at the Collins Ranch disposal site. More detailed guidance is provided in Attachment 3 of the Guidance for Implementing the UMTRA Project Long-term Surveillance Program (DOE, 1992a).

\subsection{SITE INSPECTION PHOTOGRAPHS}

Photographs will be taken during disposal site inspections to document conditions at the disposal cell and the disposal site. These photographs will provide a continuous record for monitoring changing conditions over time. The photographs can be compared with the baseline photographs to monitor site integrity.

Each photograph will be recorded individually on a site inspection photo log (Attachment 4). An appropriate description of the feature photographed, including azimuth (if necessary), will be entered into the log. Copies of the disposal site inspection photographs and the photo log will be included in annual disposal site inspection reports.

If possible, a photograph will include a reference point such as a survey monument, boundary monument, site marker, or monitor well. For large-scale features such as drainage ditches or disposal cell slopes, a nortti arrow and a scale will be included for reference.

For specific areas where a photograph is used to monitor change over time, the distance from the feature and the azimuth should be recorded, and all subsequent photographs should be taken from the same orientation to provide an accurate picture of changing conditions. The magnetic declination of the compass should be corrected for true north. This information will also be provided on the inspection checklist and photo log.

All site inspection photographs taken, as well as all corresponding photo log forms, shall be maintained in the permanent Lakeview site file. 
Table 3.1 Aerial photography specifications for the Collins Ranch disposal site

Area to be photographed

Products to be delivered

Flight date

\section{Camera}

Film

Filter

Flight line coverage

Ground control
Final disposal site plus a minimum of $0.25 \mathrm{mi}(0.4 \mathrm{~km})$ beyond site boundaries unless site conditions require otherwise.

One set of vertical color, infrared stereo contact prints, 9-in $(230 \mathrm{~mm})$, scale 1 in $=200 \mathrm{ft}(1 \mathrm{~mm}=240 \mathrm{~m})$ (representation fraction 1:2400); double weight, glossy, not trimmed.

One index map, scale 1 in $=200 \mathrm{ft}(1 \mathrm{~mm}=240 \mathrm{~m})$; flight lines and frame numbers will be provided.

One set of 2 each of low and high oblique photographs (and negatives) in natural color, $8-\times 10$-in (200-x 250-mm); or 9- $\times$ 9-in (23- $\times 23-\mathrm{mm})$ contact prints.

To be determined upon acceptance of this LTSP.

Precision, 9- $\times$ 9-in $(230-\times 230-\mathrm{mm})$ format for vertical photos. A 35-millimeter (single lens reflex) or larger format camera for oblique photos is acceptable.

Eastman-Kodak Aerochrome Infrared 2443, or its equivalent, for vertical photos.

Eastman-Kodak Ektacolor, or its equivalent, for oblique photos.

Wratten Nos. 12 or 15 for infrared photos. Skylight filter for color photos.

60 percent end overlap; 30 percent average side overlap.

Control stations will be second order, Class 1, for horizontal control and third order for vertical control (standard U.S. Geological Survey map accuracy specifications). 


\section{Eatures to be photographed}

The following site features should be documented with photographs during every scheduled inspection at the Collins Ranch disposal site:

- Permanent site surveillance features (Plate 2).

- Fences, gates, access roads, perimeter roads, and paths.

- Drainage channel.

- Trench drains (5).

- The disposal cell (top, sides, apron, and surrounding area). Panoramic sequences of photographs from selected vantage points may be used for this purpose.

- Any evidence of erosion (e.g., gullies, rills) that the inspector considers significant and includes in the text of the inspection report.

- Any off-site features that the inspector considers significant and includes in the text that may affect the site in the future.

- Vegetation (site area and cover).

- Disposal cell embankment and sideslope.

- Erosion protection material (riprap).

- U.S. Coast and Geodetic Survey (USCGS) triangulation station monument located at the summit of Augur Hill.

- Triangulation station reference markers (2).

Any new or potential problem areas identified during a site inspection will be well documented with photographs. Photographs will also be taken to record developing trends and to allow inspectors to make reasonable decisions concerning additional inspections, custodial maintenance or repairs, or corrective action. 


\subsection{PERMANENT SITE-SURVEILLANCE FEATURES}

Survey and boundary monuments, site markers, and perimeter signs are the permanent surveillance features of the Collins Ranch disposal site. Three boundary monuments and two of the three survey monuments define the five corners of the fenced. irregularly shaped permanent disposal site. Twelve perimeter (warning) signs are placed at intervals around the disposal site so that one or more of the signs is visible in daylight to a person approaching from any direction. One of the perimeter signs, which serves as an entrance sign, and one site marker are placed near the southeast corner at the authorized entrance to the disposal site. The other site marker is placed near the center of the crest of the disposal cell.

The construction and emplacement of the site surveillance features, described below, meet the specifications delineated in DOE's Guidance for Implementing the UMTRA Project Long-term Surveillance Program (DOE, 1992a).

\subsection{SURVEY MONUMENTS}

The three permanent survey monuments (Figure 4.1), Berntsen RT-1 markers, are set into the top of a reinforced and poured-in-place concrete cylinder with the dimensions shown in Figure 4.1. The bottom of the concrete cylinder is a minimum of $3 \mathrm{ft}(0.9 \mathrm{~m})$ below land surface $(\mathrm{b} / \mathrm{s})$. A depth of $3 \mathrm{ft}(0.9 \mathrm{~m})$ is sufficient to prevent displacement of the survey monuments from frost heave. The four steel reinforcing bars (Figure 4.1) permit discovery by a metal detector if the monument becomes buried over time. The three survey monuments establish permanent horizontal control based on the project grid system and are referenced to the USCGS triangulation station located at the summit of Augur Hill.

\subsection{BOUNDARY MONUMENTS}

Three Berntsen federal aluminum survey monuments, Model A-1, were used for three of the five boundary monuments (Figure 4.2). Two corners of the disposal site are designated by Berntsen RT-1 markers. The ceramic magnets epoxied in the cap and base of the A-1 monuments are vertically oriented for easier detection if they become buried. The boundary monuments are set with the base 38 in $(970 \mathrm{~mm})$ bls and 10 in $(250 \mathrm{~mm})$ above the ground surface (Figure 4.2).

\subsection{SITE MARKERS}

Two unpolished granite markers with the dimensions shown in Figures 4.3 and 4.4 identify the Collins Ranch disposal site, the general location of the stabilized disposal cell within the site boundaries, the date of closure (June 29, 1988), the dry tonnage of tailings 9736,000 tons [667,700 tonnes]) and the curies of radioactivity (42 curies [15 $\times 10^{12}$ becquerels]) of radium-226 (Ra-226) (Figure 4.5). 


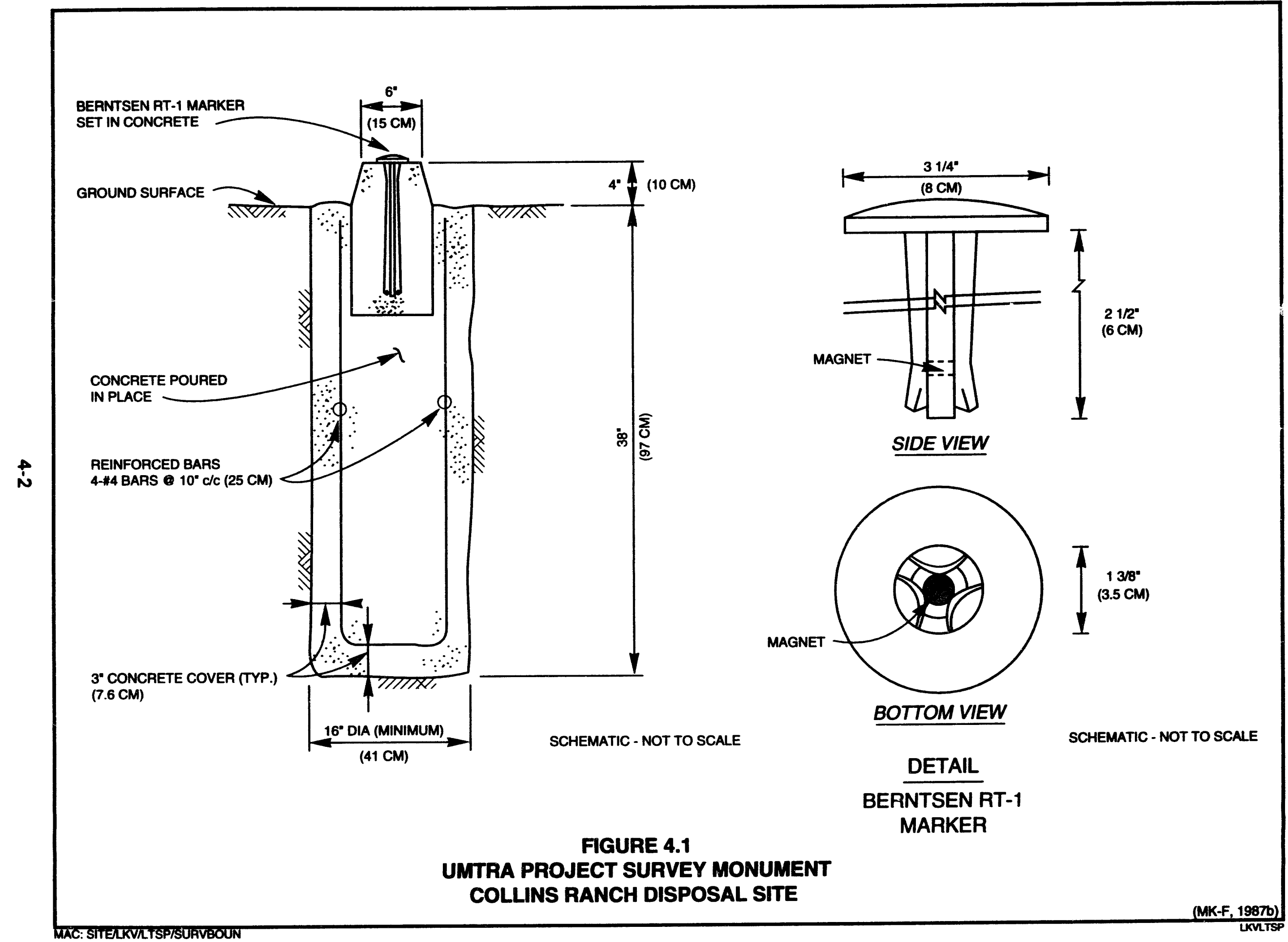




\section{BERNTSEN FEDERAL ALUMINUM BOUNDARY MONUMENT, MODEL A-1, STANDARD LOGO CAP}

$\vec{\omega}$
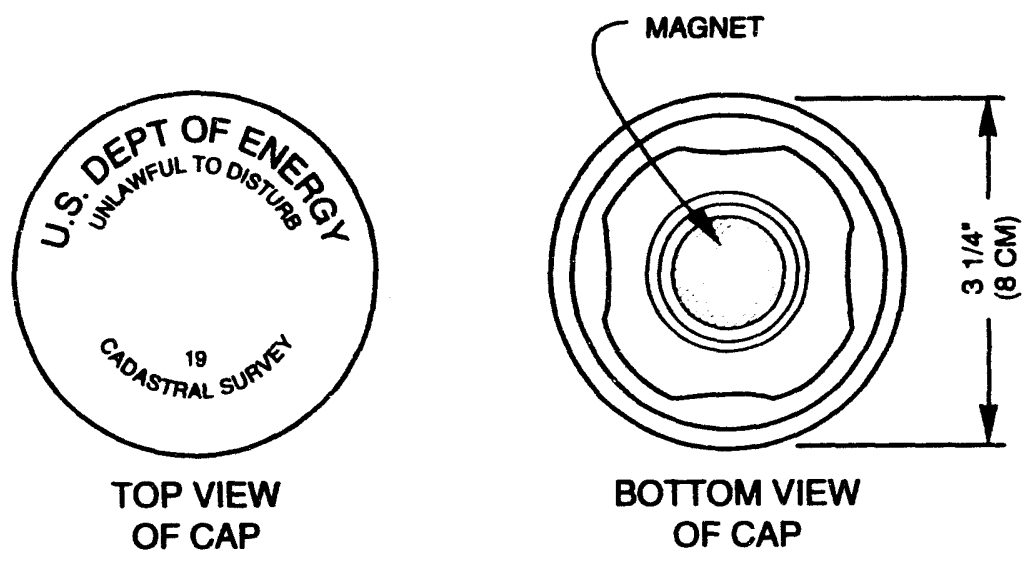

BOTTOM VIEW

OF CAP

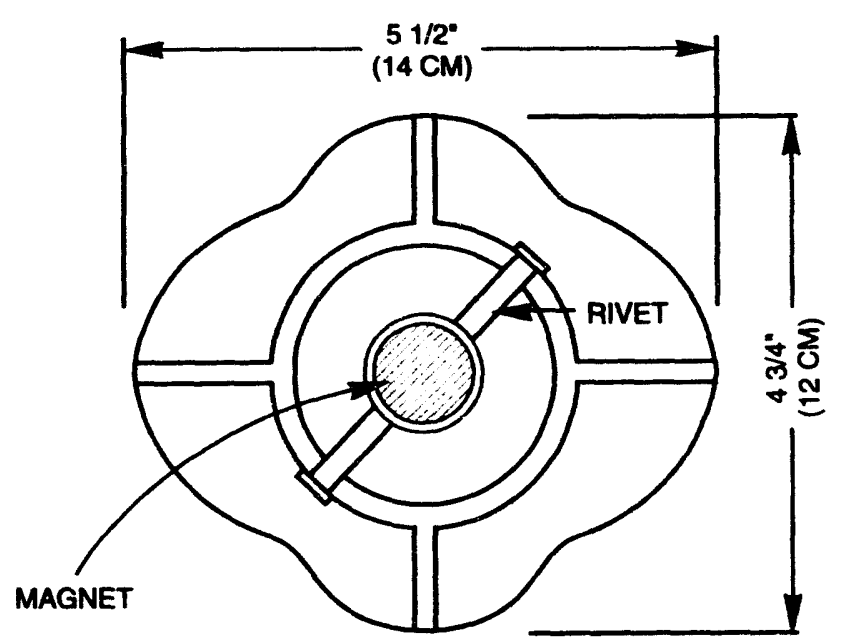

TOP VIEW OF BASE

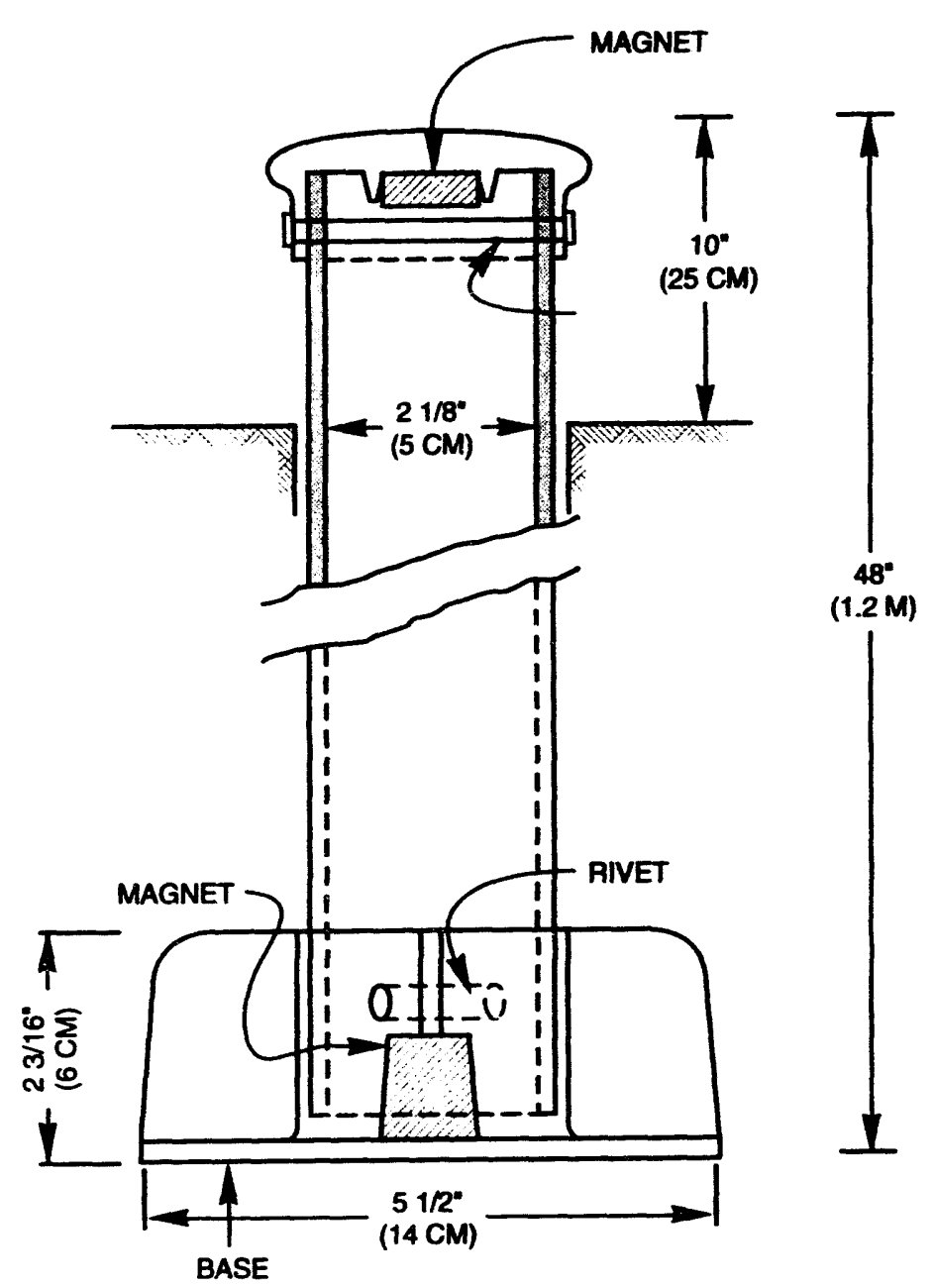

SCHEMATIC - NOT TO SCALE

FIGURE 4.2

UMTRA PROJECT BOUNDARY MONUMENT-

COLLINS RANCH DISPOSAL SITE 


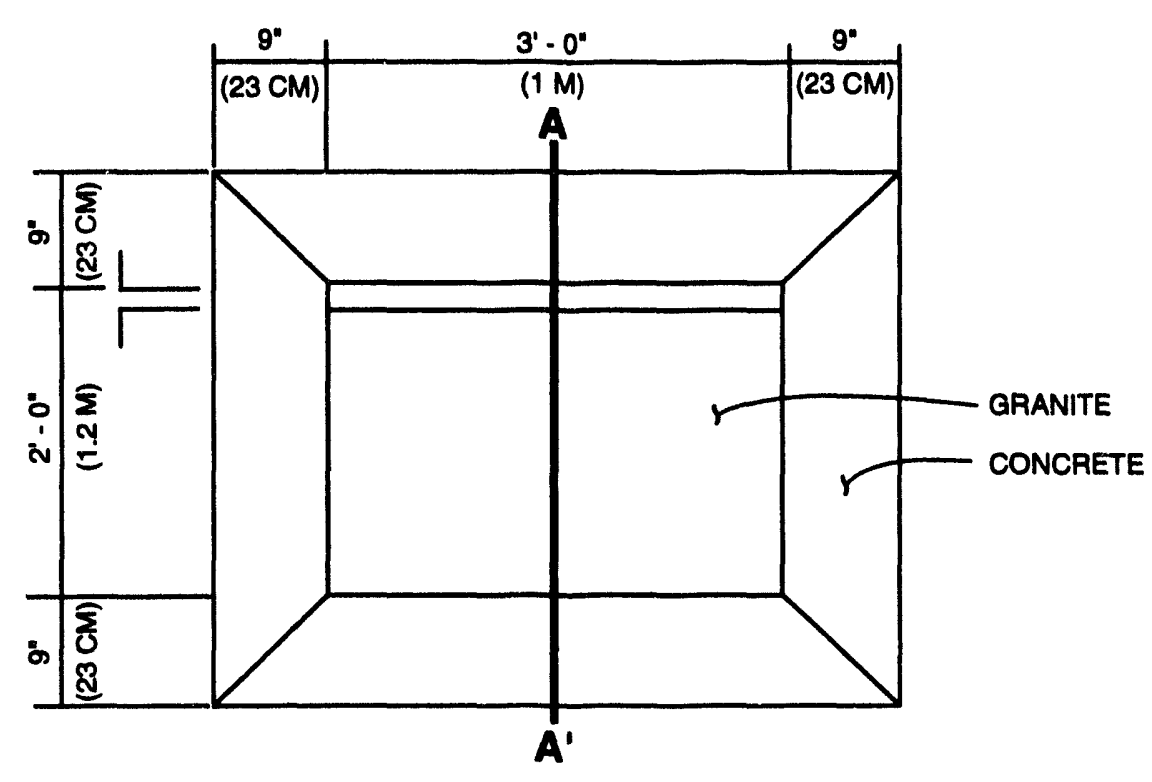

PLAN VIEW

SCHEMATIC - NOT SHOWN TO SCALE

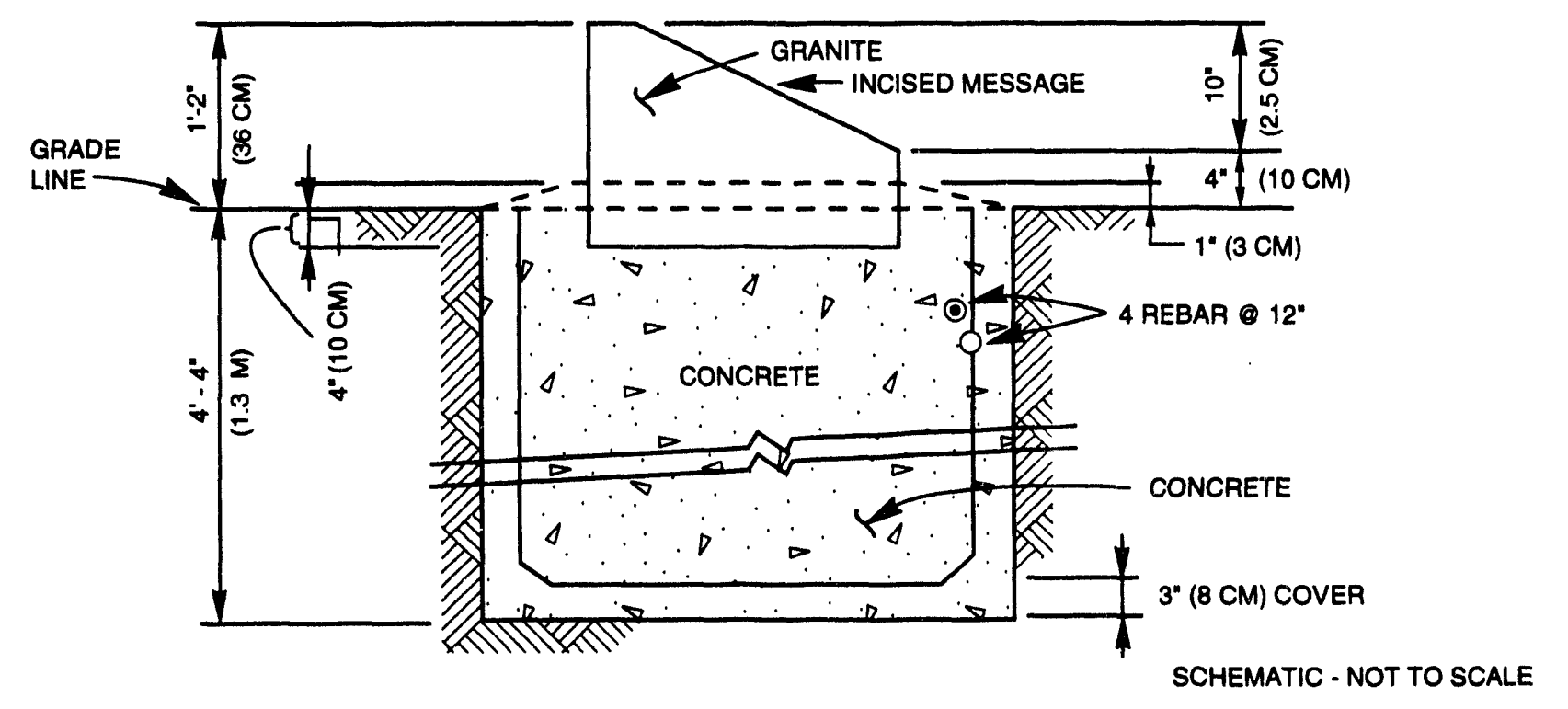

SECTION A-A'

FIGURE 4.3

UMTRA PROJECT ENTRANCE SITE MARKER COLLINS RANCH DISPOSAL SITE 


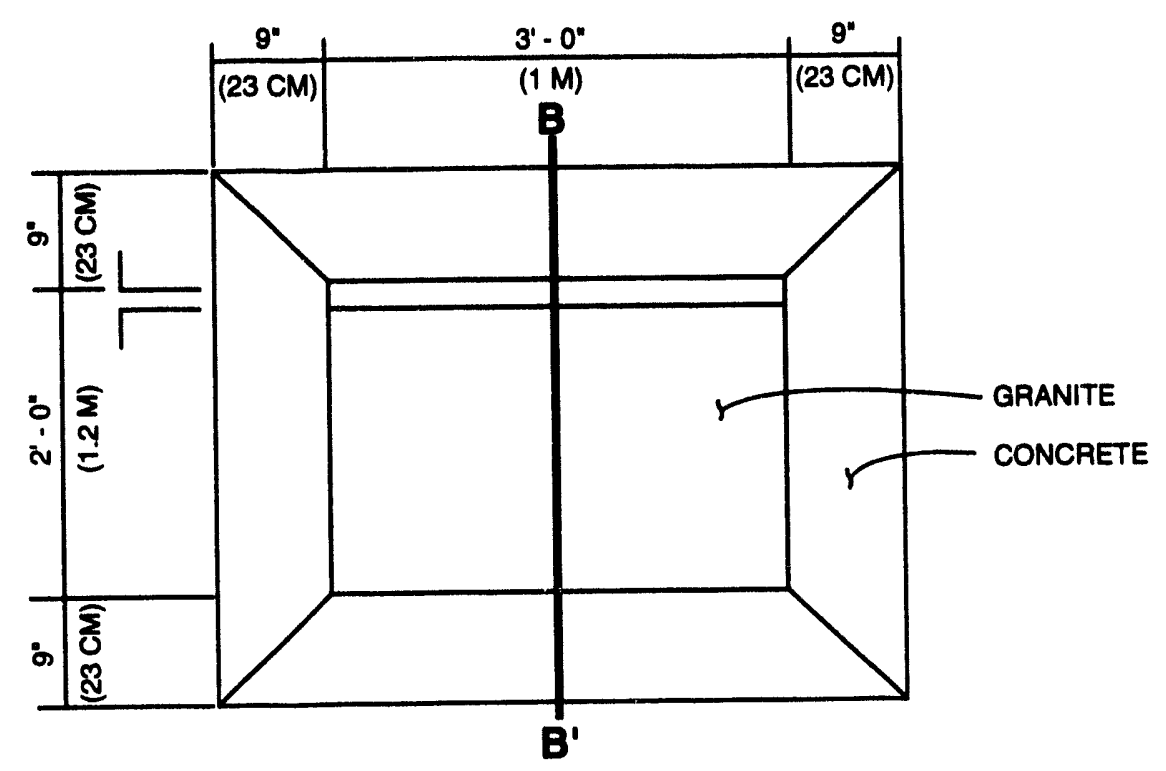

PLAN VIEW

SCHEMATIC - NOT TO SCALE

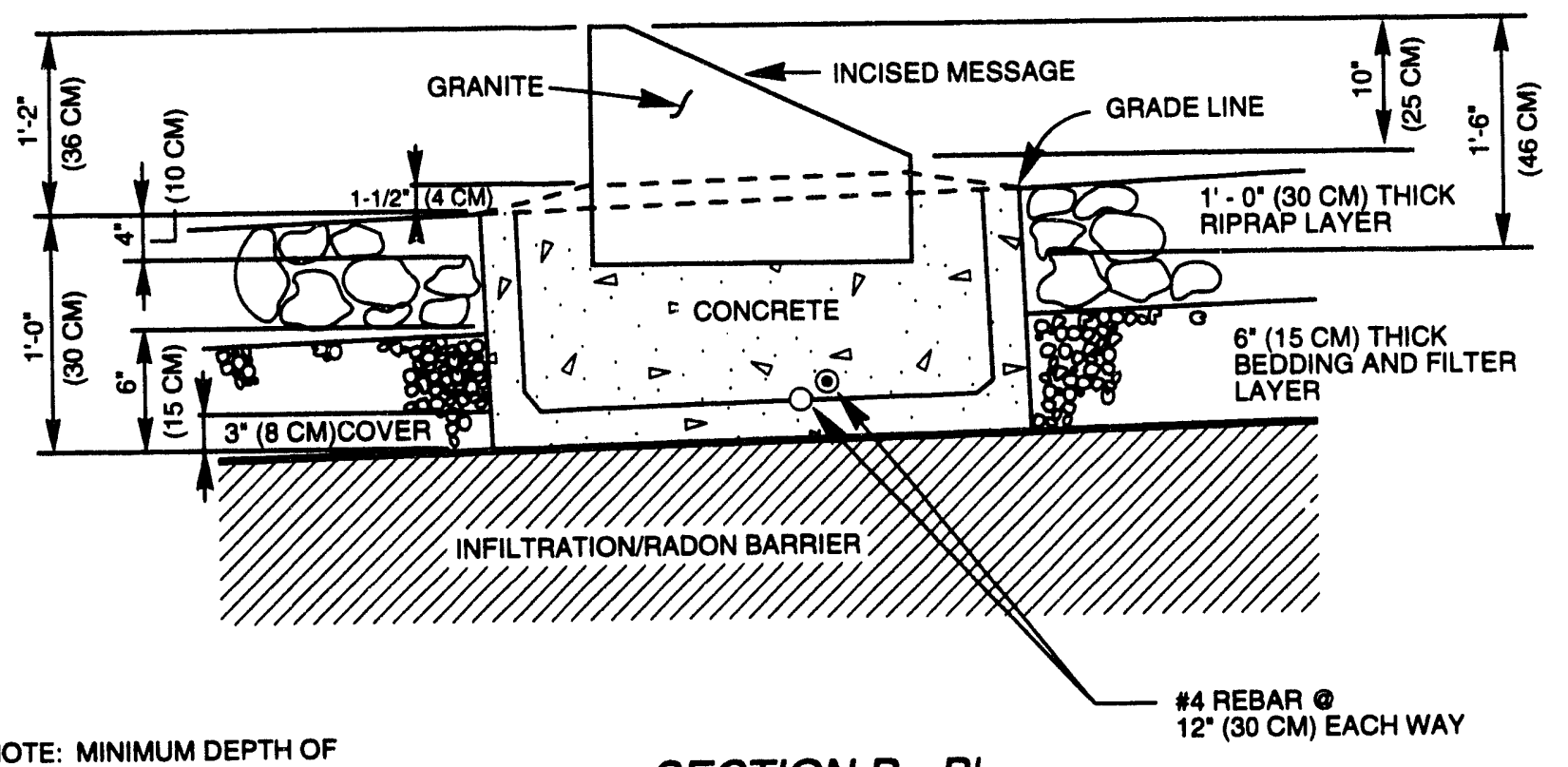

INCISING TO BE $1 / 4^{\prime \prime}(0.6 \mathrm{CM})$

SECTION B - B'

SCHEMATIC - NOT TO SCALE

FIGURE 4.4

UMTRA PROJECT SITE MARKER AT CREST OF DISPOSAL CELL COLLINS RANCH DISPOSAL SITE 


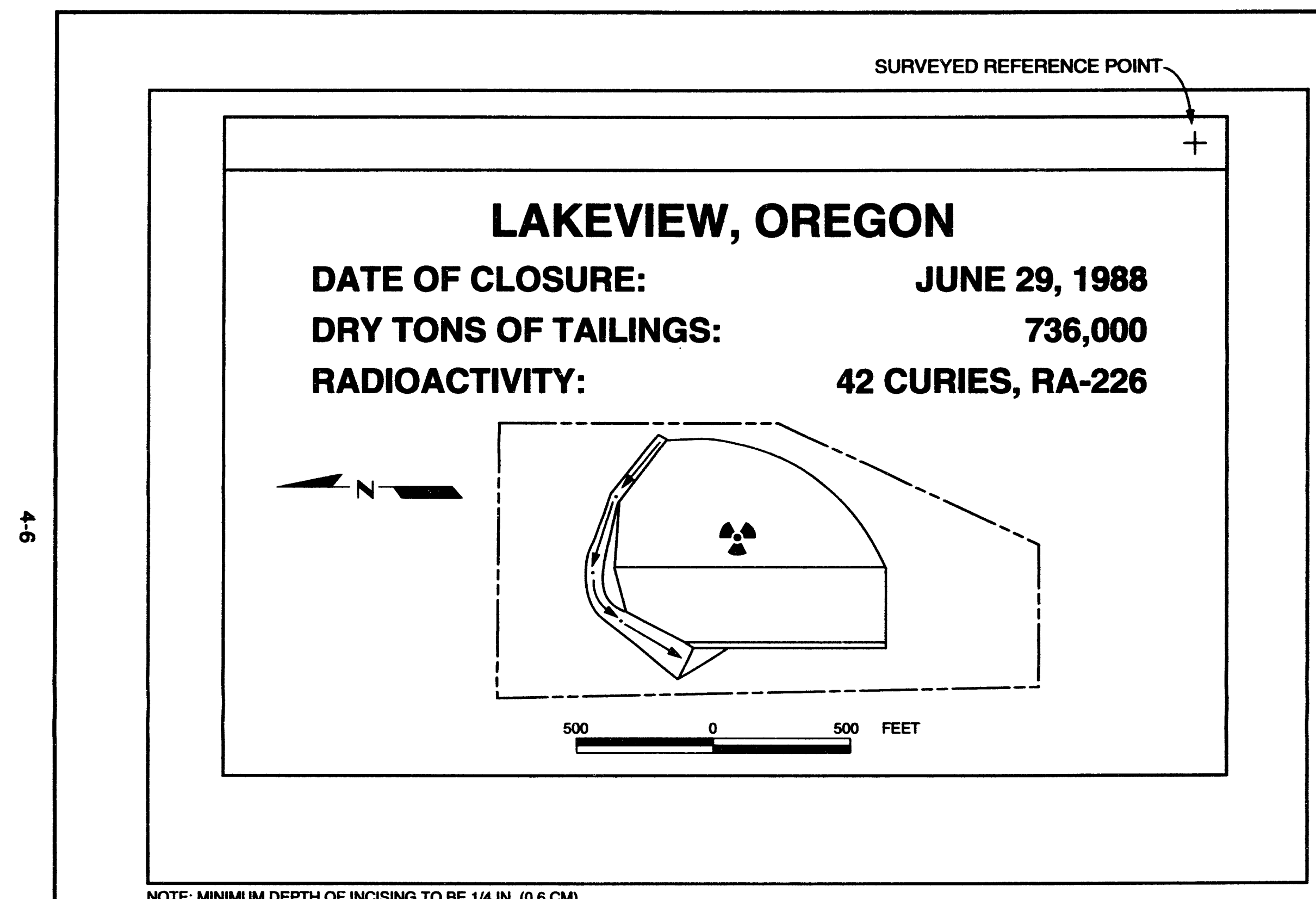

FIGURE 4.5

UMTRA PROJECT SITE MARKER INCISED MESSAGE COLLINS RANCH DISPOSAL SITE 
Site marker SMK-1 near the entrance to the site is set in a bed of reinforced concrete that extends $3 \mathrm{ft}(0.9 \mathrm{~m})$ bls (Figure 4.3). Site marker SMK-2 at the crest of the disposal cell is set in a bed of reinforced concrete that extends to the top of the radon barrier (Figure 4.4). The excavation and setting of SMK-2 was conducted with minimum disturbance of the surrounding erosion protection layers.

\subsection{ENTRANCE AND PERIMETER SIGNS}

A warning sign with the following information is placed at the entrance to the disposal site: the name of the disposal site, the international symbol indicating the presence of radioactive material, a notice that trespassing is forbidden on this federally owned site, and the telephone numbers of the Oregon Department of Energy. In addition to the entrance sign, 11 signs mounted on steel posts are placed at approximately equal intervals around the site perimeter. The perimeter signs display the international symbol indicating the presence of radioactive material and state that the disposal site is U.S. Government property, that it contains uranium mill tailings, and that trespassing is forbidden.

The signs are constructed in accordance with the dimensions and specifications shown in Figures 4.6 and 4.7, mounted with the tops of the entrance and perimeter signs 70 in $(1780 \mathrm{~mm})$ above the ground surface. The sign posts are embedded in concrete to a depth of 38 in $(970 \mathrm{~mm})$ bls.

\subsection{SETTLEMENT PLATES}

The total long-term settlement of the disposal cell can be measured using the four settlement plates installed after the cell was completed. Three of the plates are placed in the topslope cover and the remaining plate is set into the sideslope cover. All the plates are installed to the specifications shown in Figure 4.8. Excavation of cover material was kept to a minimum during placement of the settlement plates, and any cover materials disturbed during placement were replaced following original design specifications.

Initial elevations of the settlement plates were determined in late 1989. A subsequent survey of plate elevations in December 1990 determined that settling or swelling of the disposal cell ranged from 0.1 to 0.3 in (3.0 to $8.0 \mathrm{~mm}$ ). As the detected change in the elevations of the plates over a period of 1 year was insignificant, no further monitoring of settlement at the Collins Ranch disposal cell is scheduled at this time. 


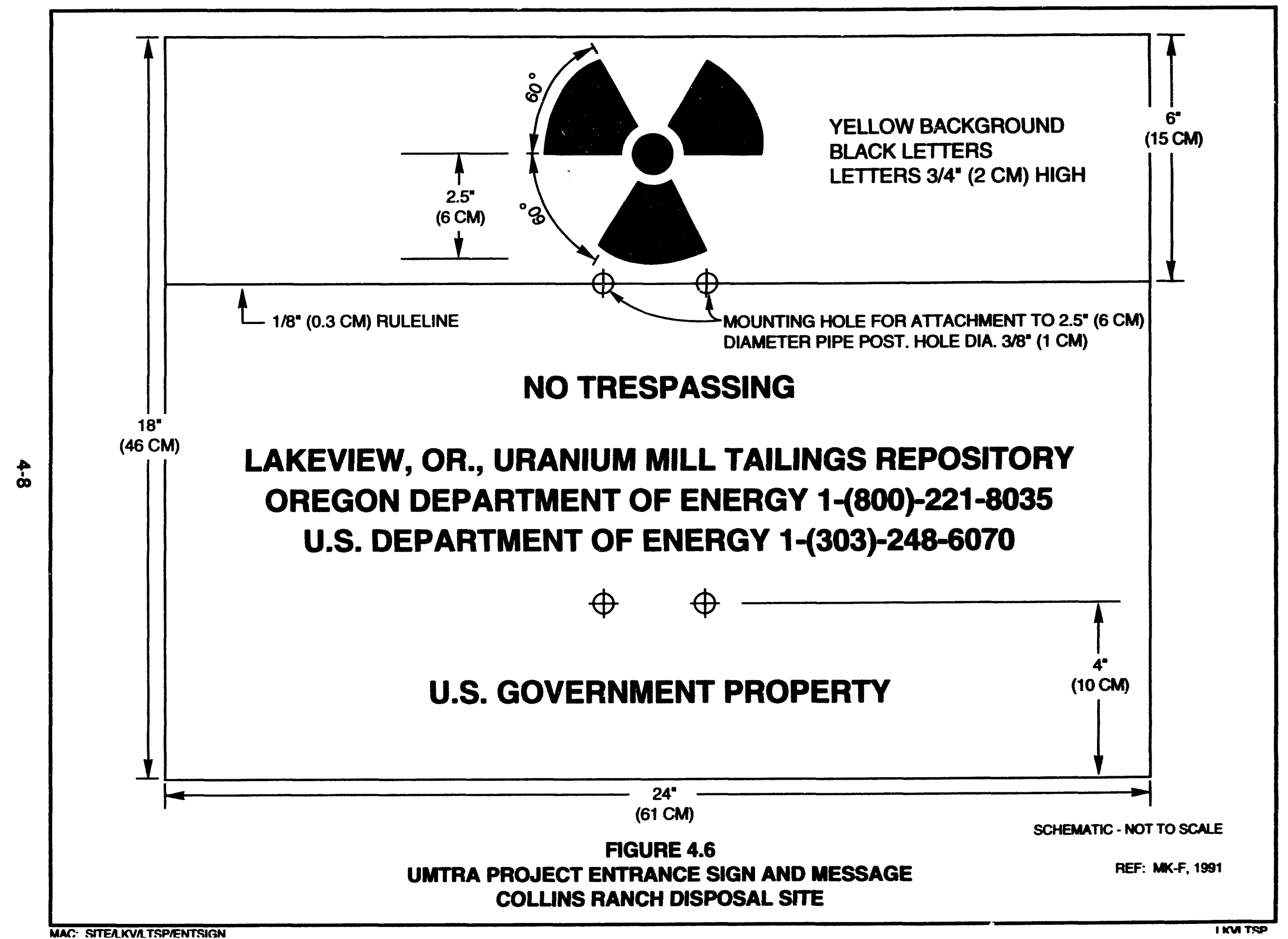




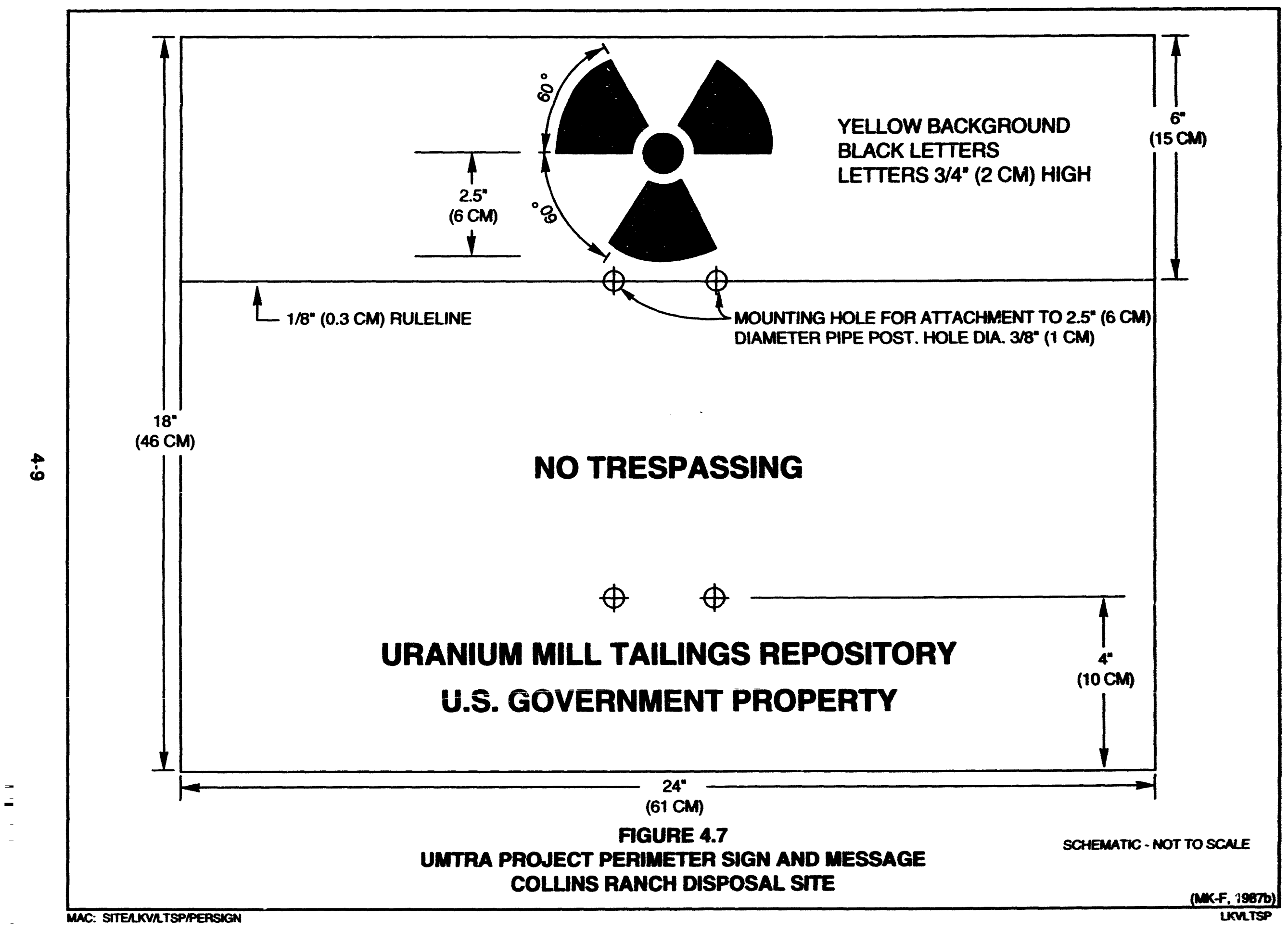




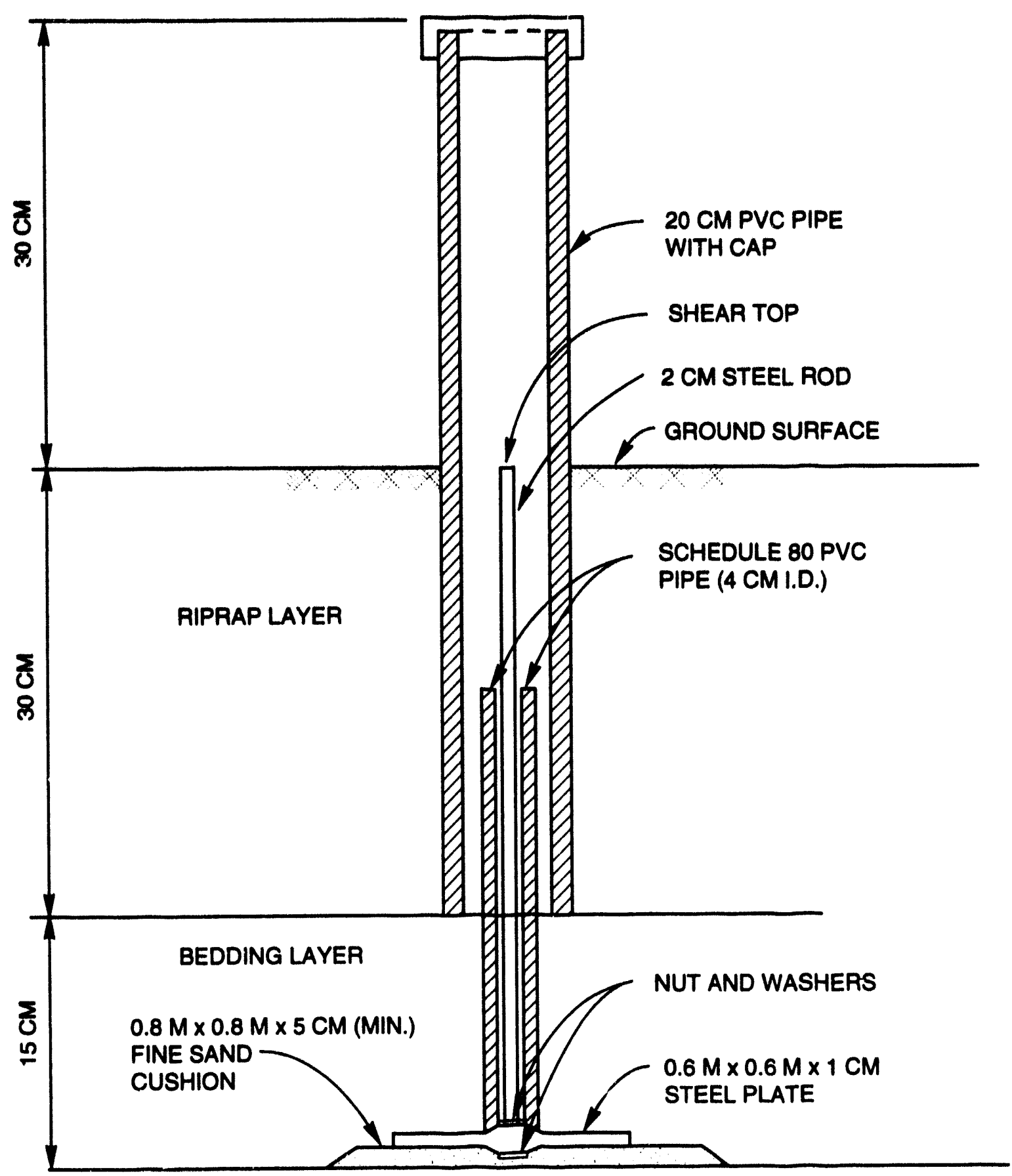

RADON BARRIER LAYER

SCHEMATIC - NOT TO SCALE

FIGURE 4.8

UMTRA PROJECT SETTLEMENT PLATES COLLINS RANCH DISPOSAL SITE 


\subsection{OROUND WATER MONITORING}

NRC regulations in 10 CFR 40.27 (b) require that the disposal site LTSP describe existing ground water conditions and that all ground water activities or strategies at the disposal site comply with the proposed EPA ground water standards (52 FR 36000) published in 1987. The DOE will comply with the published proposed standards until the final standards are in effect. When the proposed standards become final, the DOE will reevaluate the monitoring program for compliance with the final standard.

The criteria for establishing a ground water monitoring program (52 FR 36000) require a ground water monitoring program for the UMTRA Collins Ranch disposal site. The ground water monitoring program will be implemented and conducted over a specific time period adequate to demonstrate that the initial performance of the disposal cell meets the design requirements. The DOE must also demonstrate that any cleanup or control of existing processing-related ground water contamination at the Lakeview processing site complies with the proposed EPA ground water protection standards in 52 FR 36000 . Ground water compliance program activities for the processing site will be conducted and documented separately from this LTSP.

Long-term ground water monitoring at the disposal site involves the performance assessment developed in conjunction with the disposal cell design. It also includes identifying specific hazardous constituents that will be monitored, as necessary, establishing concentration limits for those constituents (DOE, 1992a). Initial site characterization data and monitoring recommendations were incorporated in the Lakeview RAP (DOE, 1992b), EA (DOE, 1985a), and disposal site characterization report (DSCR) (DOE, 1985b). Some of these initial monitoring recommendations have been modified, based on a review of historical information and new data acquired since preparation of the Lakeview RAP. These modifications are discussed below.

\subsection{GROUND WATER CHARACTERIZATION}

The DOE's characterization of the hydrogeologic units, aquifer hydraulic and transport properties, tailings materials, and geochemical conditions at the Collins Ranch disposal site (presented in detail in the Lakeview RAP [DOE, 1992b]) is summarized below.

The DOE demonstrated in the RAP that this disposal site will comply with Subpart $A$ of 40 CFR 192 as issued in 52 FR 36000 by meeting maximum concentration limits $(\mathrm{MCL})$ for designated hazardous constituents in the uppermost lacustrine aquifer at the point of compliance (POC) (Figure 5.1) (DOE, 1992b). Compliance with the ground water standards will be achieved for the following reasons:

- Very little seepage (saturated hydraulic conductivity flux of less than $3 \times 10^{-9} \mathrm{ft} / \mathrm{s}\left[1 \times 10^{-7} \mathrm{~cm} / \mathrm{s}\right]$ ) will be transmitted through the disposal cell foundation (DOE, 1992b). Precipitation infiltration and diffusion of hazardous constituents in the tailings are retarded by a low-conductivity cap covering the cell. 


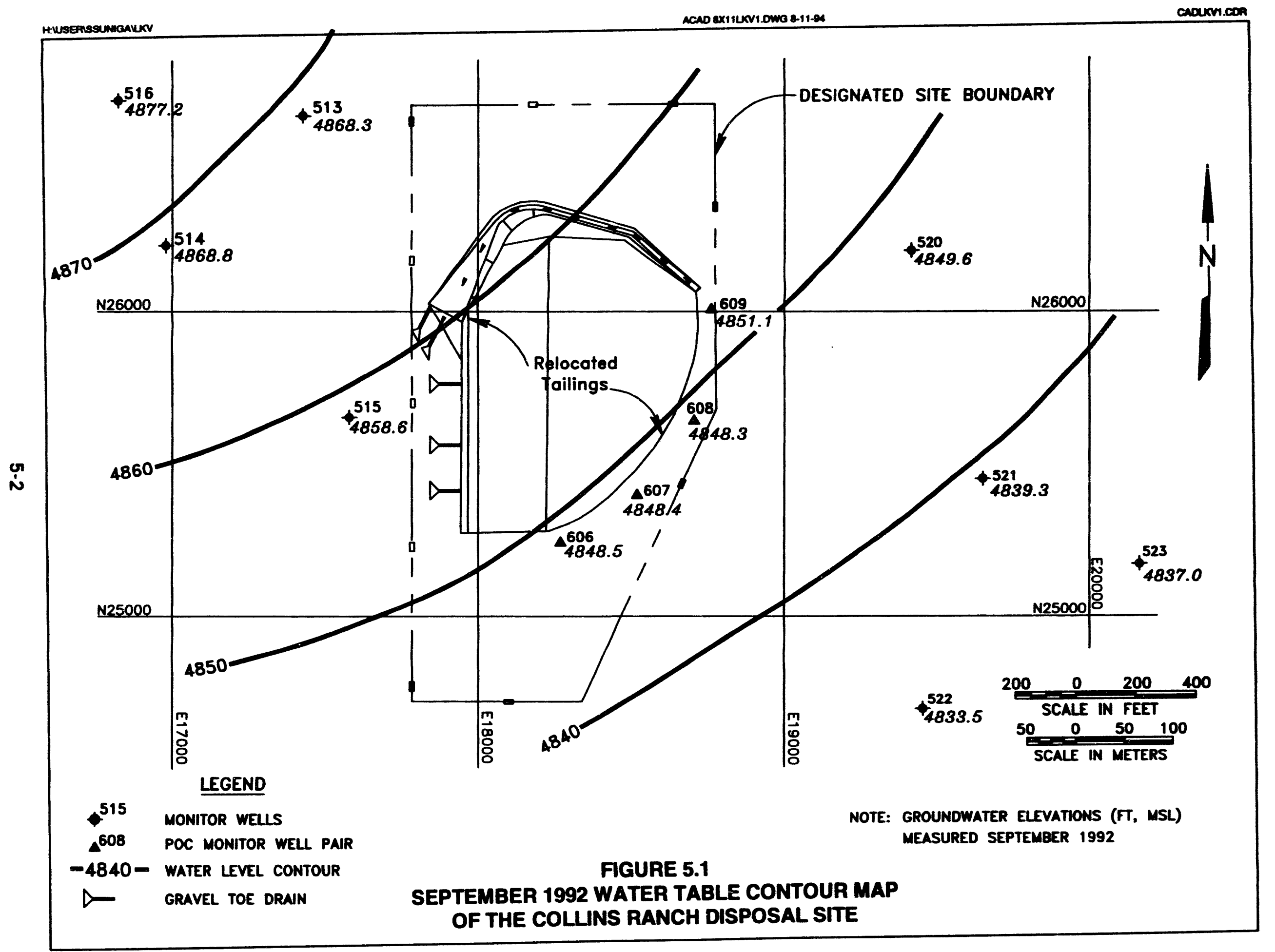


- Geochemical characteristics of the foundation materials are favorable for attenuating hazardous constituents in tailings seepage from the base of the disposal cell. More than $40 \mathrm{ft}(12 \mathrm{~m})$ of unsaturated sediments consisting of predominantly silts, silty sands, and clayey sand-silt mixtures are beneath the geochemical/flow barrier. Such sediments provide high dispersivity and the very large-particle surface area that sorption processes require to remove solutes from solution (Bouwer, 1978). Specific attenuation processes include ion exchange, matrix diffusion, nonspecific electrostatic sorption, and chemical partitioning between the aqueous and mineral phases in a system (DOE, 1992b).

\subsubsection{Exdrostrationaphy}

The Collins Ranch disposal site is underlain by up to $1000 \mathrm{ft}(300 \mathrm{~m})$ of unconsolidated to consolidated Quaternary sands, silts, and high-plasticity lacustrine clays (DOE, 1992b). Finer-grained materials predominate in the upper $150 \mathrm{ft}(46 \mathrm{~m})$, becoming coarser with depth. The depth to bedrock is undetermined, but is estimated to be greater than $1000 \mathrm{ft}(300 \mathrm{~m})$, based upon the depth of sediments along the eastern edge of Goose Lake Basin (DOE, 1985a).

Depths to ground water beneath the disposal site range from $10 \mathrm{ft}(3 \mathrm{~m}) \mathrm{bls}$ upgradient of the disposal cell to $125 \mathrm{ft}(38 \mathrm{~m})$ bls downgradient of the disposal cell. Ground water levels in the POC wells range from 96 to $120 \mathrm{ft}(27$ to 36 $\mathrm{m})$ bls. Ground water is expected to be unconfined to semiconfined within the fine silty sands and clayey silts. The Lakeview RAP (DOE, 1992b) reports an average hydraulic conductivity of approximately $0.4 \mathrm{ft} /$ day $\left(1 \times 10^{-4} \mathrm{~cm} / \mathrm{s}\right)$ calculated from five sediment slug tests conducted at the Collins Ranch disposal site.

Figure 5.1 shows a September 1992 water table contour map of this disposal site. The average linear ground water velocity beneath the disposal site was estimated to range from 10 to 20 feet per year $(\mathrm{ft} / \mathrm{yr})\left(2 \times 10^{-5}\right.$ to $3 \times 10^{-5}$ $\mathrm{cm} / \mathrm{s})$, assuming an average hydraulic conductivity of $0.4 \mathrm{ft} / \mathrm{day}\left(1 \times 10^{-4} \mathrm{~cm} / \mathrm{s}\right)$, a hydraulic gradient of 0.01 , and an effective porosity of 0.15 . Ground water in the (lacustrine) aquifer flows primarily to the southeast.

The ground water flow direction and the lack of seasonal fluctuations in static water levels show that recharge to the ground water system occurs predominately in the Fremont Mountains to the west, with little water recharging through on-site soils (DOE, 1992b). Site-specific soil and pore fluid data indicate that any recharge moves through thin, continuous lenses and stringers of silty sand, rather than uniformly through the soil horizon.

Ground water discharges to surface drainages southeast of the site, ultimately to Goose Lake. In addition, ground water may be discharged to heavily pumped irrigation wells (DOE, 1992b). 
The Collins Ranch disposal site is located adjacent to a drainage divide along the southwestern slopes of Augur Hill (Figure 5.2). The drainage area above the disposal cell (approximately 15 ac [6 ha]) drains southwest toward Camp Creek. Located approximately $3000 \mathrm{ft}(900 \mathrm{~m})$ to the southwest and $50 \mathrm{ft}(15 \mathrm{~m})$ below the site, Camp Creek has a drainage area of approximately 8300 ac (3400 ha). Camp Creek drains into the east branch of Thomas Creek approximately $6.5 \mathrm{mi}(10 \mathrm{~km})$ southeast of the site.

During construction, two seeps were identified along the exposed surface of the disposal cell excavation slopes in the spring of 1987 (Figure 5.2). No evidence of these seeps has been reported since that time.

\subsubsection{Backoround around water ouslity}

The Lakeview permanent site file contains historical background ground water quality data for the lacustrine aquifer underlying the Collins Ranch disposal site (collected from September 1986 to August 1993). Detailed information about the background monitor wells is provided in the Lakeview RAP (DOE, 1992b).

Background ground water in the uppermost (lacustrine) aquifer is characterized as calcium-bicarbonate. Total dissolved solids (TDS) in the uppermost aquifer range from 92 to 252 milligrams per liter $(\mathrm{mg} / \mathrm{L})$. The $\mathrm{pH}$ ranges from 5.83 to 8.24 and the Eh is generally oxidizing.

During the disposal site characterization described in detail in the Lakeview RAP (DOE, 1992b), background ground water quality was analyzed for hazardous constituents listed in 52 FR 36000 . MCLs for ground water, proposed by 52 FR 36000, are listed in Table 5.1.

\subsubsection{Monitored constituents and concentration limits}

Ground water monitoring and pore fluid sampling was conducted for site characterization before and during remedial action construction. Ground water compliance monitoring continued after surface remediation construction activities were complete. The Lakeview RAP (DOE, 1992b) describes the tailings materials and evaluates the tailings pore fluid solution. Table $\mathbf{5 . 2}$ summarizes regulated hazardous constituents in background ground water, tailings pore fluids, POC concentrations, and the MCLs. Several constituents listed in Table $\mathbf{5 . 2}$ are not considered hazardous constituents of concern because their average concentrations in the tailings pore fluid are less than their respective detection limits and/or MCLs. These constituents are barium, chromium, lead, molybdenum, nitrate, selenium, and silver. As a result, these constituents will not be monitored as part of the long-term surveillance program. 


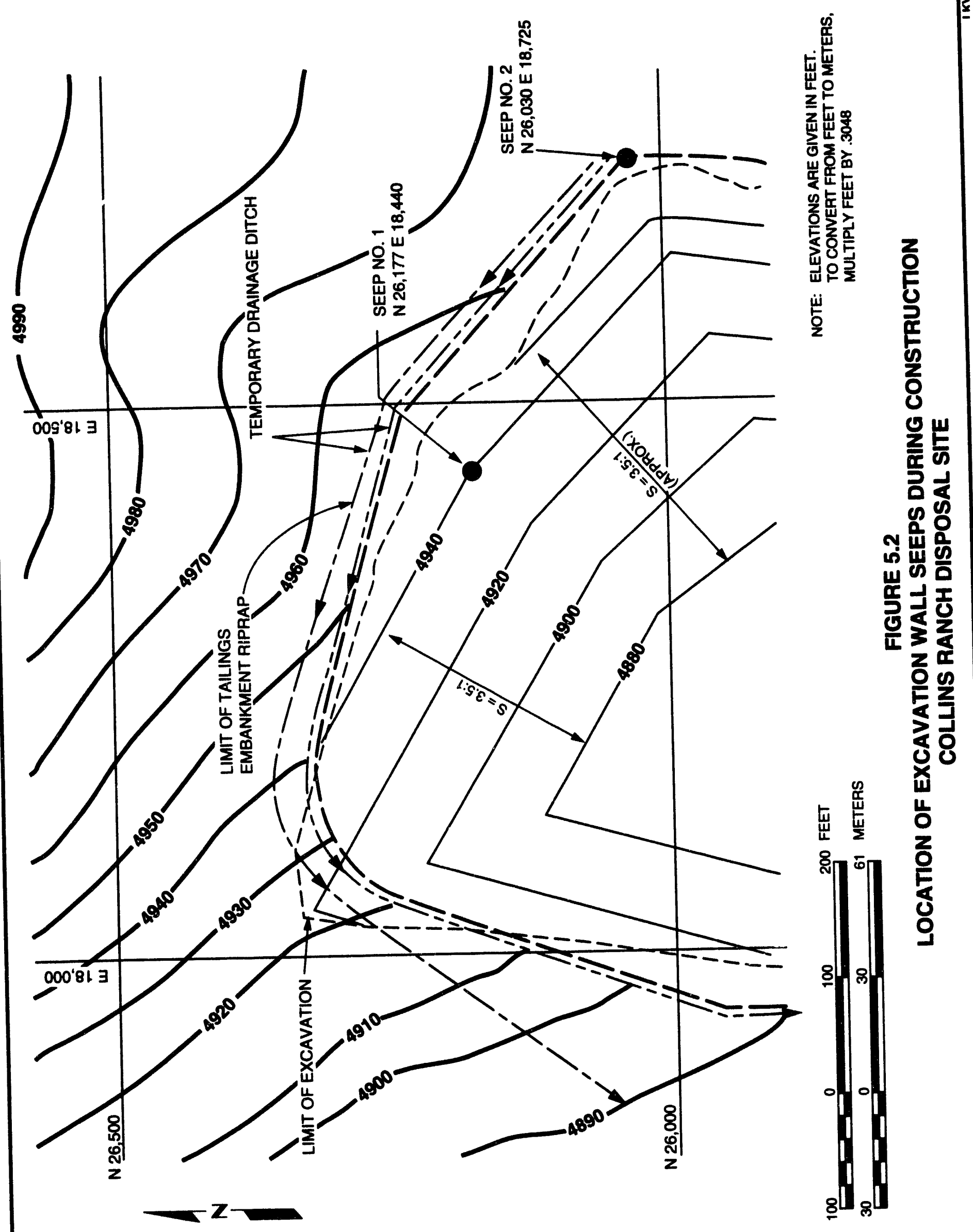


Table 5.1 Maximum concentration limits for ground water protection (52 FR 36000)

\begin{tabular}{|c|c|}
\hline Inorganic constituent & Maximum concentration Umit $(\mathrm{mg} / \mathrm{L})$ \\
\hline $\begin{array}{l}\text { Arsenic } \\
\text { Barium } \\
\text { Cadmium } \\
\text { Chromium } \\
\text { Lead } \\
\text { Mercury } \\
\text { Molybdenum } \\
\text { Nitrate (as nitrogen) } \\
\text { Selenium } \\
\text { Silver }\end{array}$ & $\begin{array}{l}0.05 \\
1.0 \\
0.01 \\
0.05 \\
0.05 \\
0.002 \\
0.1 \\
10.0 \\
0.01 \\
0.05\end{array}$ \\
\hline Radiological constituent & Concentration (pCi/L) \\
\hline $\begin{array}{l}\text { Combined Ra (Ra-226 and }-228 \text { ) } \\
\text { Combined uranium (U-234 and }-238 \text { ) } \\
\text { Gross alpha (excluding radon and } U \text { ) }\end{array}$ & $\begin{array}{c}5.0 \\
30.0(0.044 \mathrm{mg} / \mathrm{L}) \\
15.0\end{array}$ \\
\hline
\end{tabular}

- pCir = picocuries per liter.

Table 5.2 Summary of hazardous constituents identified in the Lakeview tailings pore fluid, maximum background, POC wells, and proposed EPA MCLs

\begin{tabular}{|c|c|c|c|c|}
\hline Constituent & $\begin{array}{c}\text { Maximum } \\
\text { observed } \\
\text { background }\end{array}$ & $\begin{array}{l}\text { Tailings pore } \\
\text { fluid average } \\
\text { concentration }\end{array}$ & $\begin{array}{c}\text { POC wolls } \\
\text { average } \\
\text { concentrationc }\end{array}$ & $\begin{array}{l}\text { Proposed EPA } \\
\text { MCL }^{d}\end{array}$ \\
\hline Arsenic & 0.08 & 0.147 & 0.008 & 0.050 \\
\hline Barium & 0.1 & $<0.10$ & 0.01 & 1.00 \\
\hline Cadmium & $<0.01$ & 0.03 & $<0.001$ & 0.010 \\
\hline Chromium & 0.01 & 0.01 & $<0.01$ & 0.050 \\
\hline Lead & 0.01 & $<0.01$ & 0.005 & 0.050 \\
\hline Mercury & 0.0003 & Not measured & $<0.0002$ & 0.002 \\
\hline Molybdenum & 0.07 & 0.04 & $<0.01$ & 0.100 \\
\hline Nitrate (as $\mathrm{NO}_{3}$ ) & 2 & 17 & 3 & 44.0 \\
\hline Selenium & 0.03 & $<0.005$ & 0.0025 & 0.010 \\
\hline Silver & $<0.01$ & $<0.01$ & $<0.01$ & 0.050 \\
\hline Uranium-234/238 & 0.004 & 0.048 & 0.001 & 0.044 \\
\hline Radium-226/228 & $<2$ & Not measured & 0.6 & $5.0^{\circ}$ \\
\hline Net gross alpha० & Not reported & Not measured & 0.21 & $15.0^{\circ}$ \\
\hline
\end{tabular}

- Constituent values are reported as $\mathrm{mg} / \mathrm{L}$ unless otherwise noted.

bValues are from Lakeview RAP (DOE, 1992b), Vol. II, Table F.4.1.

'Statistical average values (mean or medium) are calculated from the Data Analysis and Retrieval

Tools (DART) data base for the POC monitor wells (September 1990 to September 1992)

(DOE, 1992d).

${ }^{d} 52$ FR 36000.

- Values reported as pCi/L. 
Gross alpha and Ra-226 and Ra-228 activities were not measured in the tailings pore fluid solution. As reported in the Lakeview RAP (DOE, 1992b), Ra-226 and Ra-228 activities were not measured in the tailings pore water because of the large sample volume required for the analysis. The maximum observed activity in the shallow ground water beneath the processing site was reported as less than 2 picocuries per liter $(\mathrm{pCi} / \mathrm{L})$ in the Lakeview RAP. Shallow ground water measurements were considered to be representative of the source activity for Ra-226 and Ra-228. Furthermore, the average activities of gross alpha and Ra-226 and Ra-228 are in the same range as background in ground water samples collected from shallow on-site and downgradient monitor wells. As a result, net gross alpha and Ra-226 and Ra-228 are not considered potential hazardous constituents of concern at the Collins Ranch disposal site. Uranium was detected in the tailings pore fluid solution above the MCLs and is expected to be the most mobile radionuclide in solution. Therefore, continued monitoring for uranium (instead of net gross alpha and Ra-226 and Ra-228) will ensure that the disposal cell is in compliance.

In summary, the hazardous constituents that will be monitored on a long-term basis are those with representative source term concentrations exceeding the proposed EPA MCLs in the tailings pore fluids at the processing site: arsenic $(0.147 \mathrm{mg} / \mathrm{L})$, cadmium $(0.03 \mathrm{mg} / \mathrm{L})$, and uranium $(0.048 \mathrm{mg} / \mathrm{L})$.

Some trace constituents historically reported as only slightly above, at, or below the detection limits will be eliminated from the long-term surveillance program. These constituents include aluminum, ammonium, antimony, barium, beryllium, boron, bromide, chromium, cobalt, copper, cyanide, fluoride, lead, mercury, molybdenum, nickel, nitrate, phosphate, selenium, silver, strontium, Ra-226 and Ra-228, gross alpha, gross beta, sulfide, thallium, thorium, tin, vanadium, zinc, and total kjeldahl nitrogen. Table 5.3 lists the constituents recommended for long-term monitoring.

Table 5.3 List of constituents recommended for long-term monitoring at the Collins Ranch disposal site

\begin{tabular}{|c|c|c|c|}
\hline $\begin{array}{l}\text { Hazardous } \\
\text { constituents }\end{array}$ & Major ions & Indicator constituents & Field parameters \\
\hline $\begin{array}{l}\text { Arsenic } \\
\text { Cadmium } \\
\text { Uranium }\end{array}$ & $\begin{array}{l}\text { Calcium } \\
\text { Chloride } \\
\text { Magnesium } \\
\text { Potassium } \\
\text { Sodium } \\
\text { Sulfate }\end{array}$ & $\begin{array}{l}\text { Iron } \\
\text { Manganese } \\
\text { Silica } \\
\text { Total dissolved solids }\end{array}$ & $\begin{array}{l}\text { Alkalinity } \\
\text { Specific conductivity } \\
\text { Oxidation/reduction potential } \\
\text { pH } \\
\text { Temperature }\end{array}$ \\
\hline
\end{tabular}


The EPA has established MCLs for all hazardous constituents of concern for the Lakeview tailings pore fluid solution. Therefore the MCLs, rather than the statistical background concentrations, are the remedial action compliance levels.

Historical ground water quality data for the POC and downgradient monitor wells (June 1980 to August 1993) are available in the Lakeview permanent site file. Concentrations or activities of all hazardous constituents measured for the POC and downgradient monitor wells generally have been below the MCLs.

\subsection{GROUND WATER MONITORING NETWORK}

The Lakeview RAP (DOE, 1992b) recommended monitoring background monitor wells, POC monitor wells, and downgradient monitoring wells. However, only 9 of the 16 monitor wells sampled in the past will be in the long-term surveillance program. Justification for modifying the ground water monitoring network is provided below.

The ground water monitoring network for the Collins Ranch disposal site has been modified to consist of one upgradient (background) monitor well (515) and eight POC monitor wells (602 through 609). These wells are screened in the uppermost aquifer at the disposal site. Figure $\mathbf{5 . 3}$ shows the locations of these wells. Monitor well completion reports and lithologic logs are kept in the Lakeview permanent site file.

Three additional background monitor wells farther upgradient from the disposal cell and four wells downgradient of the POC monitor wells will be eliminated from the long-term surveillance program. These additional background wells will not be monitored because the background historical data base has been sufficiently characterized. The four downgradient wells will not be monitored because the eight POC wells provide sufficient coverage for compliance monitoring.

Ground water level and quality data for the upgradient and POC monitor wells will be provided to comply with the disposal cell performance evaluation presented in the Lakeview RAP (DOE, 1992b). Historical ground water level and quality data will be reviewed at least every 5 years to evaluate the performance of the ground water monitoring network.

\subsubsection{Direct monitoring network}

Direct monitoring of the uppermost aquifer is required under 52 FR 36000 . Eight POC monitor wells (602 through 609) measure ground water quality and static water levels at the POC, directly downgradient of the disposal cell in the lacustrine (uppermost) aquifer (DOE, 1992b). These eight wells are located approximately $50 \mathrm{ft}(15 \mathrm{~m})$ downgradient of the disposal cell. Placement of the POC monitor wells optimizes early detection of any hazardous constituents released in the uppermost aquifer without disturbing the design components of the cell. As shown in Figure 5.3, the eight POC monitor wells have been placed 


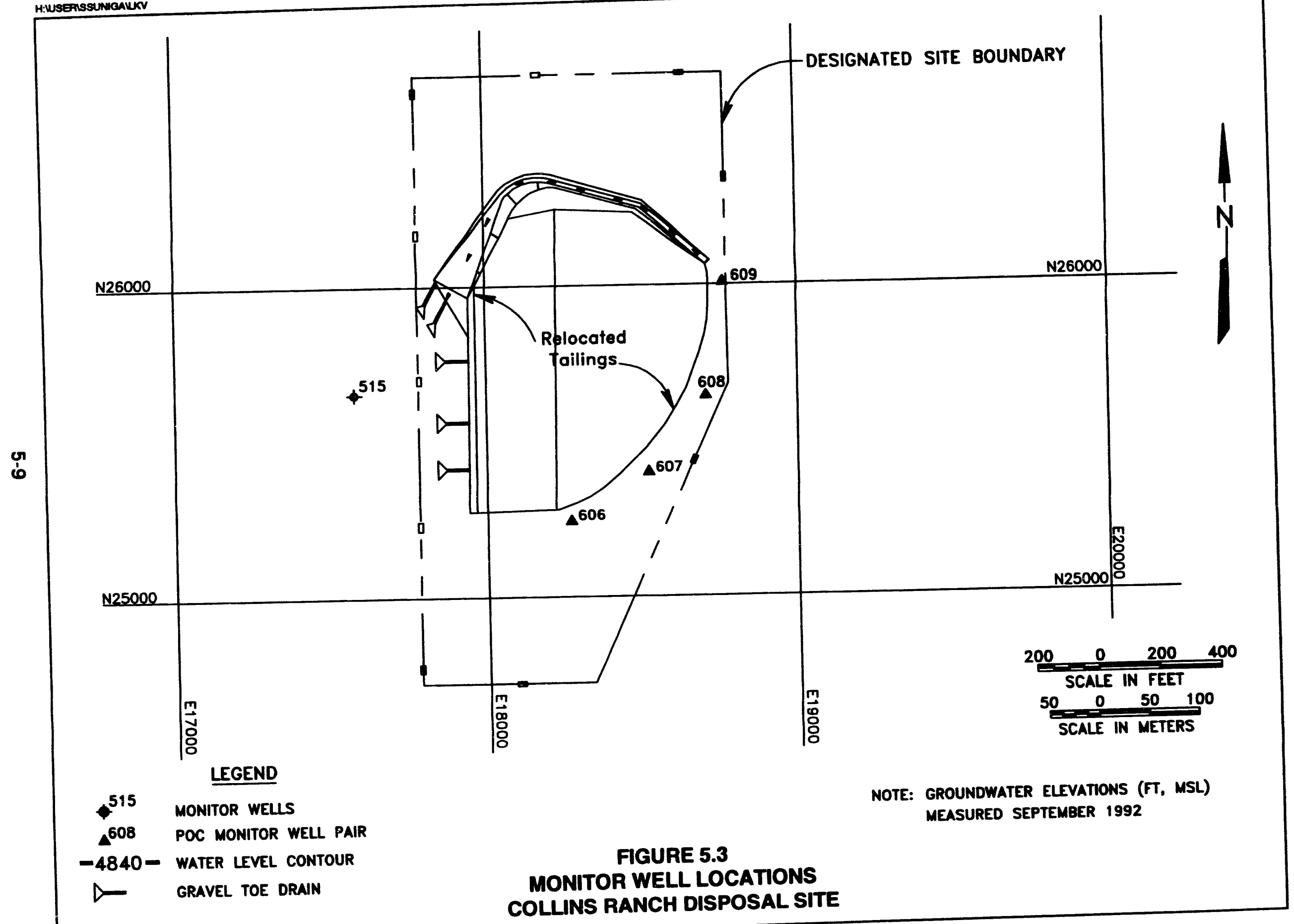


in four monitor well clusters. Each cluster consists of two wells: a shallow well screened at approximately $100 \mathrm{ft}(30 \mathrm{~m}) \mathrm{bls}$, and a deeper well screened at approximately $150 \mathrm{ft}(46 \mathrm{~m})$ bls. Reportedly, the shallow wells in each cluster have been dry at various times in the past. Ground water monitoring will continue at all POC wells to comply with the disposal cell performance evaluation presented in the Lakeview RAP (DOE, 1992b); the monitoring plan will be reviewed every 5 years to evaluate the ground water monitoring network's effectiveness.

One upgradient background monitor well (515) will be sampled to detect regional changes in geochemistry over time. This well is screened in the uppermost aquifer within the same formation and at approximately the same depths as the shallow POC monitor wells.

Ground water levels will be measured in each well before water quality samples are collected. The resulting water-level data will be examined periodically to estimate the ground water flow rate and direction and to ensure that no significant hydrologic change has occurred that could affect ground water monitoring.

\subsubsection{Monitor well installation and development}

All monitor wells were installed and developed in accordance with TAC/UMTRA Project Office Standard Operating Procedures (SOP) (JEG, n.d.) 16.1.1 and 16.1.2, on file at the DOE Albuquerque Operations UMTRA Project Office, Albuquerque, New Mexico (Attachment 5). These SOPs are consistent with the RCRA Ground Water Monitoring Technical Enforcement Guidance Document (EPA, 1986), ensuring that representative ground water samples are retrieved.

Specific information regarding monitor well installation and development is presented in the Lakeview RAP (DOE, 1992b). Monitor well completion reports are provided in the Lakeview permanent site file.

\subsubsection{Indirect monitoring network}

Indirect monitoring for the Collins Ranch disposal site is not necessary because the direct ground water monitoring network described in Section 5.2.1 is sufficient to provide early detection of hazardous constituents released from the disposal cell or notable changes in background ground water quality.

\subsection{GROUND WATER MONITORING PROGRAM}

The ground water monitoring program is designed to demonstrate that the initial performance of the disposal cell follows the design requirements. The program will monitor the uppermost aquifer, analyzing ground water samples from monitor wells at the POC and upgradient from the disposal cell. This direct monitor well network is discussed in Section 5.2.1 of this report. Performance monitoring frequency is outlined in Section 5.3.1 of this report. Table 5.3 lists the constituents that will be monitored. 
the constituents that will be monitored.

All aspects of the ground water monitoring program will be conducted in accordance with accepted industry QA practices, including directives in DOE Orders 5700.6C, Quality Assurance, and 5400.1, General Environmental Protection Program. The general sequence of the ground water monitoring program is provided in Figure 5.4.

\subsubsection{Sampling frequency}

The sampling scheduls accounts for such factors as background ground water quality, geochemistry of the tailings pore fluid solution, horizontal and vertical ground water flow rates, the possibility of seasonal variations in ground water, and risk to human health and the environment. The Lakeview RAP (DOE, 1992b) details these factors. Samples have been collected either quarterly or semiannually since construction of the disposal cell. The recommended longterm sampling frequency is once every 5 years. Sampling will be conducted in late summer to maintain a consistent record in the historical data base.

The reasons for this change in recommended sampling frequency (once every 5 years) are based upon the time it would take for any potential seepage from the disposal cell to reach the water table, the low horizontal linear ground water flow velocity, the limited water use in the area, and the current and historical water quality conditions at the site. These factors are discussed below. (Response to NRC Comment \# 18)

The rate and nature of ground water recharge at the Collins Ranch disposal site were characterized with laboratory hydraulic tests on soil samples, suction measurements at a nest of tensiometers, and tritium analyses (DOE, 1985b). These tritium analyses, conducted in 1984 as part of the disposal site characterization activities, were used to date the water in the vadose zone prior to surface remediation (DOE, 1985b; 1992b). One surface water sample and three pore fluid samples (collected from lysimeters at depths of 4,10 , and $30 \mathrm{ft}$ $[1,3$, and $9 \mathrm{~m}]$ ) were analyzed for tritium. Using tritium concentrations at the three depths relative to tritium concentrations of the nearby surface water sample, the estimated travel times were at least 2 years for a 4-ft $(1-\mathrm{m})$ depth, at least 5 to 6 years for a 10-ft $(3-\mathrm{m})$ depth, and at least 30 years for a $30-\mathrm{ft}$ $(9-\mathrm{m})$ depth. Based on these analyses, and the assumption of vertical seepage through a porous medium, the projected travel time of the tailings fluid ranges from less than 1 to $2 \mathrm{ft} / \mathrm{yr}(0.3$ to $0.6 \mathrm{~m} / \mathrm{yr})$. The depth to the water table at the POC ranges from 96 to $120 \mathrm{ft}(27$ to $36 \mathrm{~m})$. Therefore, based upon the projected travel time, any potential seepage from the disposal cell would not reach the water table at the POC for at least 50 years, and more likely for 100 years.

The average horizontal linear ground water velocity beneath the disposal site was estimated to range from 10 to $20 \mathrm{ft} / \mathrm{yr}(3 \mathrm{to} 6 \mathrm{~m} / \mathrm{yr}$ ) (Section 5.1.1). Ground water is not currently used in the immediate vicinity of the Collins Ranch disposal site. A water use survey previously identified two private wells located 


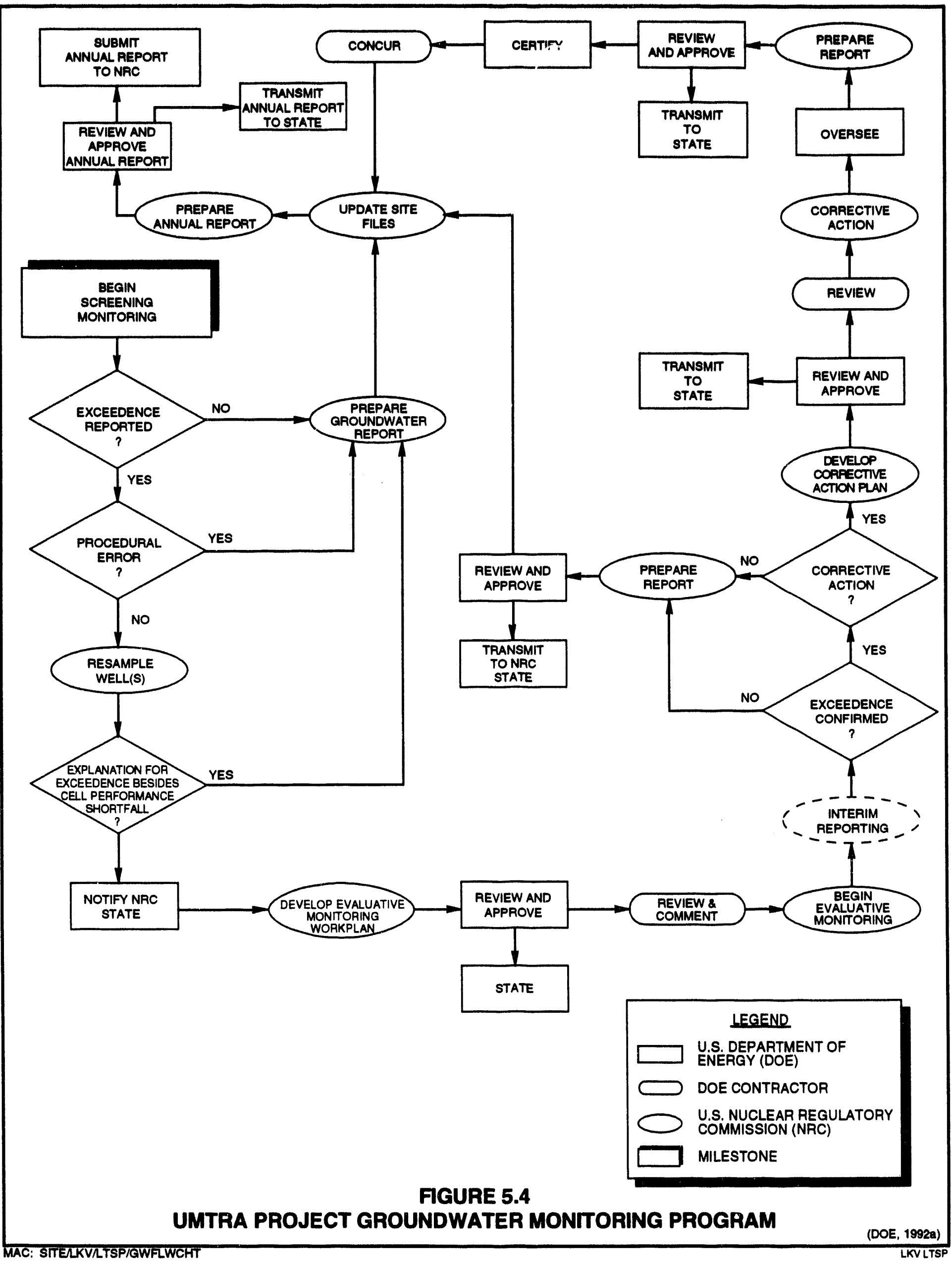


approximately 1.3 to $1.5 \mathrm{mi}(2.1$ to $2.4 \mathrm{~km})$ from the site (DOE, 1985b; 1992b). The subsurface lacustrine sediments are expected to have similar lithologic and hydraulic properties regionally (DOE, 1985b). If any potential seepage from the disposal cell reached the water table, its lateral movement would be so slow that it would take more than 250 years to move the $1 \mathrm{mi}$ $(1.6 \mathrm{~km})$ to the closest well.

A 1993 statistical analysis compared the quality of background ground water at the disposal site to that of semples from the POC. No statistically significant changes were noted between water quality upgradient of the disposal cell and that at the POC since the POC wells have been in place. The results of this statistical analysis are on file in the UPDCC. Albuquerque UMTRA Project Office.

The recommended frequency of long-term sampling depends in part on the effectiveness of the remedial action as determined through the ongoing monitoring program (EPA, 1988). As necessary, the DOE will apply the observational method, using ground water monitoring data, to evaluate disposal cell performance and to modify remedial actions. The observational method has been applied to remedial investigation/feasibility studies and remedial design/remedial action projects under the Superfund process; Comprehensive Environmental Response, Compensation, and Liability Act (CERCLA); and Superfund Amendments and Reauthorization Act as a streamlined approach (EPA, 1989a). The observational method uses monitoring data to evaluate whether remedial action objectives are met and the remedial action is complete (EPA, 1988).

Performance evaluations will be conducted once every 5 years to determine the following:

- Effectiveness of the disposal cell ground water compliance strategy.

- Effectiveness of the ground water monitoring plan (i.e., ground water monitor well network, sampling frequency, analytes measured).

- Need for continued monitoring.

This approach will provide the flexibility necessary to respond to new information and changing conditions. Performance evaluation reports will be presented to the NRC and the state of Oregon for comments. The statistical methods described in the EPA's Statistical Analysis of Ground Water Monitoring Data at RCRA Facilities - Interim Final Guidance (EPA, 1989b) or other appropriate methods will be applied, as necessary.

\subsubsection{Screening monitoring and exceedance validation}

The EPA has defined MCLs for all hazardous constituents of concern at the Collins Ranch disposal site. As shown in Table 5.2, statistical maximum values of background ground water quality for the hazardous constituents are less than the EPA MCLs. The EPA MCLs are the established exceedance criteria for the 
During the established ground water monitoring period (specified in Section 5.3.1), screening monitoring will be conducted to observe possible changes in ground water quality and to assess cell performance. Screening monitoring involves routine water-quality data collection, data evaluation, and possible resampling. Exceedances in concentration limits are evaluated on a well-by-well and analyte-by-analyte basis. If an MCL presented in Tabie 5.1 is exceeded, the appropriate steps will be taken, as specified in Section 5.3.2 of the Guidance for Implementing the UMTRA Project Long-term Surveillance Program (DOE, 1992a).

\subsubsection{Evaluativemonitoring}

When sampling, evaluation, and resampling during screening monitoring cannot rule out the disposal cell as the cause for a water-quality exceedance, additional field and evaluation work (evaluative monitoring) may be required. To determine with greater surety if the disposal cell is the cause, and if so, the nature and extent of the exceedance. Evaluative monitoring will involve the procedures described in Section 5.3.3 of the Guidance for Implementing the UMTRA Project Long-term Surveillance Program (DOE, 1992a).

\subsubsection{Indireat monitoring}

Indirect monitoring is not necessary for the Collins Ranch disposal site. Direct monitoring is considered sufficient to provide early detection of hazardous constituents released from the disposal cell and will detect notable changes in background ground water quality as described in Section 5.2.1.

\subsection{CORRECTIVE ACTION}

The EPA's proposed standards (52 FR 36000) require a corrective action program to be implemented within 18 months of verification of an established concentration limit exceedance for one or more of the monitored constituents. The goal of the corrective action program is to restore the disposal cell to its design requirements. NRC regulations (10 CFR 40.27(C)(5)) specify that the DOE will notify the NRC before implementing any significant corrective action. Section 9.0 provides guidance for implementing a corrective-action program.

If corrective action is determined necessary, the DOE will prepare and submit a corrective action plan for NRC review (a copy of this plan also will be transmitted to the state of Oregon). The plan will include a monitoring program to demonstrate the effectiveness of the corrective action, which the DOE will implement after consultation with the NRC and the state of Oregon. 
As a part of evaluative monitoring, a risk assessment may be conducted to evaluate the potential harm from the exceedance to human health or the environment. If the risk assessment demonstrates no potential harm exists, the corrective action may involve no action except continued monitoring.

\section{B.8 DATA VALIDATION AND QUALITY ASSURANCE}

The UMTRA Project has established SOPs for monitor well installation development, water sampling, preservation and transport, field procedures, and chain of custody.

QA, quality control (QC), analytical data management, and validation will be detailed in the Quality Assurance Implementation Plan being developed in accordance with DOE Order 5700.6C, Quality Assurance.

Compliance ground water monitoring at the Collins Ranch disposal site will remain the responsibility of the UMTRA Project Office until the site comes under the NRC general license. Until licensing, all aspects of ground water monitoring will be conducted in accordance with these procedures and will be updated regularly to reflect changes in industry standards, best management practices, or EPA guidance. The QA procedures described in this section are consistent with the RCRA Ground Water Monitoring Technical Enforcement Guidance Document (EPA, 1986).

At licensing, the responsibility for ground water monitoring at the Collins Ranch disposal site will be transferred to the GJPO. The GJPO will then be responsible for implementing procedures and developing a QA/QC program consistent with EPA guidance and DOE Orders (Section 12.0).

Sections 5.6.1 through 5.6.4 in the Guidance for Implementing the UMTRA Project Long-term Surveillance Program (DOE, 1992a) summarize standard QA procedures for water sampling and analytical QC, QA, and data validation.

\subsection{REPORTING}

Data and results of the ground water monitoring program will be reported once every 5 years, when the POC and background monitor wells are sampled. The following information will be included in the 5-year performance evaluation reports:

- A table of concentration limits for hazardous constituents.

- A table comparing water quality data to concentration limits.

- A summary of any exceedances of concentration limits. 
- Water-quality or water-level data (and indirect monitoring data, if they become necessary for evaluative monitoring).

- A summary of any resampling, trends, exceedances, evaluative monitoring, or corrective action required during the reporting period.

- Any significant trends or anomalies in the water-quality and water-level data. The narrative will compare collected data to preestablished baseline values.

- Any significant changes in local hydrology.

- The analytical methods used to interpret water quality or indirect monitoring data trends.

- The qualitative or statistical procedure selected to compare ground water quality results with preestablished baseline values.

- A discussion of any new wells or indirect monitoring stations installed, including the rationale for their installation and all completion data.

- All completed field and laboratory forms.

In addition, the 5-year performance evaluation reports will evaluate the effectiveness of the disposal cell. At a minimum, the reports will also do the following:

- Review historic screening compliance monitoring data.

- Summarize trends in water levels and water quality.

- Include a statistical analysis of historical data, as necessary.

- Evaluate the effectiveness of the disposal cell.

- Determine the effectiveness of the ground water monitoring plan and whether or not the plan should be modified.

- Determine whether remedial action is complete.

The UMTRA Project Office will submit these reports to the NRC and the state of Oregon in compliance with the environmental monitoring requirements of DOE Order 5400.1. All ground water monitoring data and supporting documentation will be part of the permanent site file. The UMTRA Project Office will be responsible for preparing these reports until responsibility for the site is completely transferred to the GJPO. 


\subsection{SITE INSPECTIONS}

Inspections of the Collins Ranch disposal site will result in preparation of a status report to record any changes to the disposal cell and site over time and to identify potential problems before the need for extensive maintenance, repairs, or corrective action. Fundamental to the inspections will be the detection and documentation of progressive change caused by slow-acting natural processes. The findings from these inspections will be compared to the initial baseline conditions to provide a basis for future inspections. The three types of site inspections are:

- Annual or scheduled site inspections.

- Follow-up inspections.

- Contingency inspections.

Each site inspection must be documented in a report that identifies the findings of the inspection. Copies of the report will be submitted to the NRC and the state of Oregon and will be placed in the Lakeview permanent site file. Annual or scheduled site inspection reports will be completed and submitted to the NRC withir: 90 days of the last UMTRA program site inspection of that calendar year. Follow-up or contingency inspection reports must be submitted to the NRC within 60 days of the initial report and within 60 days after any other type of inspection.

In addition, the rooting patterns of plants growing on the tailings pile have been monitored annually since 1991. Results of the 1991 and 1992 surveys appear in a paper published by Burt and Cox (1993). The results of the 1993 survey are in unpublished field notes archived in the UPDCC, Albuquerque UMTRA Project Office.

\section{1}

\section{INSPECTION FREQUENCY}

The Collins Ranch disposal site will be inspected annually for the first 5 years after licensing. At the end of the 5-year period, the GJPO will evaluate the need to continue annual inspections, basing its recommendation on an evaluation of the annual reports and any other reports filed for maintenance or unscheduled events. If it is determined that less frequent inspections are required, the GJPO will modify the LTSP and submit it to the NRC for approval. The state of Oregon will also receive copies for review. Subsequent inspections will be considered a schsduled site inspection.

\subsection{INSPECTION TEAM}

The inspection team will consist of a chief inspector and one or more assistants. The chief inspector will be a geotechnical engineer, a civil engineer, or an engineering geologist knowledgeable in processes that could adversely affect the site (e.g., geomorphic agents of change). 
When they are needed for follow-up or assessment inspections, the team will include additional technical experts appropriate to the problems under investigation.

\subsection{PREPARATION FOR INSPECTION}

Before each inspection, inspectors will complete the following tasks:

- Review the final LTSP, the permanent site file, the previous site inspection reportis! and site inspection map(s), and all maintenance or corrective action reports.

- Prepare the site inspection checklist based on previous inspections or repairs; incorporate any needed modifications.

- Verify and update the names and telephone numbers of all parties with whom access or notification agreements have been executed.

- Verify the DOE 24-hour telephone number and appropriate agency telephone numbers and contacts; arrange to modify the entrance sign, as needed.

- Schedule the site inspection.

- Assemble all equipment needed for the inspection.

- Adjust the Brunton compass's magnetic declination for that of the Lakeview area (currently approximately 20 degrees east of north).

- Notify the NRC, the state of Oregon Department of Environmental Quality Land Use Division, and adjacent land owners for their possible attendance at the inspection. Names and addresses of adjacent land owners are provided in the Lakeview permanent site file at the GJPO. An index of the Lakeview permanent site file is provided in Attachment 3.

\subsection{SITE INSPECTION AND INSPECTION CHECKLIST}

The site inspection will cover the disposal site area, the disposal cell, and the immediate off-site areas. All site inspection activities and observations should be recorded and described using the as-builts, initial site inspection checklist (Attachment 6), site inspection map, a field notebook, and photographs. Observations and photographic stations should be recorded on the field maps. After the inspection is complete, these maps should be drafted and kept in the permanent site file.

The initial site inspection checklist (Attachment 6) is a guideline for the inspectors. After each inspection is complete, the checklist will be revised to include new information or to delete items that are no longer pertinent. Revisions to the checklist will be documented in the inspection report. 
A photographic record of the site inspection must be maintained. Site conditions should be documented by ground photographs to record developing trends and to enable the DOE to evaluate the need for and extent of future activities. If possible, any site feature or condition requiring inspectors to make a written comment, explanation, or description will be photographed. A site inspection photo log will be used to record the photographs (Attachment 4). All features will be photographed and recorded as specified in Section 3.5. The inspectors may determine the number of photographs, the view angles, and the lenses used to ensure that sufficient photographs are taken for agency review.

\subsubsection{Off-rite areas}

The area within a maximum of $0.25 \mathrm{mi}(0.4 \mathrm{~km})$ of the center of the disposal site will be surveyed for evidence of land-use changes that indicate increased human activity (i.e., greater probability of intrusion onto the site). New roads or paths, changes in vegetation, and relevant geomorphic features like gullies or aeolian formations, any of which could initiate site-threatening erosion, will also be observed.

\subsubsection{On-site areas}

The integrity of the disposal cell site will be evaluated from a series of transects around its perimeter, along its base, crest, and sideslopes, of the disposal cell and in and around the diversion channels. Sufficient transects must be walked so that the disposal site area is thoroughly covered and inspected. Diagonal transects of the crest will be made, and the edge of the crest will be walked. Additional transects, at approximately 50-yd $(46-\mathrm{m})$ intervals, will be walked along the sideslopes. Transects along the entire length of each diversion channel will be made to determine whether the channels have been functioning and can be expected to continue to function as designed.

At minimum, the site perimeter and site area transects will be monitored for damage to or disturbance of the following features:

- Fences, gates, and locks.

- Permanent site-surveillance features.

- Ground water monitor wells.

- Site area vegetation or volunteer plant growth.

- Sedimentation or erosion.

The complete length of transects along the engineered component (diversion channels, cell sideslopes, cell crest, and cover) will be walked and examined for evidence of the following:

- Structural instability resulting from differential settlement, subsidence, cracking, sliding, or creep.

- Erosion as evidenced by developing rills or gullies. 
- Sedimentation or debris.

- Rapid rock cover deterioration caused by weathering or erosion.

- Removal of rock or other disposal cell material.

- Seepage.

- Intrusion (inadvertent or deliberate) by humans or animals.

- Animal burrowing.

- Vandalism.

- Trails showing human or animal activity.

- Volunteer plant growth.

\subsection{MODIFYING PROCESSES}

Modifications from natural processes are most likely on the topslopes and the lower portions of the sideslopes of the disposal cell and near the diversion channel. Soil undercutting at the disposal cell toe, sheet flow erosion or gully formation at the diversion ditch outlet, and vegetation destruction of vegetation on the disposal cell topslope are of specific concern at this disposal site. Plant and animal intrusion can also cause modifications to engineered components of the disposal cell: The inspection report will detail any observed modifying features, and will include a description of the problem, relevant measurements and photographs, and an assessment of possible impacts. The description of the modifying process will include information such as the following:

- Extent of area affected.

- Number of features (e.g., gullies), and spacing, length, depth, and width.

- Patterns of occurrence.

- Species present, if plant or animals are found at the site.

- Location and density of volunteer plant growth.

Inadvertent or casual intrusion by humans or animals is not of great concern, but evidence of cover removal, extensive vandalism to signs and monuments, or the presence of well-established trails will be described in detail. Continued vandalism may require more active measures to control site access.

If new conditions requiring monitoring or immediate action are discovered during the inspection, the inspection report should include a description of the problem and the recommended follow-up action (if required). 


\subsection{VEGETATION}

\subsubsection{Planned vegetation}

The Collins Ranch disposal cell is covered with a vegetated topslope seeded during the fall of 1989 with wheatgrass (Agropyron sp.), including crested wheatgrass (A. desertorum), fescue (Festuca sp.), and big bluestem (Poa ample). Several bare areas were seeded in 1990. In 1991, an estimated 13 percent of the topslope was vegetated, with crested wheatgrass the most common species. Tumble mustard (Sisymbrium altissimum), an annual weed, was also common on the topslope (DOE, 1992e).

After licensing, a plant specialist or other qualified person will periodically participate in site inspections. If the inspection does not coincide with the general growing season, the plant specialist may conduct a separate inspection at a more favorable time. Conditions such as drought may result in a dieback of the vegetative cover. This may require reseeding, which should be coordinated with the local U.S. Soil Conservation Service agent.

\subsubsection{Volunteer plant growth}

Volunteer plant growth includes plants growing where none were planned, such as in rock-lined drainage ditches, or unwanted plant species growing on the vegetated topslope. Various plant species grow in the rock-lined ditch at the north end of the site, including wheatgrass and thistle (DOE, 1992e). A few deep-rooted plant species have invaded the vegetated topslope, including big sagebrush (Artemisia tridentata), rabbitbrush (Chrysothamnus sp.), and valley lupine (Lupinus nanus) (DOE, 1992e; TAC, 1992, 1993). In addition, tumble mustard is very common on the topslope.

A follow-up inspection by a plant specialist may be required if an inspection team reports numerous plants such as big sagebrush growing on the vegetative cover. The specialist will determine if the plant growth threatens the integrity of the disposal cell (e.g., whether roots are growing into the infiltration/radon barrier or tailings). If it is determined that plants threaten cell integrity, a vegetation control program may be instituted. A plant specialist should also inspect the disposal cell after vegetation control measures are complete, to determine the effectiveness of these measures.

\subsection{SITE INSPECTION MAP}

A new site inspection map will be prepared after each scheduled inspection using the disposal site topographic (Plate 1) map as a base. This map must include the following:

- Inspection traverses.

- Photographic locations.

- Locations and descriptions of any new, anomalous, or unexpected features. 
- Features identified during previous inspections for observation or monitoring.

- Inspection date.

\subsection{REPORTING REQUIREMENTS}

Upon completion of the field inspection, Section D of the initial site inspection checklist (Attachment 6) must be completed and the certification statement must be signed. Overlays for the as-built drawings or revised drawings will be developed, noting any potential problems or other site conditions requiring attention. The revised drawings will be labeled with the date and type of site inspection.

All photographs must be logged on a site inspection photo log (Attachment 4). A separate photo log should be completed for each roll of exposed film, with an entry for each photograph. The completed photo logs should be attached to the inspection checklist and paginated accordingly.

Documentary evidence of anomalous, new, or unexpected conditions or situations must be included to record developing trends and to enable the responsible agency to make reasonable decisions concerning follow-up inspections, custodial maintenance, repair, and corrective action. Photographs may be considered to be documentation.

A site inspection report including the following information will be completed after every routine site inspection:

- Narrative of site inspection, results, conclusions, and recommendations.

- Site inspection checklists and all relevant supporting documentation.

- Site inspection map and other drawings, maps, or figures, as required.

- Inspection photographs and photo log sheet.

- Recommendations for additional follow-up inspections, repair, or custodial maintenance, if required.

- Follow-up or contingency inspection reports, if required.

- Custodial maintenance of repair report and certification, if required.

- Inspection certification.

- Ground water monitoring data and analyses, if applicable.

Appendix A, Criterion 12 of 10 CFR 40 requires the DOE to submit results of all routine site inspections to the NRC and the state of Oregon within 90 days of the last UMTRA Project site inspection for that calendar year. A copy of all site 
inspection reports will be maintained in the permanent site file. A copy of the inspection report will also be sent to the state of Oregon. 


\subsection{UNSCHEDULED INSPECTIONS}

An unscheduled inspection may be triggered by reports or information that site integrity has been or may be compromised.

\subsection{FOLLOW-UP INSPECTIONS}

Follow-up inspections investigate and quantify specific problems found during a scheduled inspection, ground water sampling event, special study, or other DOE activity. They determine whether processes currently active on or near the site threaten site security or stability, and they evaluate the need for custodial maintenance, repair, or corrective action.

Follow-up inspections should be made by technical specialists in an appropriate discipline (e.g., a soils scientist or geomorphologist to evaluate erosion processes).

The follow-up procedure begins with an on-site visit to determine the need for definitive tests or studies. Additional visits may be scheduled if more data are needed to draw conclusions and recommend corrective action. If maintenance, repair, or corrective action is warranted, the DOE will notify the NRC, the state of Oregon, and the adjacent residents as specified in Section 9.0.

\subsection{CONTINGENCY INSPECTIONS}

Contingency inspections are unscheduled inspections ordered by the DOE when it receives information indicating that site integrity has been or may be threatened. Events that could trigger contingency inspections include severe vandalism, intrusion by humans or livestock, severe rainstorms, or unusual events such as tornados or earthquakes.

An assessment of each unusual event must be submitted to the NRC within 60 days of the initial report that damage or disruption has occurred at the Collins Ranch disposal site (10 CFR 40). The state of Oregon will receive a copy of this report. At a minimum, this report must include the following:

- A description of the problem.

- A preliminary assessment of the maintenance, repair, or corrective action required.

- Conclusions and recommendations.

- Assessment data, including field and inspection data, and photographs.

- Names and qualifications of the field inspectors. 
A copy of the report and all other data and documentation will be maintained in the permanent site file. The annual report to the NRC will include the results of these contingency inspection reports. If appropriate, the annual (or scheduled) Collins Ranch site inspection report will also contain the results of these inspections.

After reviewing the preliminary inspection/assessment report, the DOE must submit a corrective action plan for NRC approval and to the state of Oregon within the 60-day period required by 10 CFR 40 . Based on the findings of these reports, the GJPO will complete corrective action, following the guidance for implementing corrective action described in Section 9.0. 


\subsection{CUSTODIAL MAINTENANCE OR REPAIR}

Custodial maintenance will be performed as needed at the Collins Ranch disposal site; no maintenance is scheduled. Annual site inspections, follow-up inspections, and contingency inspections will determine the need for maintenance or repairs.

\subsection{PLANNED MAINTENANCE}

No routine maintenance is planned for the Collins Ranch disposal site.

\section{2}

\section{UNSCHEDULED MAINTENANCE OR REPAIR}

Unscheduled custodial maintenance required at this site may include the following:

- Repairing the gate.

- Replacing the entrance sign.

- Removing deep-rooted plants that invade the vegetated topslope of the disposal cell and infilling all animal burrows on the disposal cell.

- Reseeding the topslope if drought or other factors eliminate much of the vegetative cover.

The GJPO will prepare a purchase order statement of work (SOW) to authorize these kinds of repair. This SOW will include contractor qualifications.

If problems are identified that may affect the integrity of the disposal cell or compliance with 52 FR 36000 , the NRC must approve the recommended action in advance. The action will be treated as a corrective action.

\subsection{CERTIFICATION AND REPORTING REQUIREMENTS}

The site inspection report and the annual report to the NRC must include the following information on unscheduled maintenance or repair:

- Summary of work required.

- Work order, purchase order, or SOW.

- Contractor qualifications, if applicable.

- Contractor documentation of work completion.

- DOE certification of work completion. 
After the work is completed, the contractor must submit verification of the completed work and/or a written report if the action is considered significant. The DOE will inspect the site, as necessary, and review the report before certifying that all work is completed in accordance with all required specifications. Copies of all records, documentation, and certifications will be included in the Lakeview permanent site file. Copies of all relevant documentation will be transmitted to the state of Oregon. 


\subsection{CORRECTIVE ACTION}

If natural or unforeseen events threaten the stability of the disposal cell, corrective action could include temporary emergency measures. In addition, the DOE would evaluate the factors that caused the problem to minimize or avoid their recurrence. The following conditions could require corrective action:

- Surface rupture of the disposal cell (could indicate differential settlement or severe shrinkage of the cover materials).

- Subsidence, sliding, or slope instability on the disposal cell (caused by mass wasting, liquefaction, differential settlement, or other events).

- Development of rills or gullies on the disposal cell.

- Deterioration of the erosion protection rock on the disposal cell or in the drainage ditches.

- Seepage originating from the disposal cell or the toe of the cell.

- Gully development on or immediately adjacent to disposal site property that could affect the integrity of the disposal cell.

- Rapid headward cutting of a gully, arroyo, or ravine that threatens the stability of the disposal cell.

- Encroachment of active stream channels onto the disposal site.

- Damage to the cell cover or disposal site property because of river encroachment, extreme seismic events, extreme flooding, other catastrophic events, or vandalism (removal of cell construction materials).

- Verification of an excursion during the ground water monitoring program.

When a potential problem is identified, the DOE will notify the NRC and the state of Oregon and will submit an inspection/preliminary assessment report for NRC review no more than 60 days after the problem is identified. The preliminary assessment report will evaluate the problem and recommend the next step (e.g., immediate action or continued evaluation). After the NRC reviews the report and recommendations, the DOE will develop a corrective action plan for NRC approval. The DOE may combine the inspection and recommendation in one report, depending on the severity of the problem. Once the NRC approves the corrective action, the DOE will implement the plan. Figure 9.1 illustrates the sequence of events in the corrective action process. Figure 9.2 identifies the key elements in the corrective action process.

NRC regulations do not stipulate a time frame for implementing corrective action. However, EPA ground water regulations (40 CFR 192.02(c)) require that a corrective 


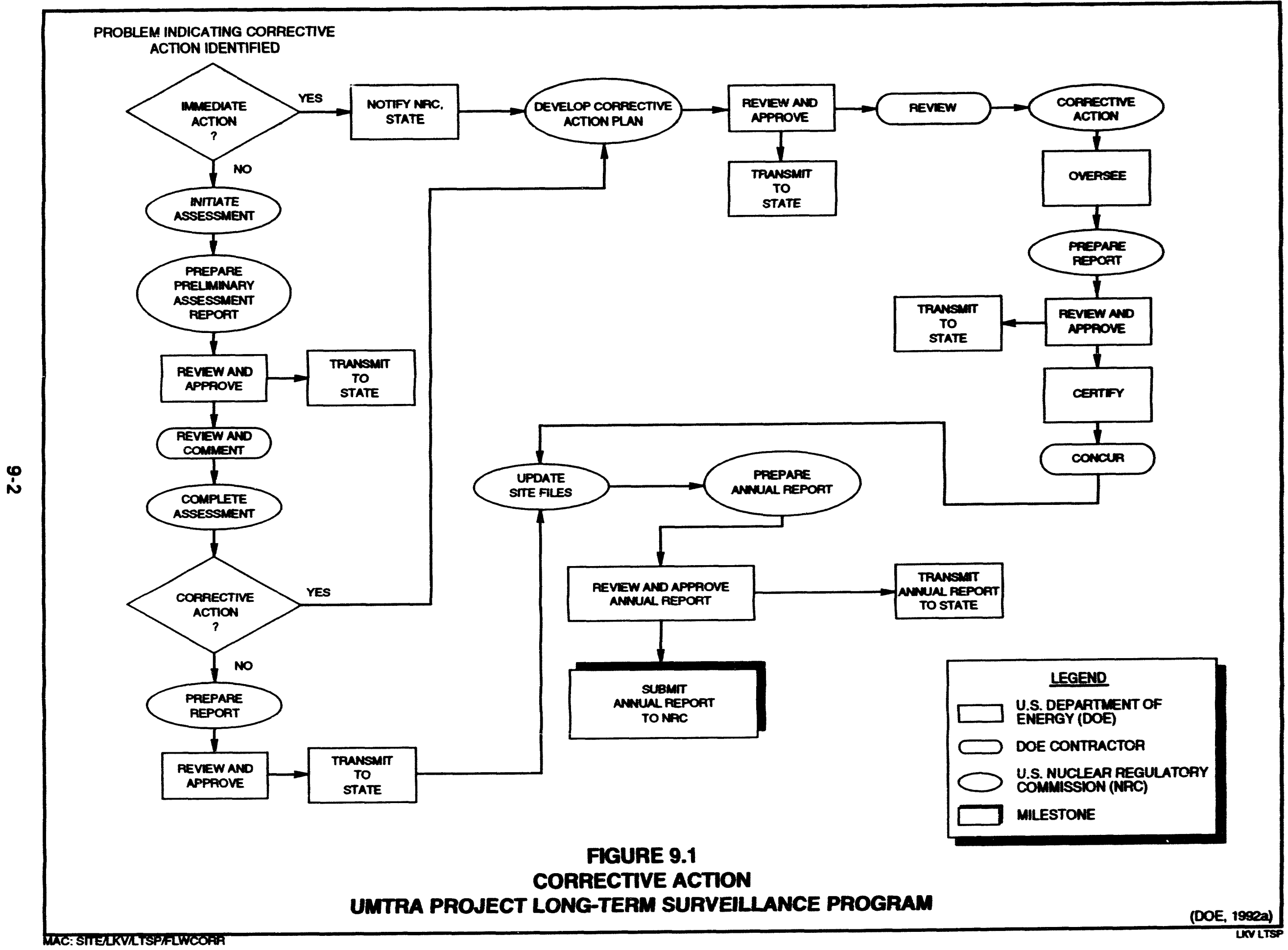




\section{NEED FOR CORRECTIVE ACTION IDENTIFIED}

- DOCUMENT AND REPORT PROBLEM TO NRC, STATE

- EVALUATE PROBLEM AND PROPOSE A SOLUTION

- DEVELOP CORRECTIVE ACTION PLAN AND NOTIFY NRC AND STATE

- SELECT CONTAACTOR TO PERFORM CORRECTIVE ACTION

- ESTABLISH CONTRACTUAL CONDITIONS FOR PERFORMING CORRECTIVE ACTION AND GUARANTEE CORRECTIVE ACTION WILL BE PERFORMED IN ACCORDANCE WITH CONTRACTUAL AQREEMENTS AND DESIQN SPECCIFICATIONS
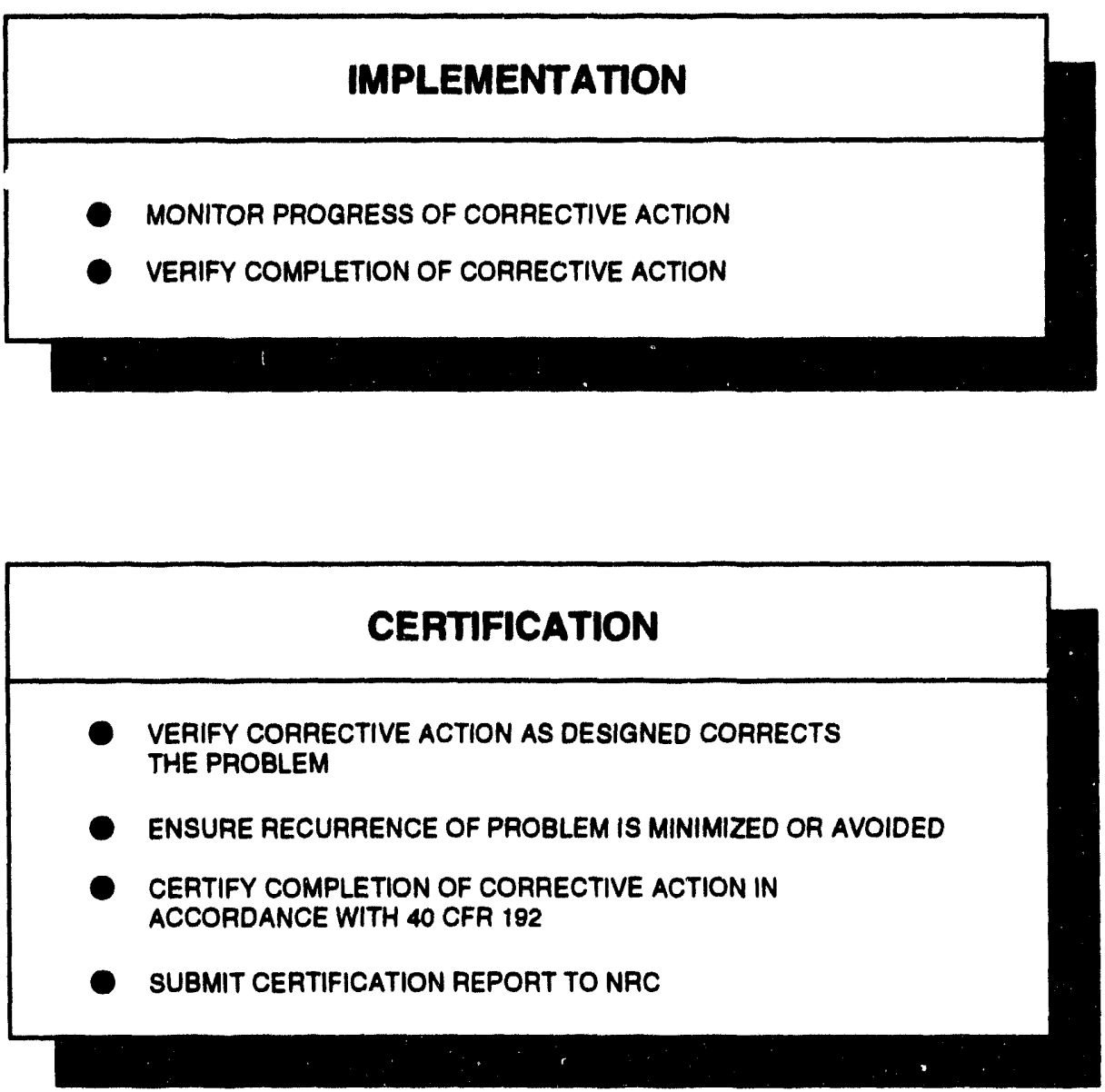

FIGURE 9.2

KEY ELEMENTS IN THE CORRECTIVE ACTION PROCESS 
action program begin within 18 months of confirmation of an exceedance at a disposal cell. Assessing the extent of a problem and developing a corrective action plan will not be considered initiation of the corrective action program. Section 9.0 of the UMTRA LTSP guidance document (DOE, 1992a) contains details on corrective action.

\subsection{PROBLEM IDENTIFICATION}

Site inspections by qualified inspectors and routine custodial maintenance are designed to identify problems at the developmental stage, thus eliminating the need for corrective action. However, extreme natural events, vandalism, or unanticipated events may require additional data or evaluative monitoring to assess whether uncorrected problems would threaten site integrity. An on-site inspection/preliminary assessment would include, but not be limited to, the following:

- Quantifying the nature and extent of the problem.

- Reevaluating germane engineering design parameters.

- Establishing a data collection and/or evaluative monitoring program to quantify the magnitude of th. problem.

\subsection{CERTIFICATION AND REPORTING PROCEDURES}

The DOE will prepare progress reports on each corrective action while it is under way or under evaluation. The NRC will receive a copy of each report, or the reports will be attached to the annual report. The NRC will be informed of all potential problems and solutions. All reports will also be provided to the state of Oregon.

After corrective action is complete, all work will be certified in accordance with EPA standards. The NRC will review this certification. A copy of the certification statement will become part of the permanent site files, as will all reports, data, and documentation generated during the corrective action. 


\subsection{RECORD KEEPING AND REPORTING REQUIREMENTS}

The DOE will maintain a permanent site file containing all information needed to prepare for and conduct site surveillance. Carefully compiled, complete, accurate reports of site-surveillance activities will be maintained in accordance with archival procedures set forth in 41 CFR 101 and 36 CFR 1220-1238 (Subchapter B - Records Management).

As required by 55 FR 45591 , the DOE will provide an annual report to the NRC documenting the results of the long-term surveillance program. Copies of the annual report will be provided to the state of Oregon and will be added to the Lakeview permanent site file. The annual reports and supporting documentation in the permanent site file will accomplish the following:

- Document the history of disposal site performance.

- Demonstrate to the NRC that licensing provisions were met.

- Provide the DOE and the NRC with information needed to forecast future sitesurveillance and monitoring needs.

- Inform the public that site integrity has been maintained.

\subsection{RECORDS}

The GJPO will maintain the Lakeview permanent site file in Grand Junction, Colorado. All original deeds, custody agreements, and other property documents will be kept at the DOE Facilities and Property Management Division, Albuquerque, New Mexico. Copies of these documents will also be maintained in GJPO files.

Surveillance and maintenance documentation will be maintained at the GJPO as a separate record collection from the UMTRA Project Document Control Center. As such, the records will be handled in accordance with DOE Order 1324.2A, Records Disposition, to ensure their proper handling, scheduling, and disposition.

All information will be available for NRC and public review. The Lakeview permanent site file will include the following:

- Licensing documentation.

- The site-specific LTSP.

- Disposal site legal description, title, custody documentation, and cooperative agreements.

- Interagency agreements, authorizations, and access agreements. 
- Documentation of rights of entry.

- EA and finding of no significant impact.

- Disposal site characterization report and processing site characterization report.

- Final RAP and final design for construction.

- Pertinent design and construction documents and drawings.

- Site certification report (certification summary, completion, and final audit reports).

- As-built drawings.

- Site atlas (vicinity, topographic, and base maps).

- Baseline and aerial photographs.

- Ground water monitoring reports and records.

- Additional monitoring reports and records.

- Monitor well permits and well abandonment records.

- Annual reports to the NRC.

- Annual inspection reports and records.

- Follow-up or contingency inspection preliminary assessments, reports, and records.

- Custodial maintenance or repair reports and records.

- Corrective action plans, reports, and records.

- QA program plan.

Attachment 3 lists documentation that will be transferred to the GJPO for the long-term surveillance program.

The GJPO will update the Lakeview permanent site file as necessary, after annual disposal site inspections are complete. Original UMTRA Project records and files will be archived with the DOE UMTRA Project Office, Albuquerque, New Mexico. Copies of the documentation and annual updates and additions will be kept in the permanent site file held by the GJPO, Grand Junction, Colorado. 


\subsection{REPORTS}

The GJPO will provide an annual report to the NRC, documenting the results of annual site inspections and any other activities conducted in conjunction with the long-term surveillance program. Criterion 12 to Appendix A of 10 CFR 40 stipulates that the annual report must be submitted no more than 90 days after the date of the last UMTRA Project site inspection for that calendar year.

The GJPO also will submit reports to the NRC documenting follow-up or contingency inspections and any corrective action plans. If any unusual damage or disruption is discovered, Criterion 12 requires that all preliminary inspection reports must be submitted within 60 days of the discovery.

The results of the ground water monitoring program will be reported annually to the NRC. The UMTRA Project Office will be responsible for preparing these ground water monitoring reports until this responsibility is transferred to the GJPO. 


\subsection{EMERGENCY NOTIFICATION AND REPORTING}

The Collins Ranch disposal cell was designed to comply with 40 CFR 192 with minimum maintenance and oversight for a period of 1000 years, or at least 200 years. However, unforeseen events could create problems that could affect the disposal cell's ability to remain in compliance with 40 CFR 192. Therefore, the DOE has requested notification from state and federal agencies of discoveries or reports of any purposeful intrusion or damage at the disposal site as well as the occurrence of earthquakes, tornados, or floods in the disposal site area.

\subsection{AGENCY AGREEMENTS}

The DOE has negotiated notification agreements with the Lake County Sheriff's Department (Lakeview, Oregon), the USGS National Earthquake Information Center (Denver, Colorado), and the Oregon Office of the National Weather Service. Copies of the agreements are presented in Attachment 7. The designated point of contact for emergency notification is the GJPO 24-hour phone line (303-248-6070). This number is posted on the Collins Ranch disposal site entrance sign so the public can notify the DOE, if problems are discovered.

In accordance with the agreements, the UMTRA Project Office will be the designated facility contact until the Collins Ranch disposal site is brought under general license. After that, the designated facility contact will be the GJPO.

Response letters from all of the agencies will be kept in the permanent site file.

Contact lists and telephone numbers for all agencies and parties with whom the DOE has entered into agreements will be updated annually, in conjunction with the site inspection, for inclusion in the disposal site inspection report.

To further solidify written agreements with these agencies, the DOE GJPO shall contact these agencies periodically to update them about the location of and concerns for the Collins Ranch disposal site.

\subsection{UNUSUAL OCCURRENCES}

The DOE has requested that the GJPO be notified of any unusual occurrences in the disposal site area that may affect surface or subsurface stability. The Lake County Sheriff's Department agreed to notify the GJPO if anything out of the ordinary (i.e., human intrusion, fire) is observed by the staff or reported to the office (Attachment 7).

\subsection{EARTHQUAKES}

The DOE subscribes to the USGS Early Warning Service for notification when an earthquake is of sufficient magnitude to threaten a disposal site. This service provides data on the magnitude of the event and the location of the epicenter. 
The USGS National Earthquake Information Center has agreed to notify the DOE GJPO if a seismic event occurs that fits any of the following descriptions (Attachment 7):

- Any earthquake of magnitude 3.0 or greater, within 0.3 degree (about $20 \mathrm{mi}$ [30 km]) of the site.

- Any earthquake of magnitude $\mathbf{5 . 0}$ or greater, within 1.0 degree (about $\mathbf{7 0}$ mi [110 km]) of the site.

\subsection{METEOROLOGICAL EVENTS}

The Oregon office of the National Weather Service in Medford, Oregon, has agreed to notify the GJPO within 8 hours of issuing a flash flood or tornado warning in Lake County, Oregon (Attachment 7). 


\subsection{QUALITY ASSURANCE}

The GJPO is responsible for developing QA procedures specific to the UMTRA Project long-term surveillance program. The GJPO Long-Term Surveillance Program Quality Assurance Program Plan (DOE, 1992f) specifies the following requirements:

- Program planning.

- Program activities, including inspections, site maintenance, corrective action, and emergency responses.

- Monitoring, if required.

- Personnel qualifications and training.

- Program surveillance and audits.

- Analytical QA.

- Analytical data validation.

All site inspections, monitoring data, records, photographs, maps, and other information related to the LTSP for the Collins Ranch disposal site are subject to formal and unannounced audits by the DOE UMTRA Project Office or the NRC. Specific QA criteria have already been developed for aerial photographs (DOE, 1992a).

\section{Ground water monitoring}

Ground water monitoring is required for compliance with 52 FR 36000 at the Collins Ranch disposal site. The ground water monitoring program will be conducted by the UMTRA Project Office until the site is licensed. Thereafter, site monitoring under the LTSP will be conducted by the GJPO. Prior to transferring a licensed disposal site to the GJPO, the UMTRA Project Office will ensure that the GJPO's QA/OC procedures for ground water monitoring (including sample collection, laboratory analysis, and data validation) are consistent with standard industry practices as implemented in applicable SOPs in the UMTRA TAC SOP manual (JEG, n.d.) and all applicable regulations.

QA activities for ground water monitoring will describe the policy, organization, functional activities, and QA/QC protocols needed to achieve the data quality objectives (DOO) of the intended use of the data. Specifically, QA activities will do the following:

- Identify the organizations involved with ground water monitoring activities and describe their operational, field, laboratory, and QA responsibilities.

- Summarize the DQOs for ground water restoration and the QA objectives for measuring data: precision, accuracy, representativeness, completeness, and comparability. 
- Discuss procedures for field and laboratory analysis of environmental samples and for sample custody, handling, packaging, shipping, and documentation. Laboratory analyses of environmental samples include the following:

- Inorganic, organic, and radiometric constituents.

- Other chemical, physical, and water-quality parameters.

- Discuss QA in field measurements. The QA procedures for field and laboratory methods appear in applicable SOPs in the UMTRA TAC SOP manual (JEG, n.d.). When an SOP has not been completed for an activity, best management practices (standard industry procedures) will be followed.

- Describe data validation, $Q A / O C$, and data reporting, calibration frequency, and preventive maintenance procedures for field and laboratory equipment.

- Establish guidance on internal QC checks and data reduction, validation, and reporting requirements for field and laboratory environmental samples.

- Present UMTRA Project system audit procedures and technical, field, and laboratory performance audit procedures.

- Suggest field and laboratory corrective action and procedures for corrective action resulting from audits.

- Present QA reporting procedures, outlining reporting requirements to management.

- Describe the record-keeping system. 


\subsection{PERSONNEL HEALTH AND SAFETY}

DOE Order 5480.1B, Environment, Safety and Health Program for DOE Operations, establishes personnel health and safety procedures for all DOE operations. After a disposal site is licensed and transferred to the GJPO, the GJPO is responsible for health and safety procedures for GJPO personnel and GJPO subcontractors. The GJPO will determine health and safety requirements for its personnel in accordance with applicable orders and federal regulations. The disposal cell was constructed to control Ra-226 and radon-222 releases from the residual radioactive material to within regulatory standards (52 FR 36000; 40 CFR 192.02(a)); therefore, radiation exposure tracking and dosimetry badges are not needed.

\subsection{HEALTH AND SAFETY}

The inspector's health and safety training and certifications, the locations and telephone numbers for emergency medical and law enforcement facilities, and the facility contact 24-hour telephone number will be verified before each site inspection.

Spacific safety concerns at the Collins Ranch disposal site include slip, trip, and fall hazards; animal, snake, and insect bites; heat and cold stress; fire hazards; puncture and cut hazards; and driving hazards.

\section{Emergency medical and law enforcement}

Local emergency medical and law enforcement agencies were briefed on the scope of work at the site during the long-term surveillance and maintenance phase. The following 24-hour emergency numbers are pertinent:

- Fire: 911

- Ambulance: 911

- Police/sheriff: (503) 947-2504/947-6027 or 911.

The nearest hospital with an emergency room is located in Lakeview, Oregon, $7 \mathrm{mi}(11 \mathrm{~km})$ south of the disposal site. Lake District Hospital is located at 700 South J Street, Lakeview, Oregon. Directions to the hospital from the site are as follows:

From Highway 395 South, drive through town and turn right on 7th South J Street. The hospital is located at the end of the road.

Because the nearest telephone is several miles from the site and may not be accessible, a mobile phone should be taken on site visits. 


\subsection{REPORTABLE INCIDENTS}

The inspection team should be briefed by the GJPO health and safety officer on potential site hazards and other requirements before site inspections or visits.

In accordance with DOE Order 5000.3B, Occurrence Reporting and Processing of Operations Information, any accident, injury, or environmental event (e.9., tornado, flood) occurring during the site inspection is a reportable incident. The condition or event must be reported to the GJPO facility manager or designated contact within 8 hours of occurrence. The GJPO facility manager's 24-hour telephone number for reporting an incident is (303) 248-6070. 


\subsection{LIST OF CONTRIBUTORS}

The following individuals contributed to the preparation of this LTSP.

\begin{tabular}{ll}
\hline Name & Contribution \\
\hline M. B. Leaf (TAC) & Site Manager, document review \\
C. Silva (TAC) & Document coordination \\
K. Monks (TAC) & Hydrology \\
P. Martinez (TAC) & Real estate \\
E. Artiglia, L. Ulland, A. Holm (TAC) & Document review \\
J. Lommler (TAC) & Engineering, document review \\
J. Crain (TAC) & Engineering review \\
J. Torline (TAC) & Technical editing, document production \\
& coordination \\
L. Sanchez & Word processing \\
E. Bond, B. Harvey (TAC) & Graphic design \\
\hline
\end{tabular}


15.0 REFERENCES

ASP (American Society of Photogrammetry). 1980. Manual of Photogrammetry, fourth edition, American Society of Photogrammetry, Falls Church, Virginia.

Bouwer, H., 1978. Ground Water Hydrology, McGraw.Hill, New York, New York.

Burt, C., and S. Cox, 1993. An Assessment of Plant Biointrusion on Six UMTRA Project Disposal Cells, Radioactive Waste Management and Environmental Restoration Technology and Programs, Waste Management 1993 Conference Proceedings, Tucson, Arizona.

Corning, M., 1992. Soil scientist, U.S. Soil Conservation Service, Lakeview, Oregon, personal communication with Charles J. Burt, Environmental Services, Jacobs Engineering Group Inc., Albuquerque, New Mexico, July 30, 1992.

Corning, M., 1991. Soil scientist, U.S. Soil Conservation Service, Lakeview, Oregon, personal communication with Charles J. Burt, Environmental Services, Jacobs Engineering Group Inc., Albuquerque, New Mexico, June 12, 1991.

DOE (U.S. Department of Energy), 1993. Licensing Plan for UMTRA Project Disposal Sites, final, September 1993, DOE/AL/62350-9F, DOE UMTRA Project Office, Albuquerque Operations Office, Albuquerque, New Mexico.

DOE (U.S. Department of Energy), 1992a. Guidance for Implementing the UMTRA Project Long-term Surveillance Program, final, September 1992, UMTRA-DOE/AL350125.0000, DOE UMTRA Project Office, Albuquerque Operations Office, Albuquerque, New Mexico.

DOE (U.S. Department of Energy), 1992b. Remedial Action Plan and Site Conceptual Design for Stabilization of the Inactive Uranium Mill Tailings Site at Lakeview, Oregon, UMTRA-DOE/AL-050510.0000, DOE UMTRA Project Office, Albuquerque Operations Office, Albuquerque, New Mexico.

DOE (U.S. Department of Energy), 1992c. 1991 Annual Prelicensing Inspection of the Lakeview, Oregon, UMTRA Project Disposal Site, DOE/ID/12584-106, prepared by the U.S. Department of Energy, UMTRA Project Office, Albuquerque Operations Office, Albuquerque, New Mexico.

DOE (U.S. Department of Energy). 1992d. Software Program for Environmental Analysis and Reporting (SPEAR) System, U.S. Department of Energy, UMTRA Project Office, Albuquerque Operations Office, Albuquerque, New Mexico.

DOE (U.S. Department of Energy), 1992e. Vegetation Growth Patterns on Six RockCovered UMTRA Project Disposal Cells, UMTRA-DOE/AL-400677.0000, DOE UMTRA Project Office, Albuquerque Operations Office, Albuquerque, New Mexico. 
DOE (U.S. Department of Energy), 1992f. Long-Term Surveillance and Maintenance Program Quality Assurance Program Plan, P-GJFO-152, July 1992, prepared for the U.S. Department of Energy by Chem Nuclear Geotech, Inc., DOE Grand Junction Projects Office, Grand Junction, Colorado.

DOE (U.S. Department of Energy), 1985a. Environmental Assessment of Remedial Action at the Lakeview Uranium Mill Tailings Site, DOE/EA-0271, DOE UMTRA Project Office, Albuquerque Operations Office, Albuquerque, New Mexico.

DOE (U.S. Department of Energy), 1985b. Disposal Site Characterization Report for the Alternate Uranium Mill Tailings Disposal Site at Collins Ranch Near Lakeview, Oregon, UMTRA-DOE/AL-050523.0001, DOE UMTRA Project Office, Albuquerque Operations Office, Albuquerque, New Mexico.

EPA (U.S. Environmental Protection Agency), 1989a. Guidance for Conducting Remedial Investigations and Feasibility Studies Under CERCLA - Interim Final Guidance, EPA/530-SW-89-026, EPA Office of Solid Waste, Waste Management Division, Washington, D.C.

EPA (U.S. Enviru. "nental Protection Agency), 1989b. Statistical Analysis of Ground Water Monitoring Data at RCRA Facilities - Interim Final Guidance, EPA/530-SW-89026, EPA Office of Solid Waste, Waste Management Division, Washington, D.C.

EPA (U.S. Environmental Protection Agency), 1988. Guidance on Remedial Actions for Contaminated Ground Water at Superfund Sites, EPA/540/G-88-003, OSWER Directive 9283.1-2.

EPA (U.S. Environmental Protection Agency), 1986. RCRA Ground Water Monitoring Technical Enforcement Guidance Document, OSWER Directive 9950.1.

FBD (Ford Bacon, and Davis Utah, Inc.), 1977. "Fhase II-Title I Engineering Assessment of Inactive Uranium Mill Tailings Lakeview Site, Lakeview, Oregon," GJT-18, U.S. Department of Energy, Grand Junction, Colorado.

JEG (Jacobs Engineering Group Inc.), n.d. Albuquerque Operations Manual, standard operating procedures, prepared by Jacobs Engineering Group, Albuquerque, New Mexico, for the U.S. Department of Energy, UMTRA Project Office, Albuquerque Operations Office, Albuquerque, New Mexico.

MKF (MK-Ferguson), 1991. Lakeview, Oregon, Final Completion Report, prepared by MKF for the U.S. Department of Energy, UMTRA Project Office, Contract No. DE-AC04-83AL18796, Albuquerque Operations Office, Albuquerque, New Mexico. 
TAC (Technical Assistance Contractor), 1993. "Unpublished field notes, Lakeview, Oregon, uranium mill tailings disposal site," unpublished report prepared by the TAC (Jacobs-Weston Team), Albuquerque, New Mexico, for the U.S. Department of Energy, UMTRA Project Office, Albuquerque Operations Office, Albuquerque, New Mexico.

TAC (Technical Assistance Contractor), 1992. "Unpublished field notes, Lakeview, Oregon, uranium mill tailings disposal site," unpublished report prepared by the TAC (Jacobs-Weston Team), for the U.S. Department of Energy, UMTRA Project Office, Albuquerque, New Mexico.

Temple et al. (D. M. Temple, K. M. Robinson, R. M. Ahring, and A. G. Davis), 1987. Stability Design of Grass-Lined Open Channels, U.S. Department of Agriculture, Agriculture Handbook Number 667, U.S. Government Printing Office, Washington, D.C.

\section{DOE ORDERS}

Order 1324.2A, Records Disposition, September 13, 1988, Office of Information Resources Management, U.S. Department of Energy, Washington, D.C.

Order 5000.3B, Occurrence Reporting and Processing of Operations Information, February 22, 1993, U.S. Department of Energy, Washington, D.C.

Order 5400.1, General Environmental Protection Program, June 29, 1990, U.S. Department of Energy, Environmental Protection Division, Office of Environment, Safety and Health, Washington, D.C.

Order 5480.1B, Environment, Safety and Health (ES\&H) Program for DOE Operations, September 1986, U.S. Department of Energy, Safety Programs Division, Washington, D.C.

Order 5700.6C, Quality Assurance, August 21, 1991, Office of Nuclear Energy and Office of Environment, Safety, and Health, U.S. Department of Energy, Washington, D.C.

\section{FEDERAL REGISTER}

52 FR 36000, "Standards for Remedial Actions at Inactive Uranium Processing Sites; Proposed Rule," September 24, 1987, Federal Register, Office of the Federal Register, National Archives and Records Administration, Washington, D.C.

55 FR 45591, "Custody and Long-Teim Care of Uranium and Thorium Mill Tailings Disposal Sites," October 30, 1990, Federal Register, U.S. Nuclear Regulatory Commission, Office of the Federal Register, National Archives and Records Administration, Washington, D.C. 


\section{U.S. CODE}

42 USC $\$ 7901$, Public Law 95-604, Uranium Mill Tailings Radiation Control Act of 1978, November 8, 1978, 95th Congress of the United States of America, Washington, D.C.

\section{U.S. CODE OF FEDERAL REGULATIONS}

10 CFR 40, "Domestic Licensing of Source Material," Title 10, Code of Federal Regulations, Part 40, U.S. Nuclear Regulatory Commission, Office of the Federal Register, National Archives and Records Administration, Washington, D.C.

36 CFR 1220-1238, "National Archives and Records," Subchapter B - Records Management, National Archives and Records Administration, Office of the Federal Register, National Archives and Records Administration, Washington, D.C.

40 CFR 192, "Health and Environmental Protection Standards for Uranium and Thorium Mill Tailings," Title 40, Code of Federal Regulations, Part 192, U.S.

Environmental Protection Agency, Office of the Federal Register, National Archives and Records Administration, Washington, D.C.

41 CFR 101, "Federal Property Management Regulations," Title 41, Code of Federal Regulations, Part 101, General Services Administration, Office of the Federal Register, National Archives and Records Administration, Washington, D.C. 
ATTACHMENT 1

SITE OWNERSHIP/CUSTODY DOCUMENTATION 


\section{ATTACHMENT 1}

\section{SITE OWNERSHIP/CUSTODY DOCUMENTATION}

\section{GENERAL}

The Collins Ranch disposal site near Lakeview, Oregon, was acquired by the state of Oregon through a civil action suit, Lake County Circuit Case No. L-86-060-CV, File No. 330-050-TL001-86, state of Oregon, by and through the Energy Facility Siting Counsel $v$ John Collins, et al. Final disposition of the case provided a 40-acre (16-ha) disposal site in fee with perpetual access leading west from County Road (CR) 2-16B across the Collins Ranch to the disposal area, as well as unlimited access to all off-site ground water monitoring wells.

\section{DOCUMENTATION OF ACQUISITION}

\section{A. Legal description}

The Collins Ranch disposal site is located on a 40-acre (16-ha) parcel of land in Sections 11 and 12, T38S, R19E, Willamette Meridian, Lake County, Oregon, and is more particularly described in the following paragraph.

Beginning at a point on the East line of Section 11, T38S, R19E, said point of beginning bears $\mathrm{N} 00^{\circ} 17^{\prime} 25^{\prime \prime} \mathrm{E}, 816.36$ feet $(\mathrm{ft}$ ) from the southeast corner of Section 11; thence West - $211.02 \mathrm{ft}$; thence North $1950.00 \mathrm{ft}$; thence East 220.90 $\mathrm{ft}$ to the East line of Section 11, T38S, R19E; thence continuing in Section 12, T38S, R19E, East $779.10 \mathrm{ft}$; thence South $1000.00 \mathrm{ft}$; thence South $24^{\circ} 42^{\prime} 18^{\prime \prime}$ West $1045.71 \mathrm{ft}$; thence West $351.93 \mathrm{ft}$ to the point of beginning. Parcel contains 40.00 acres.

B. Legal description of access road to disposal area

A 60-foot strip of land for easement purposes located in Section 12, Township 38 South, Range 19 East, Willamette Meridian, Lake County, Oregon, the centerline of which is more particulary described as follows:

Beginning at a point on the west right-of-way line of County Road 2-16B, said point of beginning bears North $00^{\circ} 10^{\prime} 19^{\prime \prime}$ East-30.00 feet; thence North $89^{\circ} 37^{\prime} 12^{\prime \prime}$ West -30.00 feet from the southeast section corner of Section 12; thence North $89^{\circ} 37^{\prime} 34^{\prime \prime}$ West-2638.25 feet to a point that bears North $00^{\circ} 22^{\prime} 26^{\prime \prime}$ East-30.00 feet from the south $1 / 4$ corner of Section 12; thence North $89^{\circ} 3^{\prime} 06^{\prime \prime}$ West-1449.65 feet; thence North $86^{\circ} 29^{\prime} 18^{\prime \prime}$ West-379.15 feet; thence along a 250.00 foot radius curve to the right 330.71 feet; thence North $10^{\circ} 41^{\prime} 45^{\prime \prime}$ West-359.83 feet; thence North $3^{\circ} 20^{\prime} 24^{\prime \prime}$ West-380.92 feet; thence North $00^{\circ} 45^{\prime} 38^{\prime \prime}$ East-55.72 feet; thence North $8^{\circ} 40^{\prime \prime} 28^{\prime \prime}$ East-40.01 feet; thence North $18^{\circ} 16^{\prime} 10^{\prime \prime}$ East 82.69 feet; thence North $11^{\circ} 18^{\prime} 58^{\prime \prime}$ East-41.38 feet; thence North $1^{\circ} 03^{\prime} 53^{\prime \prime}$ West-24.99 feet to the east boundary of the Collins Ranch disposal area, said point bears North $23^{\circ} 57^{\prime} 25^{\prime \prime}$ East-1356.57 feet from the southwest corner of Section 12. 
The basis of bearings for this description is the Oregon state plane coordinate system south zone.

\section{Recorded}

Filed: Book $\stackrel{*}{\text { Lake County, Oregon }}$ (date *)
(dage

"The U.S. Army Corps of Engineers (USACE) has been tasked to work in conjunction with the state of Oregon on transfer of the disposal site parcel to the Federal Government. This transfer is coupled with NRC concurrence that remedial action is complete. At that time, the transfer document will be signed and recorded, thus completing the real estate requirements for the licensing process.

Real estate correspondence and related documents are maintained and filed by the Property Management Branch, Facilities and Property Management Division, Albuquerque Operations Office, (505) 845-6450. Copies of all documents will also be maintained in the permanent Lakeview (Collins Ranch) site file at the Grand Junction Projects Office located in Grand Junction, Colorado. 
ATTACHMENT 2

NRC CONCURRENCE AND LICENSING DOCUMENTATION 


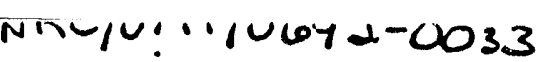

NUCLEAR REGULATORY COMMISSION

REGION IV

URANIUM RECOVERY FIELD OFFICE BOX 20025

DENVER, COLORADO 20000

JUN 151992

Docket No. WM-64

Albert Chernoff, Project Manager

U.S. Department of Energy

Aibuquerque Operations Office

P.0. Box 5400

Albuquerque, New Mexico 87115

Dear Mr. Chernoff:

In a letter dated May 7, 1992, you requested my concurrence and signature on three original signature pages for the Lakeview, Oregon, Remedial Action Plan.

For your information, we previously provided conditional concurrence in the form of a signed signature page in a letter to DOE dated June 9, 1986.

However, since there have been many changes to the Lakeview Remedial Action Plan since we initially provided that conditional concurrence, I have signed the three new signature pages as you requested in your May 7, 1992, letter.

Please note that the signature pages have been annotated to indicate that concurrence is conditional as DOE has elected to defer ground-water cleanup until after EPA promulgates its final ground-water protection standards.

If you have any questions, please contact me at (303) 231-5800 or the project manager, Ray Gonzales, at (303) 231-5808.

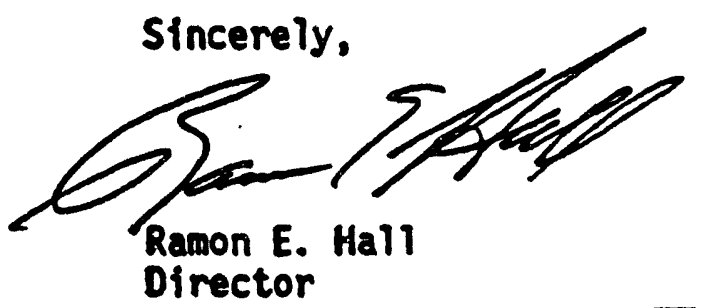

Attachment:

Signature pages

cc:

S. Hamp, DOE

P. Mann, DOE

F. Miera, Oregon

D. Stewart-Smith, Oregon

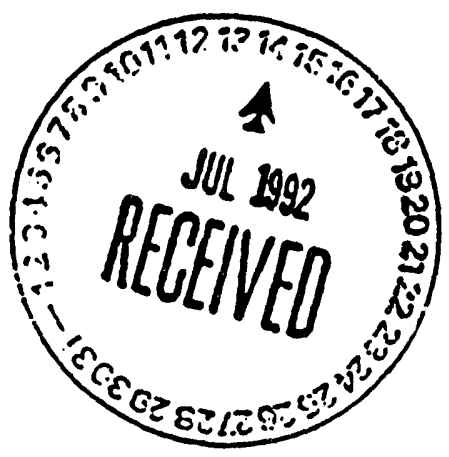




\section{U.S. DEPARTMEAT OF ENERGY CBRIIFICATION SUMARY for the \\ Iakeview, Oregan, Disposal Site}

The Uranium Mill Tailings Remedial Action Project Manager and the Contracting Officer for the U.S. Department of Energy certify that the Iakeview, Oregon, remedial action is complete. The processing and disposal sites have been remediated and meet all design criteria and technical specifications contained in the approved Remedial Action Plan, as required under Public Iaw 95-604. This certification applies only to the earth surface remediation. The groundwater restoration activities at the Iakeview mill site will be completed separately. The undersigned request that the U.S. Nuclear Regulatory Comission conarr in this certification.

Thelanif Thomas

Melanie J. Thomas

Contracting officer

Programs and RSD Branch

Contracts and Proarrentant Division

DATE: Qpeil/, /9q2
All Olle

Project Manager

Uranium Mill Tailings Remedial Action Project office

DATE: $\quad 31,9 / 92$

The Director, Uranium Recovery Field office, Region IV, U.S. Nuclear Regulatory Comission hereby conars with the U.S. Department of Energy's completion of surface remedial action at the Lakeview, Oregon processing and disposal site.

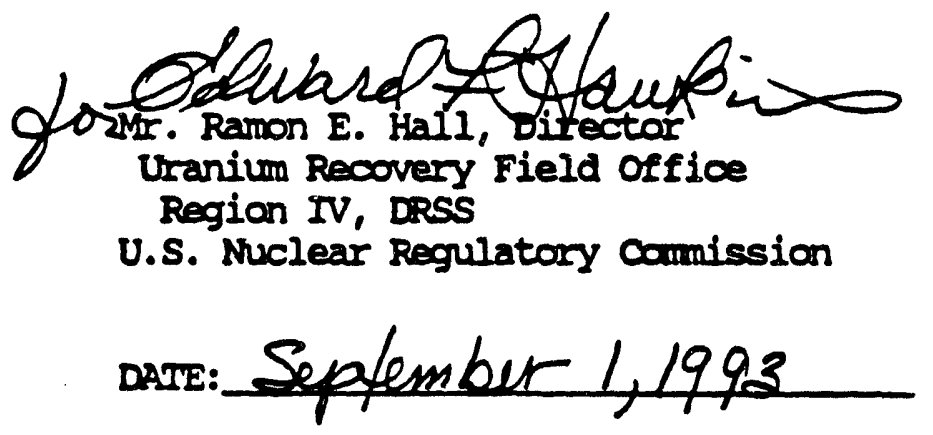




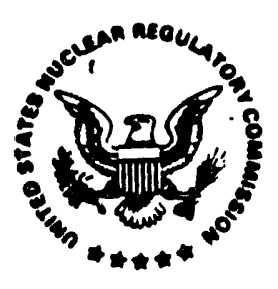

Docket No. WM-64
NRCJUMT/0993-0044

UNITED STATES

NUCLEAR REGULATORY COMMISSION

AEoION $N$

UAANIUM NECOVERY FELD OFFICE

Dox $20 \times 05$

DENVER, COLORADO

SEP 011993

U.S. Department of Energy

Aibuquerque Operations Office

ATTN: Albert R. Chernoff

P.0. Box 5400

Project Manager

Aibuquerque, New Mexico 87115

Dear Mr. Chernoff:

We have completed our review of the certification data for the uranium mill tailings site at Lakeview, Oregon. The data reviewed were the Final Completion Report, the Final Audit Report, and all other associated documentation pertinent to the completed remedial action at Lakeview. The results of our review are documented in the enclosed Final Completion Review Report.

Based on our review of the certification data and on observations and record checks made during periodic site visits, we concur that, with the exception of ground-water restoration, the Department of Energy (DOE) has completed the remedial action in accordance with the approved plans and specifications, and that this action complies with the Environmental Protection Agency's standards in 40 CFR 192, Subparts A-C. I have therefore signed the enclosed signature pages signifying NRC's concurrence in the completion of remedial action at Lakeview, Oregon.

Ground-water cleanup at the processing site will be addressed by DOE as part of a separate ground-water restoration program once the proposed EPA ground-water standards have been finalized. This will require that DOE maintain control of the processing site in a manner consistent with DOE's April 9, 1993, policy letter.

If you have any questions, please contact the NRC Lakeview project manager, Ray Gonzales, at FTS (303) 231-5808.

Sincerely,

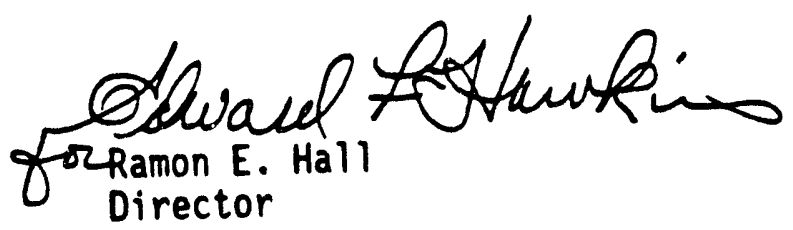

Enclosures:

As stated 
cc:

S. Hamp, DOE

F. Miera, Oregon

D. Stewart-Smith, Oregon 
U.S. Department of Energy

Agreement NO. OE -FCO4-84AL2OS34

Appendix $B$

SIGNATURE PAGE

THE UNITED STATES OF AMERICA DEPARTMENT OF ENERGY

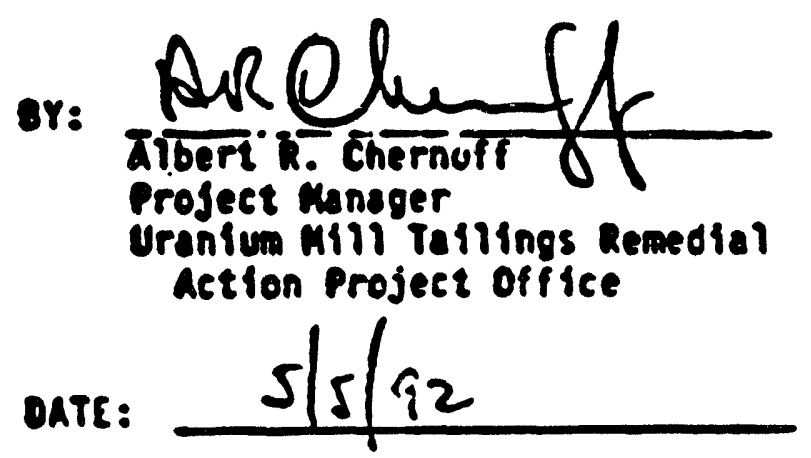

THE STATE OF OREGON

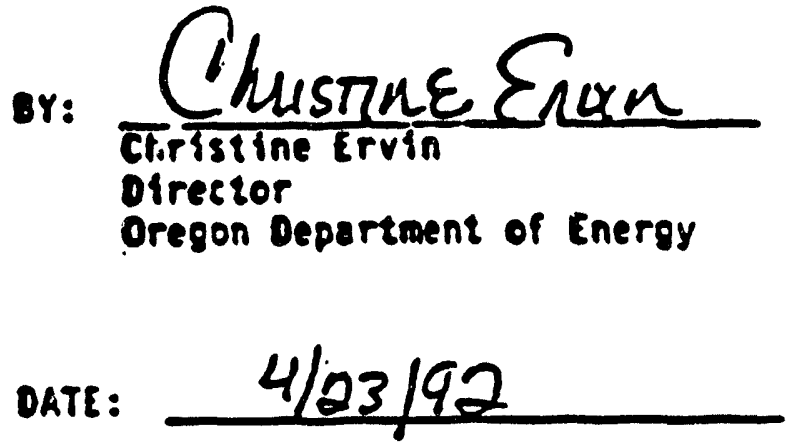

CONCURRENCE

THE UNITED STATES

NUCLEAR REGULATORY COMMISSION

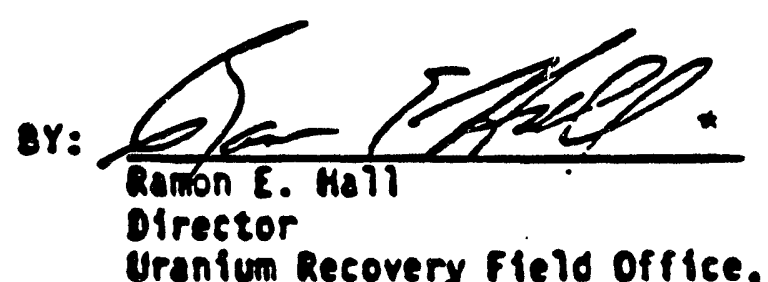

Uranium Recovery field office.

Region IV

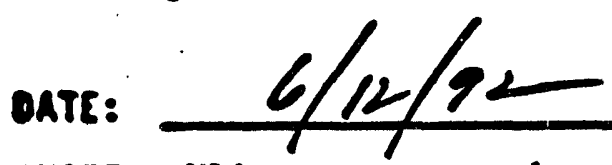

HOTE: NRC concurrence is conditional until 11 DOE adequately addresses groundwater cleanup in accordance with EPA standards. 
ATTACHMENT 3

LAKEVIEW PERMANENT SITE FILE INDEX 


\section{LAKEVIEW (COLLINS RANCH) PERMANENT SITE FILE INDEX}

\section{LICENSINO DOCUMENTATION}
A. Long-term Surveillance Plan (LTSP) (final)
B. Prelicensing Custodial Care
C. U.S. Nuclear Regulatory Commission Acceptance of LTSP
D. General License Takes Effect

\section{DOCUMENTATION OF DOE TITLE/CUSTODY}

A. Documentation:

- State

- Federal

- Tribal

B. Legal Description

C. Custodial Care Agreements

NATIONAL ENVIRONMENTAL POLICY ACT (NEPA) DOCUMENTATION
A. Environmental Impact Statement/Environmental Assessment
B. Record of Decision/Finding of No Significant Impact
C. Additional NEPA
D. Mitigation Action Plan

\section{REMEDIAL ACTION DOCUMENTATION}
A. Disposal Site Characterization Report
B. Remedial Action Plan/Remedial Action Selection Report
- Concurrence Pages (signed)
C. Draft/Final Technical Evaluation Report
D. Final Design for Construction
E. Additional Design/Construction Documents/Drawings
F. Final close-out Inspection Report 


\section{G. Site Certification Report/Package}

- U.S. Department of Energy Certification/Summary

- Final Completion Report

- Final Audit Report

- Completion Report Review

- Certification Pages (signed)

\section{AS-BUILT CONSTRUCTION}

\section{- Drawings and maps}

\section{PHOTOGRAPHS}
A. Construction Photographs
B. Aerial Photographs
C. Close-out/Inspection Photographs
D. Verification and Orientation/Initial Pre-licensing Inspection Photographs

\section{MONITORING DOCUMENTATION}
A. Active monitoring wells
B. Location of inactive (abandoned) monitor wells
C. Monitoring Station Records
D. Monitoring Reports
E. Programmatic Procedures

\section{AGREEMENTS}
A. Interagency
B. Individual/Private
UPDCC SITE FILE INDEX 

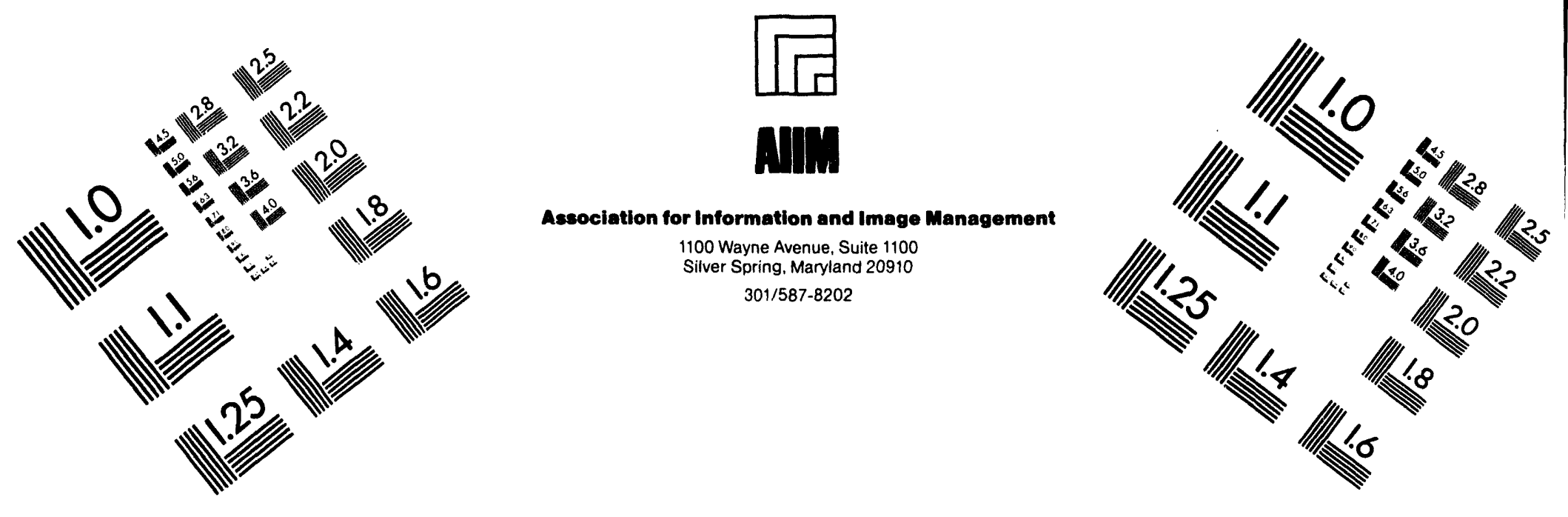

\section{Centimeter}

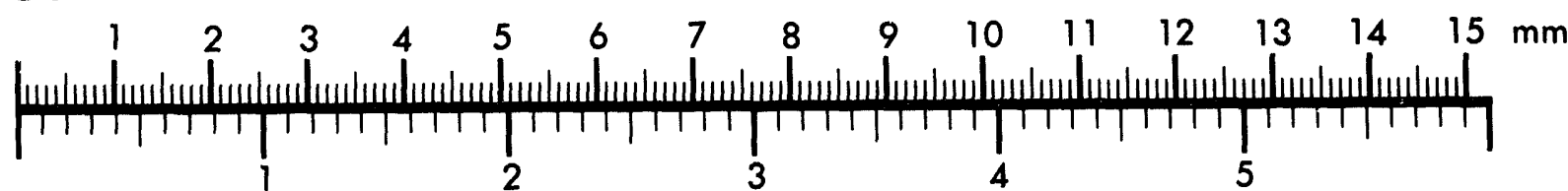
Inches
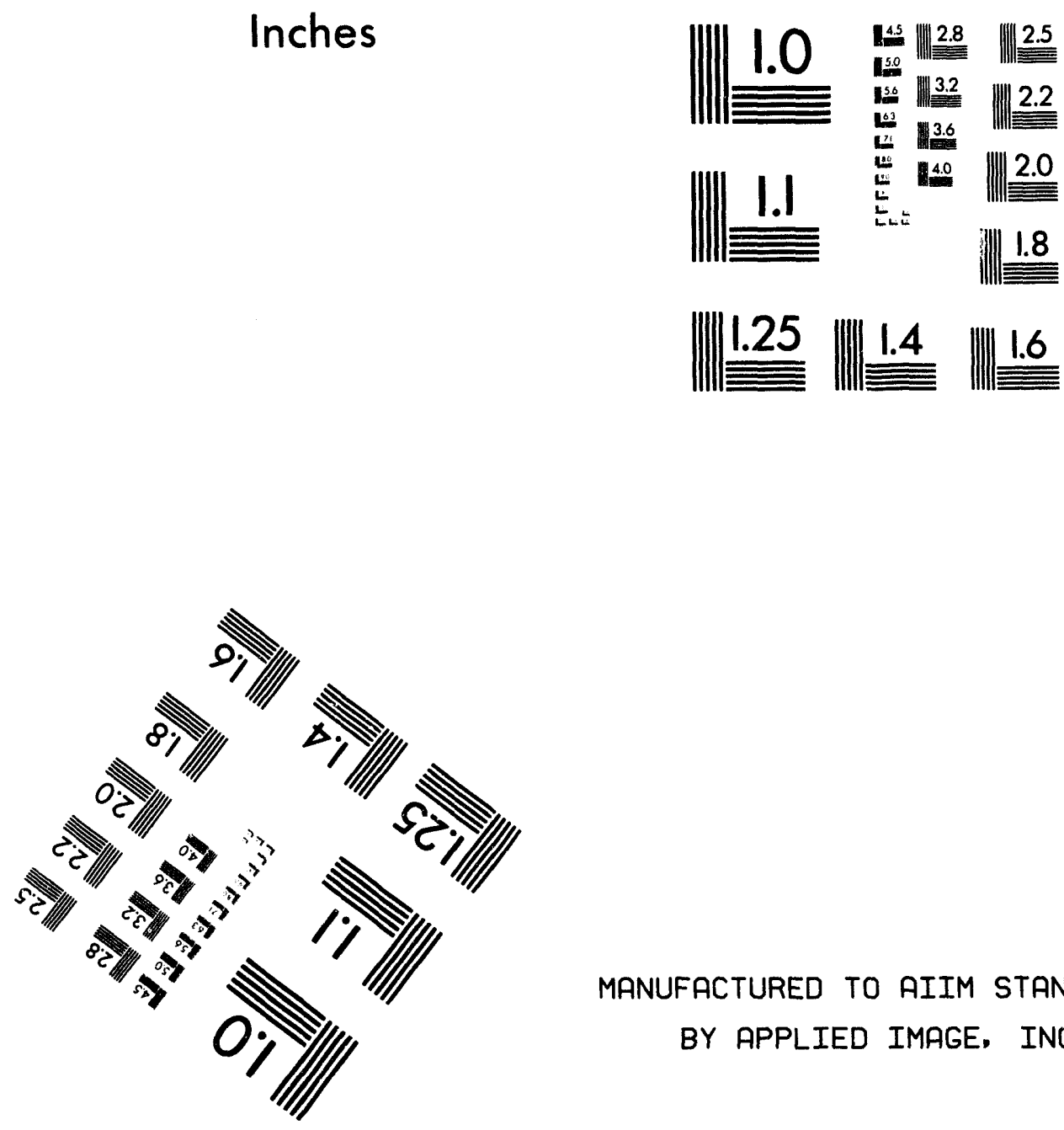

MANUFACTURED TO AIIM STANDARDS BY APPLIED IMAGE, INC.

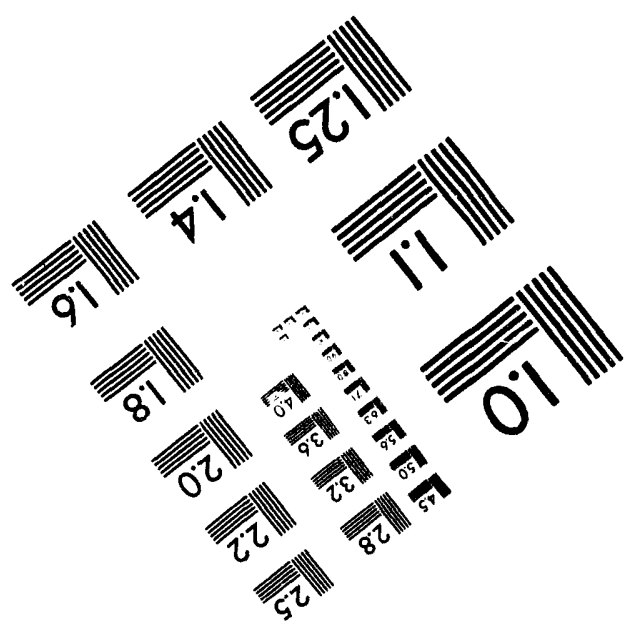



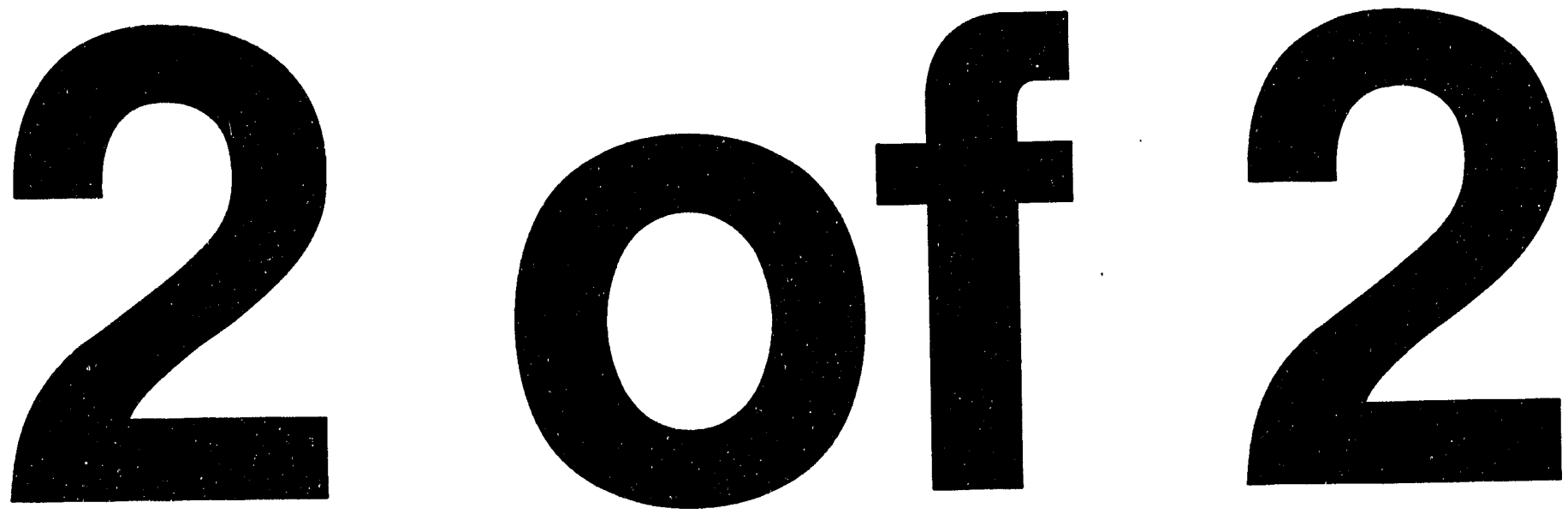
ATTACHMENT 4

SITE INSPECTION PHOTO LOG 


\section{SITE INSPECTION PHOTO LOG}

Site:

Site Activity:

Date: Time of Day: From to

Weather Conditions:

Roll Number: Film Type: Number of Exposures

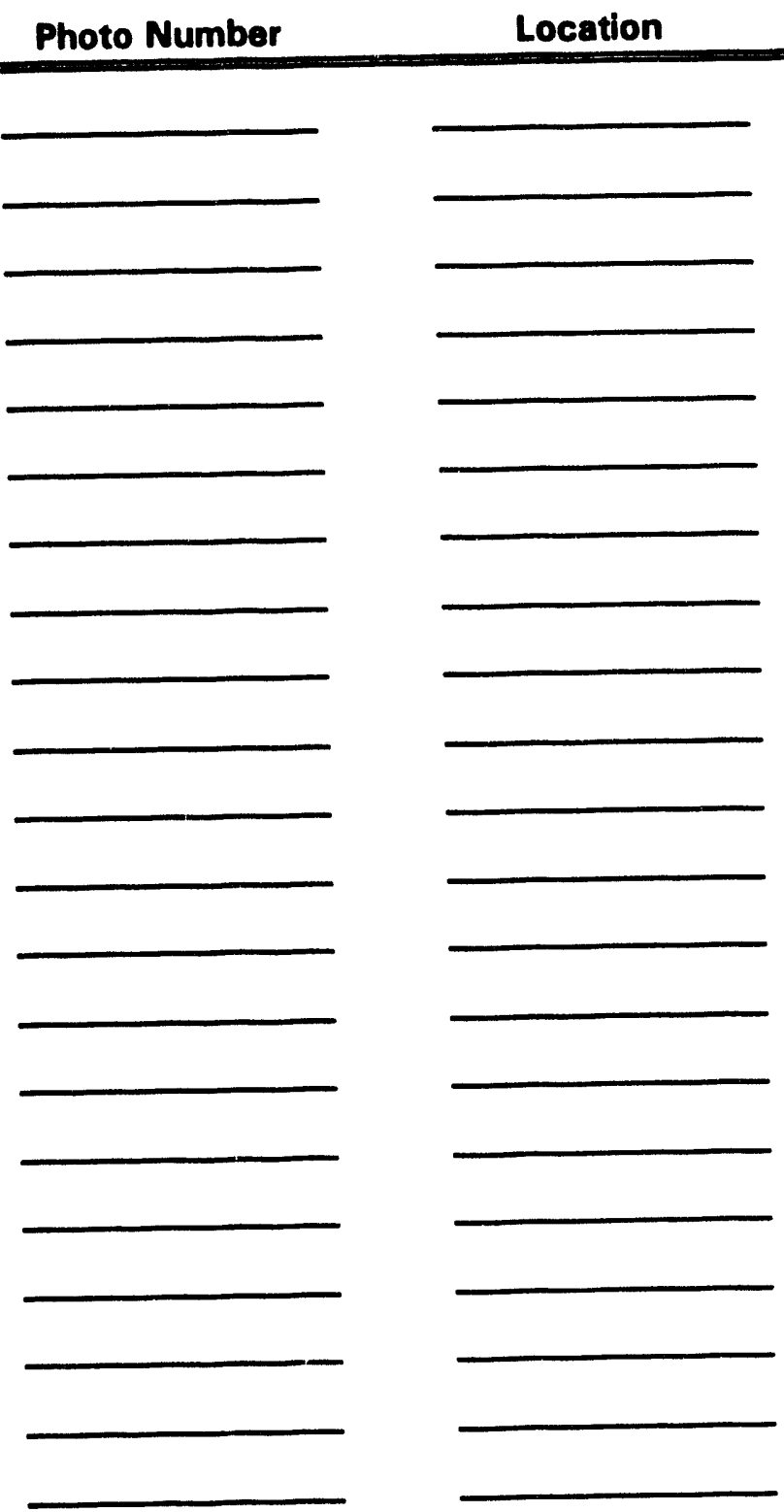




\section{SITE INSPECTION PHOTO LOG (CONT.)}

Site

Date

\section{Photo Number

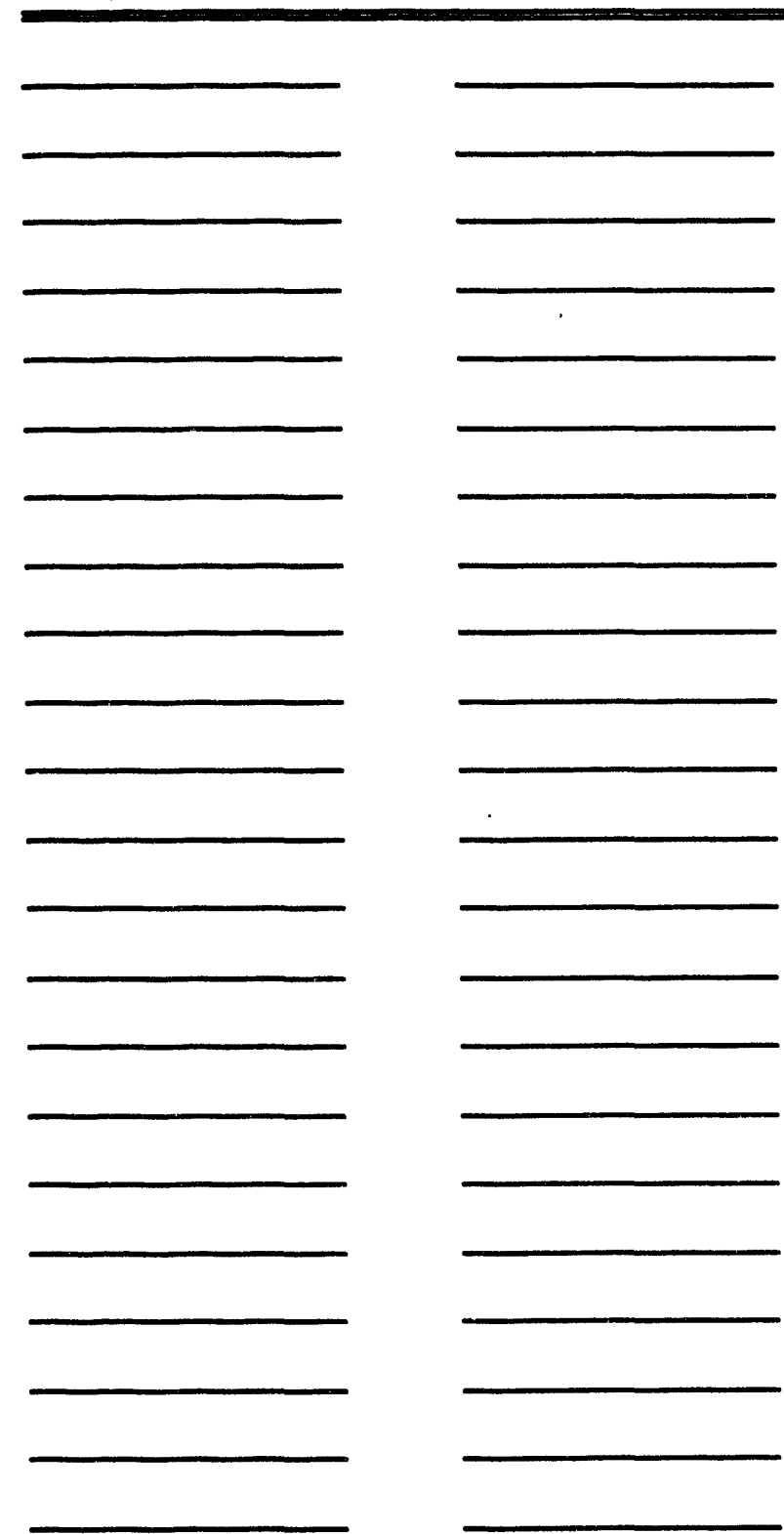

Photographer:

Printed Name

\section{Signature}




\section{SITE INSPECTION PHOTO LOG (CONT.)}

\section{Site}

Date

\section{Photo Number}

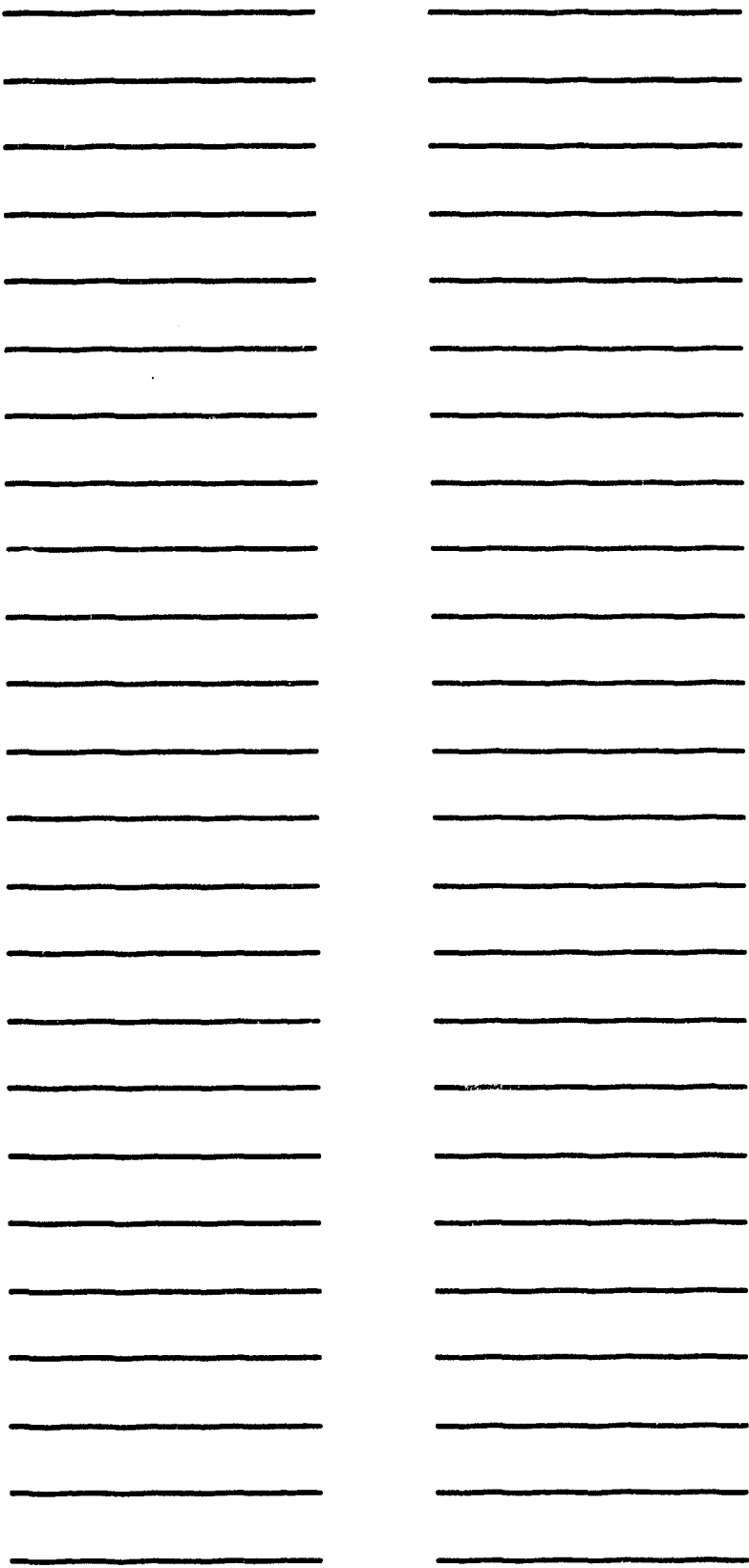




\section{SITE INSPECTION PHOTO LOG (CONT.)}

Photo Number

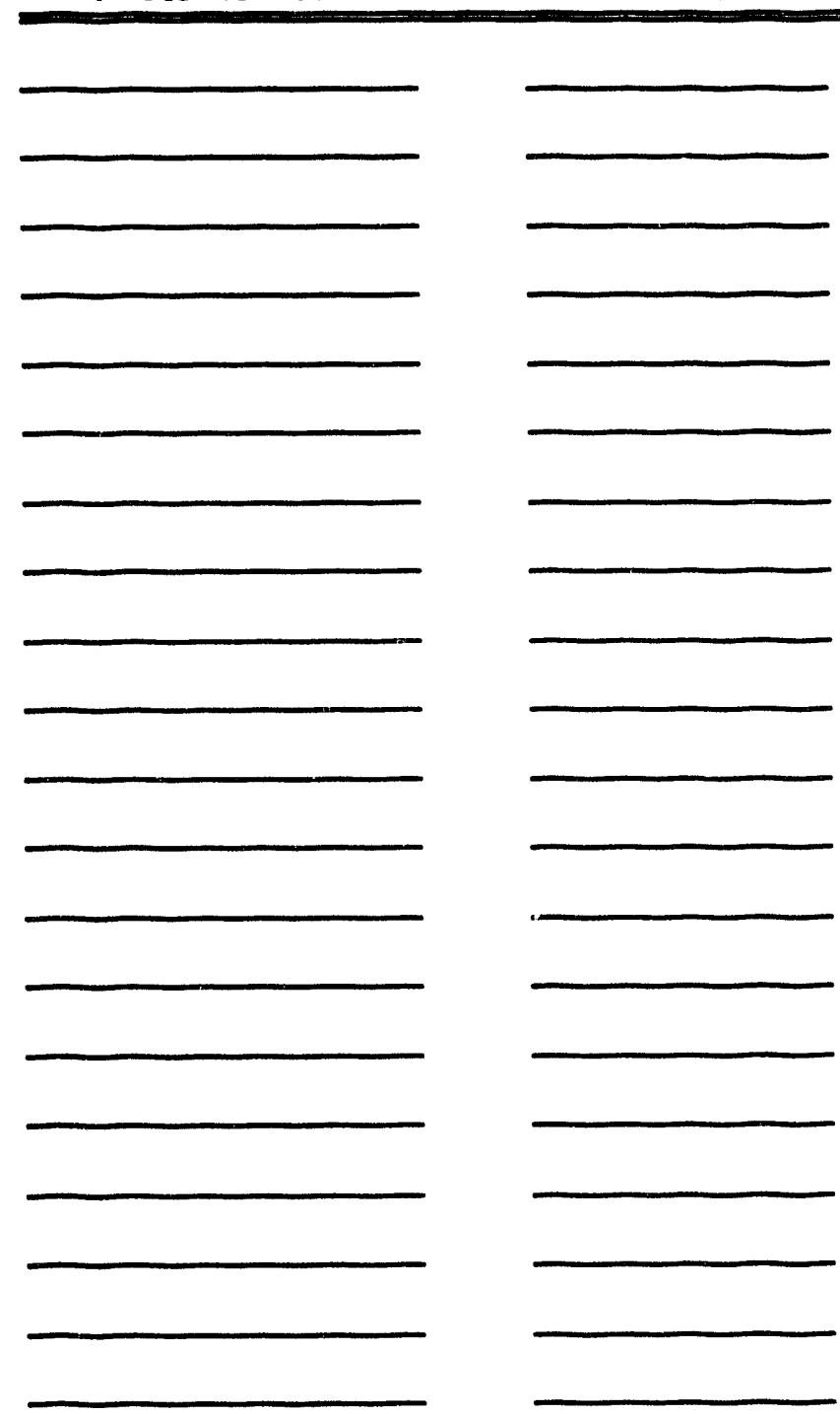

Description

Photographer: 
ATTACHMENT 5

SUPPORTING DOCUMENTATION 
UMTRA PROJECT STANDARD OPERATING PROCEDURES

\section{Section and}

SOP Number

16.1.1

16.1 .2

16.1 .3

16.1 .4

16.1 .5

16.1 .6

16.1 .7

16.1 .8

16.1 .9

16.1 .10

16.1 .11

16.1 .12

16.1 .13

16.1 .14

16.1 .15

16.1 .16

16.1 .17

16.1.18

16.1 .19

16.1 .20

16.1.21

16.1.22

16.2.1

16.2.2

16.2 .3

16.2 .4

16.2 .5

16.2.6

16.2 .7

16.2 .8

16.3.1
Title

Monitor Well Installation

Well Development

Slug Testing

Packer Testing

Aquifer Pump Testing

Soil-Water Sampler Installation and Sample Collection

Installation and Servicing of Tensiometers

Batch and Column Testing

Gravimetric Moisture Content of Drill Bit Cuttings

Field Measurements for TEMP, COND, pH, ALK, and TTL Acid

Sample Collection for Organic Substances

Measuring Sub-surface Content Using Neutron Moist. Meter

Field Determination of OX/Reduction Potential (ORP)

Field Determination of Dissolved Oxygen in Water Samples

Neutron Probe Access Hole Closure

Alternate Method for Determination of Dissolved Oxygen

Well Decommissioning Procedure

Assessment of Inherited Ground Water Wells for UMTRA Site

Permitting Procedures for Installation of Monitoring Wells

Well Repair Procedures

Measurement of Water Turbidity

Controlled Disposal of Potentially Contaminated Materials

Sample Collection, Preservation, and Ship of Water Samples

Water Sampling for Tritium Analysis

Evaluation of Chemical Analysis of Water Samples

Sampling Radon in Water

Monitor Well Sampling with an Electric Submersible Pump

Monitor Well Sampling with a Bladder Pump

Monitor Well Sampling with a Peristaltic Pump

Quality Control Samples for Water Sampling

Completion of Wall and Spring Inventory 
ATTACHMENT 6

SITE INSPECTION CHECKLIST 


\section{SITE INSPECTION CHECKLIST FOR THE LAKEVIEW, OREGON, URANIUM MILL TAILINGS DISPOSAL SITE}

Date of Last Inspection:

Reason for Last Inspection:

Responsible Agency": DOE Grand Junction Projects Office

Address: P.O. Box 2567, Grand Junction, Colorado 81502-2567

Responsible Agency Official:

Inspection Start Date and Time:

Weather Conditions at Site:

Inspection Completion Date and Time:

Chief Inspector:

Organization

Assistant Inspector:

Name Title Organization

\section{A. GENERAL INSTRUCTIONS}

1. All checklist items must be completed and detailed comments made to document the results of the site inspection. The completed checklist is part of the field record of the inspection. Additional pages should be used, as necessary, to ensure that a complete record is made. Attach the additional pages and number all pages upon completion of the inspection.

2. Inspectors are to provide an up-to-date résumé or vitae for inclusion in the inspection report.

3. Any checklist line item marked by an " " that is checked by an inspector must be fully explained or an appropriate reference to previous reports provided. The purpose of this requirement is to provide a written explanation of inspector observations and the inspector's rationale for conclusions and recommendations. Explanations are to be placed on additional attachments and cross-referenced appropriately. Explanations, in addition to narrative, will take the form of sketches, measurements, and annotated site atlas overlays.

4. The site inspection is a walking inspection of the entire site, including the perimeter and sufficient transects to be able to inspect the entire surface and all features specifically described in this checklist. Every monument, site marker, sign, monitoring well, and erosion control marker will be inspected.

\footnotetext{
'Responsibility for alte inspections sesiloned by DOE UMTRA Projoct Office, Albuquerque, to DOE Grand Junction Projects Office, November 6 , 1990. 
5. A set of color print $35-\mathrm{mm}$ photographs is required. Sufficient photographs will be taken to compare to baseline photographs and determine if there are any significant differences in site appearance. In addition, all anomalous features or new features (such as changes in adjacent area land use) are to be photographed. A photo log entry will be made for each photograph taken.

6. Field notes taken to assist in completion of this checklist will become part of the inspection record. No form is specified; the field notes must be legible and in sufficient detail to enable review by succeeding inspectors and the responsible agency.

B. PREPARATION (to be completed prior to site visit)

1. License (includes Long-Term Surveillance and Maintenance Plan) reviewed.

2. Site as-built plans reviewed and base map with copies of the following site atlas overlays obtained:

a. Adjacent off-site features and land use; fences, gates, and signs; access roads and paths.

b. Survey monuments, boundary markers, site markers, aerial photo ground controls, ground photo locations.

c. Monitoring wells, site drainage, diversion channels.

d. Planned inspection transects and vegetation cover.

e. Others.

These overlays will be used to identify site features and record, as appropriate, field data.

3. Previous inspection reports reviewed.

a. Were anomalies or trends in modifying processes detected on previous inspections?

b. Was a Phase II inspection conducted?

c. Was custodial maintenance performed?

d. Was contingency repair work done as a result of the Phase II inspection? 
4. Site custodial maintenance and contingency repair records reviewed.

a. Has site contingency repair resulted in a change from as-built conditions?

b. Are reviewed as-builts available that reflect contingency repair changes?

5. If required, adjacent property entry approval obtained (attach signed access agreement).

6. Aerial photos, if taken since last inspection, reviewed. For each set, enter date taken, scale, and if interpreted.

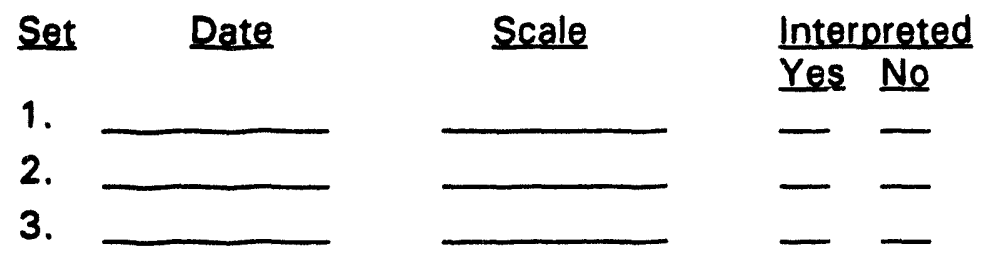

7. Were any of the following suggested by examination of aerial photographs? (If yes, give photo set date and indicate if item noted by interpreter or inspector):
a. Intrusion by man?
b. Intrusion by animals?
c. Channelized erosion on slopes?
d. Change in area drainage?
o. Landslides?
f. Creep on slopes?
g. Obstruction of diversion channels?
h. Bank erosion of diversion channels?
i. Seepage?
j. Cracking? 
k. Change in vegetative cover?

I. Displacement of fences, site markers, boundary markers, or monuments?

m. Change in adjacent land use?

n. Evidence of tailings exposure or transport?

8. From as-builts, or subsequent inspection reports, note distance ano azimuth from designated site location, such as a monument, to adjacent off-site features that could eventually affect integrity of site.

\section{Off-site feature}

Site monument no.

Distance

Azimuth

1.

2.

3.

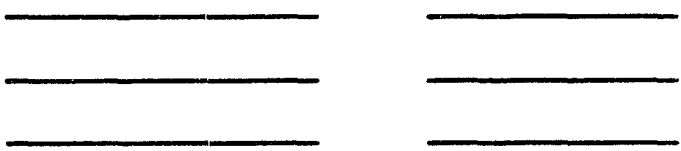

9. Assemble and check out the following equipment, as needed, to conduct inspections:
a. Cameras, film, and miscellaneous support equipment.
b. Binoculars.
c. Tape measure.
d. Optical ranging device.
e. Brunton compass.
f. Photo scale stick.
g. Erasable board.
h. Plant press, plastic bags for vegetation.
i. Keys to locks.
j. Bolt cutters.
k. Hand lens.
I. Clipboard.
m. Others. 


\section{SITE INSPECTION}

1. Adjacent off-site features (within 0.4 meter [0.25 mile] of site boundary)

a. Have there been any changes in use of adjacent areas (grazing, construction, agriculture)?

b. Are there any new roads or trails?

c. Has there been a change in the position of nearby stream channels?

d. Has there been headward erosion of nearby gullies?

e. Are there new drainage channels?

f. Others?

2. Access roads and paths, fences, gates, and signs.

a. Is there a break in the fence?

b. Have any posts been damaged or their anchoring weakened?

c. Is there evidence of erosion or digging beneath the fence?

d. Does the gate show evidence of tampering or damage?

e. Is there any evidence of human intrusion?

f. Is there any evidence of large animal intrusion?

g. Have any signs been damaged or removed? (Number of signs replaced:

h. Are access roads and paths passable?

i. Others? 
3. Monuments and other permanent features.

8. Have the survey or boundary monuments been defaced or disturbed?

b. Have the site markers been disturbed by man or natural processes?

c. Do natural processes threaten the integrity of any monument or site marker?

d. Others?

4. Crest.

a. Is there evidence of uneven settling? (depressions, scarps)

b. Is there cracking?

c. Has the outer cover layer been breached?

d. Is there evidence of erosion?

1) By water? (rills, rivulets)

2) By wind? (pedestal rocks, ripple marks)

e. Is the vegetation cover as described in the as-builts?

f. Is there evidence of animal burrowing?

g. Others?

5. Slopes.

a. Is there evidence of gradual downslope movement (creep)? (terraces, deflection of plants) 
b. Is there cracking?

c. Can depressions or bulges on the slope be seen?

d. Has the outer cover layer been breached?

e. Is there evidence of erosion:

1) By water?

2) By wind?

f. Has water runoff become channelized? (rivulets, gullies)

g. Is there evidence of seepage? (moisture, color, vegetation)

h. Has the vegetation cover changed significantly since the last inspection?

i. Is there evidence of animal burrowing?

j. Is there evidence of deterioration of riprap or gravel cover?

k. Others?

6. Periphery (within site boundaries).

a. Is there evidence of seepage such as wet areas or localized change of vegetation?

b. Is there evidence of sediment transport from the tailings pile by water or wind?

C. Is the vegetative cover as described in the as-builts?

d. Is the drainage as described in the as-builts?

e. Others? Burrowing animals; erosion. 
7. Diversion channels.

a. Is there evidence of bank erosion?

b. Has the integrity of riprap structures been disturbed by people or natural processes?

c. Is there evidence of channel erosion?

d. Is there evidence of sedimentation in the channel?

e. Is the channel obstructed in any way?

f. Is there any evidence that the diversion channels are not performing their function?

g. Others?

8. Photography.

a. Have all photos required by the site atlas photo overlay been taken?

b. Has a photo log sheet been prepared for each roll of film exposed?

c. Number of rolls of film exposed:

d. Others?

9. Monitor wells.

a. Have any monitor wells been disturbed by man or natural processes?

b. Does any natural process threaten the integrity of any monitor well?

c. Are all monitor wells capped and locked?

d. Others? 


\section{FIELD CONCLUSIONS}

1. Is there an imminent hazard to the integrity of the tailings pile? (Immediate report required)

Person

Agency to whom report made:

2. Are more frequent Phase I inspections required?

3. Are existing contingency repair actions satisfactory?

4. Is a Phase II inspection required?

5. Is a contingency report or custodial maintenance required?

6. Rationale for field conclusions are documented as the text of this report.

\section{E. CERTIFICATION}

I have conducted a prelicensing inspection of the Lakeview (Collins Ranch) uranium mill tailings site in accordance with the procedures of the license (includes the site surveillance plan) as recorded on this checklist, attached sheets, field notes, photo log sheets, and photos.

Chief Inspector's Signature

Title
Printed Name

Date

(Stamp or Seal) 


\section{ATTACHMENT 7}

AGENCY NOTIFICATION AGREEMENTS

(Response to NRC Comment \# 22) 


\section{MIS/UMT/0892-0044}

Albert R. Chernoff

UMTRA Project Manlager

U.S. Department of Energy

Uranium Mill Tailings Remedial Action

Project Office

5301 Central Avenue, N.E., Suite 1720

Albuquerque, New Mexico 87108

Attention: Steve Hamp

Dear Mr. Chernotf:

This letter is to concur with U.S. Department of Energy (DOE) request for notification as set forth in the DOE's letter of $8-13,1992$. As requested in your letter, this office will contact the DOE's Grand Junction Projects Office at (303) 248-6070 if any unusual event or anomaly is observed or reported at the Lakeview disposal site. 
Sincerely,

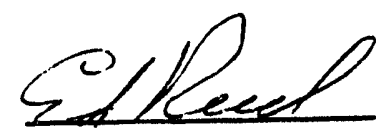

Name

Sherese

Title

Lake County Sheriff's Department

513 Center Street

Lake County Courthouse

Lakeview, OR 97630

\section{Enclosures}

cc: CJones, GJPO

Jirgona, GJPO

SHamp, UMTRA

FBosiljevac

MDay, TAC

MBLeaf, TAC 


\title{
Department of Energy \\ Albuquerque Field Office \\ P.O. Box 5400
}

Albuquerque, New Mexico 87185-5400

\begin{abstract}
Albert R. Chernoff
UMTRA Project Manager

U.S. Department of Energy

Albuquerque Operations Office

P.O. Box 5400
\end{abstract}

Albuquerque, NM 87185-5400

Dear Mr. Chernoff:

This letter is in response to the U.S. Department of Energy (DOE) request for notification as set forth in the DOE's letter. This office will contact the DOE Grand Junction Projects Office at (303) 248-6070 if flash flood or tormado warnings are issued for Lake County, Oregon.

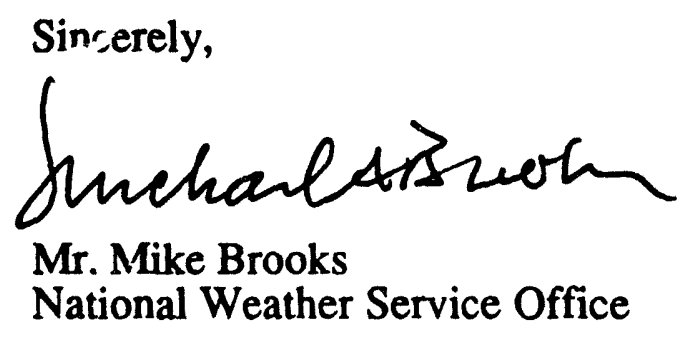




$$
\text { MIS.|LITT|OL94/0023 }
$$

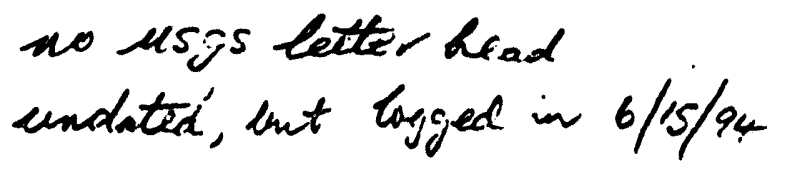

Clinton C. Smythe

Engineering and Construction Group Leader

Uranium Mill Tailings Remedial Action

Project Office

2155 Louisiana NE, Suite 4,000

Albuquerque, NM 87110

Dear Mr. Smythe:

This letter is to confirm that the DOE Grand Junction Projects Office (24-hour phone line, (303) 248-6070 has been added to our notification list for the occurrence of earthquakes near the following locations:

\begin{tabular}{|l|l|l|}
\hline Disposal Site & Latitude & Longitude \\
\hline COLORADO & & \\
\hline Durango (Bodo Canyon) & N37.15 & W107.90 \\
\hline Grand Junction & N38.91 & W108.32 \\
\hline Gunnison (Landfill) & N38.51 & W106.85 \\
\hline Maybell & N40.55 & W107.99 \\
\hline Naturita (Dry Flats) & N38.21 & W108.60 \\
\hline Rifle (Estes Gulch) & N39.60 & W107.82 \\
\hline Slick Rock (Burro Canyon) & N38.05 & W108.87 \\
\hline DAHO & & \\
\hline Lowman & N44.16 & W115.61 \\
\hline NEW MEXICO & & \\
\hline Ambrosia Lake & N35.41 & W107.80 \\
\hline NORTHDAKOTA & & \\
\hline Bowman & N46.23 & W103.55 \\
\hline OREGON & & \\
\hline Lakeview (Collins Ranch) & N42.2 & W120.3 \\
\hline PENNSYLVANIA & & \\
\hline Canonsburg & N40.26 & W80.25 \\
\hline Burrell VP & N40.62 & W79.65 \\
\hline TEXAS & & \\
\hline Falls City & N28.91 & W98.13 \\
\hline UTAH & & \\
\hline Mexican Hat & N37.10 & W109.85 \\
\hline Salt Lake City (Clive) & N40.69 & W113.11 \\
\hline
\end{tabular}


Clinton C. Smythe

$-2-$

We have entered the following selection criteria into our notification program:

1. Any earthquake of magnitude 3.0 or greater, within 0.3 degrees (about 20 miles) of any site shown above, or

2. Any earthquake of magnitude 5.0 or greater, within 1.0 degrees (about 70 miles) of any site shown above.

Sincerely,

Duce w. Preserve

Bruce Presgrave

U.S. Geological Survey

National Earthquake Information Center

P.O. Box 25046

Mail Stop 967

Denver Federal Center

Denver, Colorado 80225

Please address future comespondonce to Stuart Koyanagi at the above address. I have moved to a different project.

Thank you + best regards,

Dunce Prugrave 
Plate 1

LAKEVIEW (COLLINS RANCH) DISPOSAL VICINITY SITE MAP 
PLATE 2

LAKEVIEW (COLLINS RANCH) DISPOSAL SITE FINAL TOPOGRAPHIC MAP 

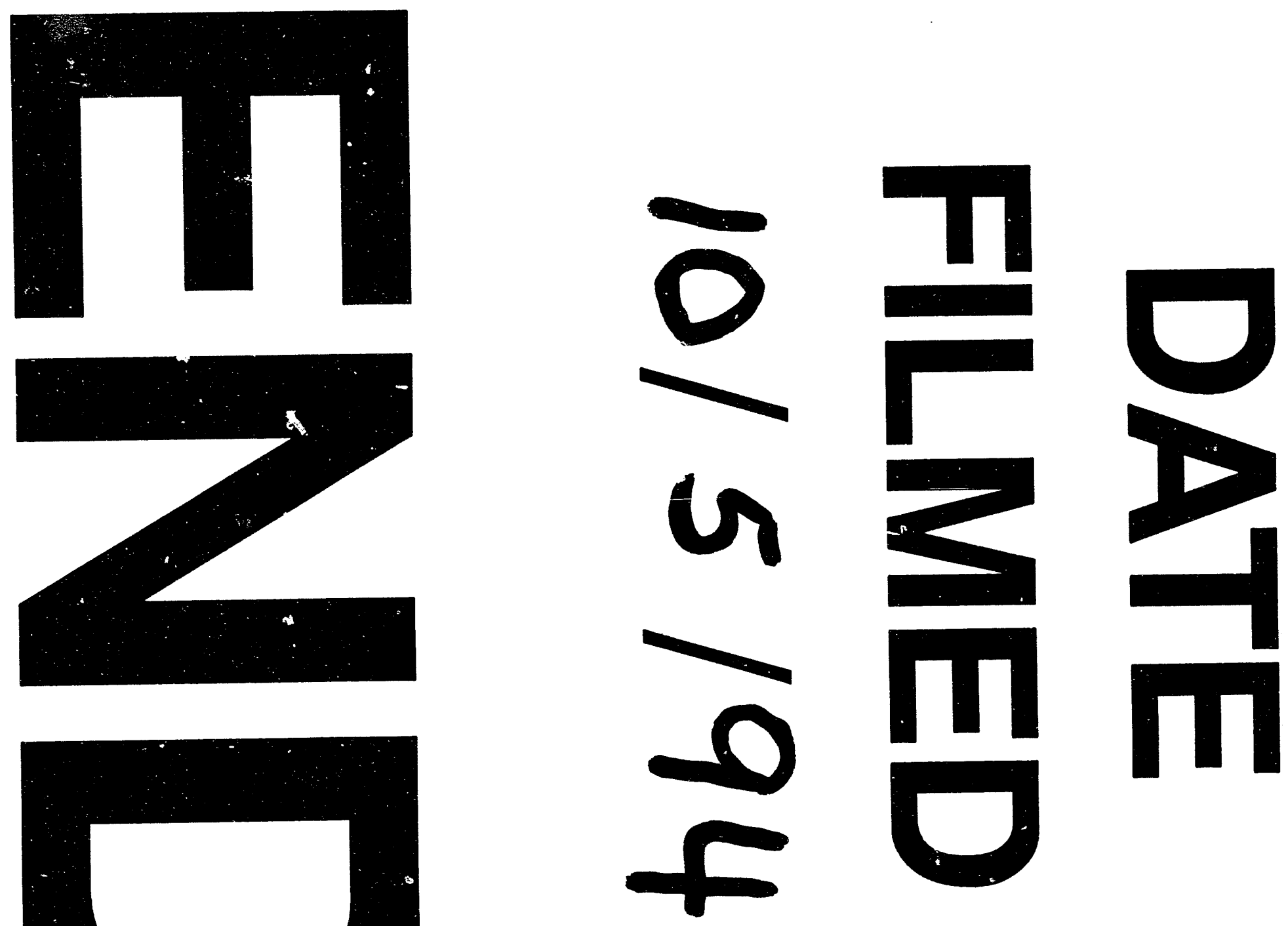
